Universidade de Brasília

Centro de Excelência em Turismo

\title{
ECOTURISMO E A QUESTÃO DO DESENVOLVIMENTO SUSTENTÁVEL EM SÃO JOÃO D’ ALIANÇA - NORDESTE GOIANO
}

\author{
Elias Begnini \\ Carlos José Rodrigues Silva \\ Monografia apresentada ao Centro de \\ Excelência em Turismo da Universidade. de \\ Brasília como requisito parcial para a \\ obtenção do certificado de Especialista em \\ Formação de Professores e Pesquisadores \\ em Turismo e Hospitalidade.
}


UNIVERSIDADE DE BRASÍLIA

Centro de Excelência em Turismo

Curso de Especialização em Formação de Professores e Pesquisadores em Turismo e Hospitalidade

\title{
ECOTURISMO E A QUESTÃO DO DESENVOLVIMENTO SUSTENTÁVEL EM SÃO JOÃO D’ ALIANÇA - NORDESTE GOIANO
}

\author{
Elias Begnini
}

Carlos José Rodrigues Silva, Msc.

Brasília, DF, 04 de dezembro de 2003 
Begnini, Elias

Ecoturismo e a Questão do Desenvolvimento Sustentável em São João d' Aliança - Nordeste Goiano / Elias Begnini xiii, 127 pág.: il.

Monografia (especialização) - Universidade de Brasília. Centro de Excelência em Turismo. Brasília, 2003.

Área de concentração: Ecoturismo

Orientador: Carlos José Rodrigues Silva

1. Ecoturismo 2. Desenvolvimento Sustentável 3. São João d' Aliança - Monografia 


\section{ELIAS BEGNINI}

Ecoturismo e a Questão do Desenvolvimento Sustentável em São João D’ Aliança Nordeste Goiano / Elias Begnini.

Comissão Avaliadora

Prof. Msc. Carlos José Rodrigues Silva

Prof. Msc. Raquel Assunção Botello

Brasília, DF, 04, dezembro, 2003. 
Dedico este trabalho a todos aqueles que sonham por uma vida mais digna, que lutam por uma distribuição de renda mais justa em uma sociedade tão sofrida como a brasileira; que tenham consciência de seu importante papel social a ser desempenhado, que sejam mais solidários para com nossos próximos de hoje, e que primem pelo comprometimento pessoal pela melhoria das condições de vida das gerações futuras. Portanto, dedico este trabalho para a comunidade de São João d’ Aliança - Goiás, pela sua vontade de lutar pelo desenvolvimento de seu município, pelo seu respeito pelas diferenças pessoais, pelo comprometimento com a preservação do meio ambiente, por seu espírito de trabalho em equipe e, por seu sentimento de colaboração e amizade. 
Agradeço em especial a Deus, por dar-me forças nos momentos difíceis, por encorajar-me a lutar por situações melhores quando os problemas parecem ser insolúveis e, por ensinar-me que o bom da vida é saber que sempre há algo novo a se aprender, por colocar pessoas maravilhosas no meu caminho, como meus pais, meus irmãos, minha companheira para toda hora Dailani, meus amigos, professores e colegas de especialização e meu orientador Carlos José Rodrigues que muito me ajudou se mostrando sempre disposto a ensinar. 
"Não se pode governar uma sociedade ou enfrentar seus problemas se as pessoas não forem responsáveis pelo que fazem”.

John Lennon. 


\section{RESUMO}

Este estudo tem como objetivo levantar e analisar o potencial turístico do município de São João d' Aliança (GO), localizado na Chapada dos Veadeiros, através do inventário de seus atrativos naturais, históricos e culturais, das facilidades turísticas e da infraestrutura. Além disso, procura captar a percepção dos líderes municipais quanto à contribuição do ecoturismo desta localidade para o desenvolvimento municipal. O método básico utilizado para realização do trabalho foi a aplicação de entrevistas, o registro fotográfico, a participação em reuniões comunitárias e a consulta de materiais bibliográficos. Entre os resultados alcançados destacam-se: (i) o produto ecoturístico do município analisado, em fase preliminar de descobertas; (ii) as condições socioeconômicas, a infra-estrutura e a estrutura de serviços prestados que ainda dificultam o desenvolvimento do ecoturismo; (iii) a participação comunitária efetiva na elaboração de um planejamento em ecoturismo. O mundo moderno cindiu o tempo e o espaço em movimentos e cenários de trabalho e de lazer. O turismo aparece como um nova alternativa de descanso para os trabalhadores e, o patrimônio natural é um dos principais atrativos turísticos no mundo. O ecoturismo constitui-se em uma alternativa para suprir as necessidades do público constituído por pessoas em busca de contato com áreas naturais. O planejamento ecoturístico é vital para se maximize o aproveitamento das experiências vividas pelos visitantes e, ao mesmo tempo, minimize os impactos ambientais desse uso sobre o referido território.

Palavras Chaves: Ecoturismo; Desenvolvimento Sustentável; São João d’ Aliança. 


\begin{abstract}
The aim of this study is to achieve a survey on the touristic potential of São João d' Aliança in Goiás, located in the region of Chapada dos Veadeiros, and to analyze the collected data of natural, historic and cultural information, touristic places and of infrastruture. Moreover, it tries to capture the perception of the municipal leaders towards the contribution of this town to ecotourism. The survey was accomplished by means of interviews, pictures, community meetings and bibliography consulting. Among the results achieved it is worth mentioning: (i) the ecotouristic production of the analized town, in a preliminary stage ; (ii) the socialeconomic conditions, the infrastructure and the offered services that continue to raise difficulties towards the ecotourism development; and (iii) the community participation in the ecotourism planning. The modern world divided time and space in moments and scenaries of work and leisure. The tourism appears as a new alternative for workers' leisure. The natural patrimony is one of the main tourist places in the world. The ecotourism is a suitable alternative to supply the needs of the population which is formed by people in search of nature contact. The ecotouristic planning is vital to maximize the visitors experience, and, at the same time, minimize the environmental impacts of the use of this territory.
\end{abstract}

Keywords: Ecotourism; Sustentable Development, São João d’Aliança 
INTRODUÇÃO .01

1 CONCEITOS FUNDAMENTAIS DE TURISMO.............................................05

2 REVISÃO BIBLIOGRÁFICA ………………………..................................10

A) DESENVOLVIMENTO SUSTENTÁVEL_........................................................ 10

A.1) Características do Desenvolvimento Local Integrado Sustentável......... 18

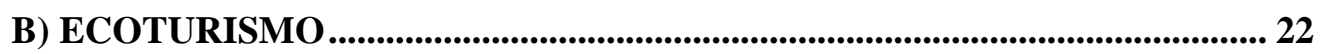

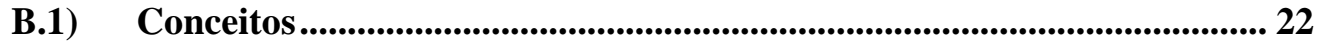

B.2) Sustentabilidade do Ecoturismo ……............................................................. 26

B.3) Ambientalismo X Ecoturismo .......................................................................... 27

C) CARACTERIZAÇÃO GEOGRÁFICA DE SÃO JOÃO D’ALIANÇA........ 31

C.1) Localização Geográfica - Goiás................................................................. 31

C.2) Localização Geográfica - Nordeste Goiano.............................................. 32

C.3) Microrregiões do Nordeste Goiano ................................................................ 32

C.4) Microrregião da Chapada dos Veadeiros ............................................... 34

C.5) Município de São João d'Aliança ................................................................. 36

C.5.1) Estatísticas do Município .......................................................................... 45

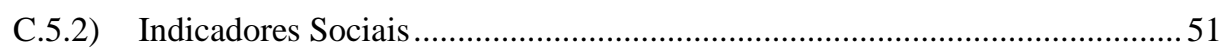

C.5.3) Organização Social.................................................................................. 58

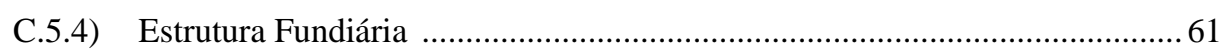

C.6) Infra-estrutura ................................................................................................... 65

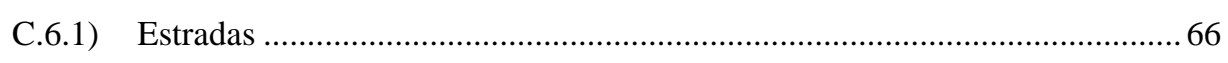

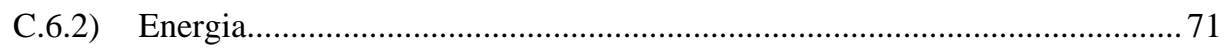

C.6.3) Saneamento Básico..................................................................................... 73

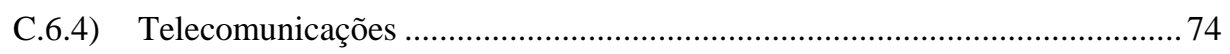

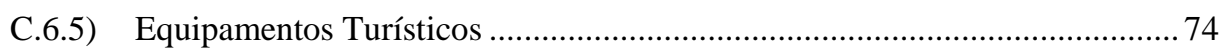




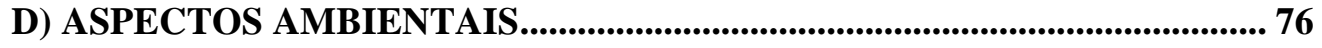

D.1) Panorama da Proteção Ambiental no Brasil ................................................. 76

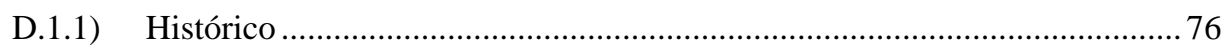

D.2) A Reserva da Biosfera do Cerrado Goyaz ................................................... 77

D.2.1) Aspectos Físico-Ambientais ............................................................................ 79

D.2.2) Aspectos Econômico-Ambientais.................................................................... 79

D.2.3) Aspectos Sócio-Ambientais ...................................................................... 79

D.2.4) Aspectos Científico-Ambientais ................................................................ 80

D.3) As Zonas Núcleo da Reserva da Biosfera do Cerrado Goyaz ................. 80

D.3.1.) Parque Nacional da Chapada dos Veadeiros ................................................... 80

D.3.2.) APA- Áreas de Proteção Ambiental ............................................................. 81

D.4) Potencial Turístico da Região .......................................................................... 81

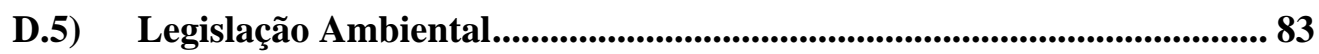

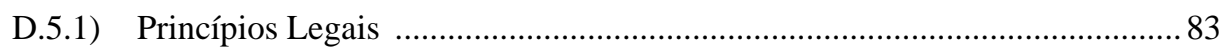

D.5.2) Aplicação das Normas Ambientais ................................................................. 84

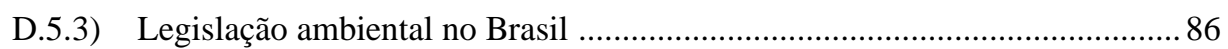

E) PLANEJAMENTO EM ECOTURISMO E O DESENVOLVMENTO ....... 88

3 METODOLOGIA.................................................................................................97

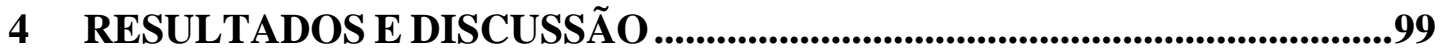

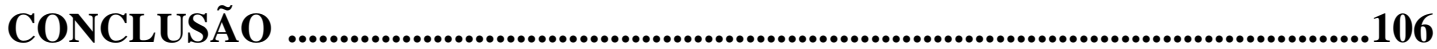

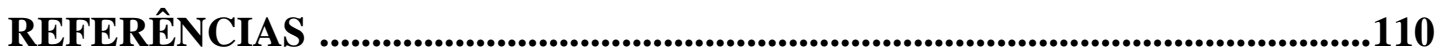

ANEXOS

Anexo A Fotos dos Atrativos Ecoturísticos de São João D’ Aliança - GO ...... 113

Anexo B Roteiro para Entrevista em São João d'Aliança - GO ......................... 118

Anexo C Prospecto de Inauguraçãoda Sede - Acordo Cerrado ......................... 119

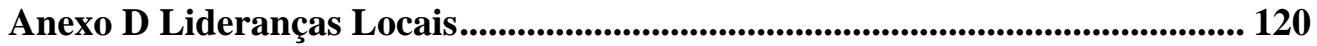

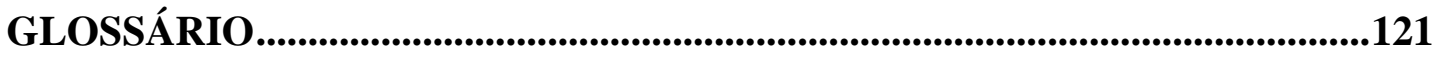




\section{ÍNDICE DE TABELAS}

TABELA 01 - COMPOSIÇÃO DA REGIÃO NORDESTE DO ESTADO DE GOIÁS (2000) ………………………..............33

TABELA 02 - EVOLUÇÃO DAS POPULAÇÕES URBANA E RURAL - GOIÁS, BRASIL ..................................................... 35

TABELA 03 - VARIAÇÃO PERCENTUAL DA POPULAÇÃO DA CHAPADA DOS VEADEIROS $(1980-2001)$.....................39

TABELA 04 - PARTICIPAÇÃO POPULACIONAL URBANA E RURAL (\%): CHAPADA DOS VEADEIROS (1980-2000) .. 40

TABELA 05 - VARIAÇÃO POPULACIONAL URBANA E RURAL (\%): CHAPADA DOS VEADEIROS (1980-2000) ...........42

TABELA 06 - DENSIDADE DEMOGRÁFICA - REGIÃO NORDESTE DO ESTADO DE GOIÁS (2001)................................44

TABELA 07 - MICRORREGIÃO CHAPADA DOS VEADEIROS: PRODUÇÃO ANIMAL (2000).......................................... 45

TABELA 08 - MICRORREGIÃO CHAPADA DOS VEADEIROS: PRODUÇÃO VEGETAL GRÃOS (2001) ............................46

TABELA 09 - CHAPADA DOS VEADEIROS: PRODUÇÃO VEGETAL FRUTAS E CANA DE AÇÚCAR (2001) ...................46

TABELA 10 - GOIÁS: EFETIVO DE BOVINOS, SUÍNOS E AVES POR MICRORREGIÃO (2000) …………….................48

TABELA 11 - EFETIVO BOVINO - CHAPADA DOS VEADEIROS ......................................................................... 49

TABELA 12 - PRODUÇÃO AGRÍCOLA: DÉFICIT DE PRODUTIVIDADE (2001) …………........................................49

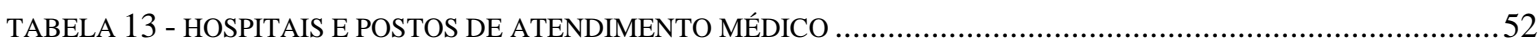

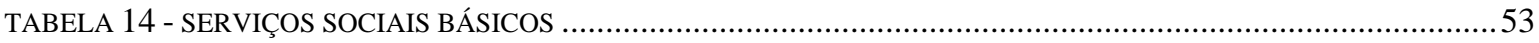

TABELA 15 - PERFIL DA MICRORREGIÃO CHAPADA DOS VEADEIROS - INDICADORES SOCIAIS (1991)....................54

TABELA 16 - ÍNDICE DE DESENVOLVIMENTO HUMANO: EVOLUÇÃO CHAPADA DOS VEADEIROS (1991-2000)......59

TABELA 17 - DESEQUILÍBRIO REGIONAL: MICRORREGIÕES DO ESTADO DE GOIÁS (IDH 2000) …...........................60

TABELA 18 - POLÍTICAS E PROGRAMAS DE GERAÇÃO DE EMPREGO, PRODUÇÃO E RENDA....................................60

TABELA 19 - DISTRIBUIÇÃO DE IMÓVEIS RURAIS: CHAPADA DOS VEADEIROS ......................................................61

TABELA 20 - ASSENTAMENTOS E FAMÍLIAS ASSENTADAS: INCRA (1999)............................................................. 62

TABELA 21 - INDICADORES CADASTRAIS DE IMÓVEIS RURAIS DA CHAPADA DOS VEADEIROS (1997) ..................63

TABELA 22 - DISTRIBUIÇÃO DA MALHA FUNDIÁRIA DA CHAPADA DOS VEADEIROS .............................................64

TABELA 23 - ESTRUTURA FUNDIÁRIA - UTILIZAÇÃO DOS SOLOS (1996) ………………………………………...64

TABELA 24 - PREVISÃO E EXECUÇÃO DE LIGAÇÕES: CHAPADA DOS VEADEIROS (2002) ……………………….... 72

TABELA 25 - CONSUMO DE ENERGIA ELÉTRICA: CHAPADA DOS VEADEIROS (2001) .............................................73 


\section{ÍNDICE DE FIGURAS}

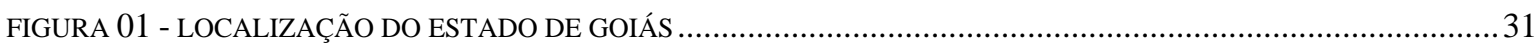

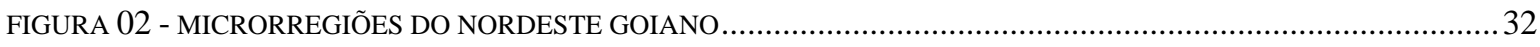

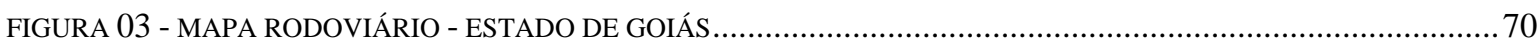

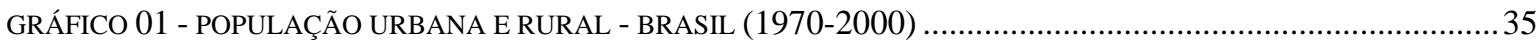

GRÁFICO 02 - POPULAÇÃO URBANA E RURAL - GOIÁS (1970-2000)................................................................... 35

GRÁFICO 03 - PREVISÃO E EXECUÇÃO DE LIGAÇÕES ELÉTRICAS- CHAPADA DOS VEADEIROS (2002) ...................72

GRÁFICO 04 - CONSUMO DE ENERGIA POR CATEGORIA - REGIÃO DA CHAPADA DOS VEADEIROS (2001) ...............74 


\section{ABREVIATURAS}

ACIAGA Associação Comercial de São João d’ Aliança

AGEMA Associação de Guias de São João d’ Aliança

AGETUR Agência Goiana de Turismo

ALIART Associação de Artesãos de São João d’ Aliança

ANEEL Agência Nacional de Energia Elétrica APA Área de Proteção Ambiental

CELG Companhia Energética de Goiás

CET/UnB Centro de Excelência em Turismo da Universidade de Brasília

CMMDA .Comissão Mundial Sobre Meio Ambiente e Desenvolvimento

COMTUR Conselho Municipal de Turismo

CONAMA Conselho Nacional do Meio Ambiente

$\mathrm{CV}$ Chapada dos Veadeiros

DLIS Desenvolvimento Local Integrado e Sustentável ed. Editora EIA Estudo de Impacto Ambiental EMBRATUR Instituto Brasileiro de Turismo

GO Estado de Goiás IBAMA Instituto Brasileiros do Meio Ambiente e dos Recursos Renováveis IBGE Instituto Brasileiro de Geografia e Estatística 
IDH Índice de Desenvolvimento Humano

IEB Instituto de Ecoturismo do Brasil

IICA Instituto Interamericano de Cooperação para a Agricultura INCRA Instituto Nacional de Colonização e Reforma Agrária IUCN. União Internacional para a Conservação da Natureza MW Megawatt MWh Megawatt/hora

OCDE Organização de Cooperação e Desenvolvimento Econômico

OMS Organização Mundial de Saúde

OMT Organização Mundial de Turismo ONG Organização Não Governamental ONU Organização das Nações Unidas

OSCIP Organização da Sociedade Civil de Interesse Público PNMT Programa Nacional de Municipalização do Turismo

RIMA Relatório de Impacto Ambiental

RPPN Reserva Particular do Patrimônio Natural SEPIN Superintendência de Estatística, Pesquisa e Informação SEPLAN Secretaria de Planejamento e Desenvolvimento do Estado de Goiás

UNESCO Organização das Nações Unidas para Educação, Ciência e Cultura WWF World Wide Fund for Nature (Fundação Mundial para a Natureza) 


\section{INTRODUÇÃO}

Uma das maiores discussões da atualidade é a relação entre o modelo de desenvolvimento econômico vigente e a questão do equilíbrio ecológico. Os benefícios provenientes das inovações tecnológicas e do crescimento econômico estão intrinsecamente - ligados aos malefícios da falta de capacidade do meio ambiente de acompanhar e suportar a exploração desenfreada de seus recursos pelo sistema econômico vigente. O paradoxo deste questionamento está nas conseqüências do esgotamento dos recursos naturais, provocado pela demanda advinda das necessidades humanas ilimitadas.

Em um período de longo prazo, a degradação ambiental reduz, a amplitude dos benefícios imediatos provenientes do consumo desenfreado. Um dos resultados deste fenômeno é o desequilíbrio ecológico que vem acarretando problemas sociais, econômicos, culturais e políticos. Certos recursos estão desaparecendo do planeta, o que os torna menos acessíveis a todos que anseiam adquiri-los. Este fato cria problemas de desigualdades sociais que envolvem desde a questão de disputa por um status social mais elevado à concentração extrema de renda por pequenas parcelas privilegiadas da população.

Observado este contexto, percebe-se que todas as nações - desenvolvidas ou não vêm enfrentando este problema. No entanto, pode-se identificar que esta é uma situação com efeitos específicos mais avassaladores em países com baixo grau de desenvolvimento que devem, por isso, adotar um novo modelo de desenvolvimento socioeconômico, com o intuito de evitar que seus recursos naturais e a sua biodiversidade desapareçam, como ocorreu em vários países desenvolvidos.

A construção de um modelo de produção e distribuição de renda para países com recursos de ordem financeira, humana e tecnológica escassos, deve ser encarada como um desafio para a comunidade internacional, visto que os efeitos da devastação ambiental geram conseqüências drásticas para todos os países do mundo. Portanto, os países em desenvolvimento - excluídos da maioria dos benefícios do modelo de desenvolvimento socioeconômico atual - devem utilizar-se do conceito de sustentabilidade para a criação de um novo modelo de desenvolvimento condizente com suas realidades atuais. 
No Brasil, o agravamento do cenário social, resultante do elevado nível de desemprego, da degradação ambiental e da desordenada ocupação territorial, resulta em um quadro de disparidades que tende a se acentuar, caso nada seja feito para reduzir-se o efeito devastador de uma sociedade injusta e concentradora de riquezas. A agropecuária e a indústria, duas das principais atividades econômicas brasileiras, são reconhecidas como fontes geradoras de impactos ambientais de amplitude elevada. Neste fato está a percepção da necessidade de diversificação da economia nacional, com a implantação de atividades condizentes com a chamada “indústria limpa”, fenômeno que vem ocorrendo nas regiões mais prósperas do globo terrestre.

O objeto de estudo do presente trabalho está inserido nesse contexto. A problemática da falta de opções aos cidadãos de municípios de menor dinamismo econômico, faz que os mesmos não tenham condições de permanecer em seus locais de origem. A substituição do modelo socioeconômico - que se encontra ultrapassado - pode permitir a redução do processo de êxodo rural e dos problemas resultantes desse fenômeno provocado pela falta de oportunidades - como violência urbana, exclusão social, desagregação familiar, ocupação desordenada do espaço urbano, subemprego, dentre outros.

Um modelo socioeconômico mais justo pode desenvolver uma sociedade baseada em relações de trabalho e emprego, pautado na cooperação e na cidadania. Um novo objetivo passaria a integrar este modelo - a obtenção da garantia de níveis satisfatórios de qualidade de vida ao trabalhador e à sua família. O emprego e a renda são fatores necessários para que as pessoas permaneçam em suas localidades de origem.

O turismo, em seu sentido econômico e social, é uma das poucas atividades que consegue gerar um considerável aumento no nível de emprego - direto e indireto - e renda para pessoas de diferentes faixas etárias nas mais diversas localidades onde é implantado. Portanto, o turismo responsável torna-se um mecanismo redutor de dispersão da população de localidades menos favorecidas em direção aos grandes centros.

A escolha de São João d'Aliança como local de interesse do objeto de estudo, está na sua similaridade com os milhares de outros municípios brasileiros que possuem problemas similares de distribuição de renda, mortalidade infantil elevada, condições sanitárias precárias, problemas habitacionais, terras ocupadas sem títulos de propriedade e, baixa oferta de energia elétrica, fatores que contribuem e retroalimentam um ciclo vicioso no qual se estabelece a máxima da exclusão social que se materializa por toda uma região. 
O presente trabalho mostra que o baixo nível do Índice de Desenvolvimento Humano (IDH), o reduzido capital social, a falta de capacitação e a baixa qualificação profissional da maioria dos habitantes de um município como em um período de longo prazo São João d'Aliança complementam o rol de semelhanças com outros municípios do país. As causas que influenciam estes fatores são complexas. Envolvem desde desequilíbrios econômicos, políticos, sociais e culturais até deficiências institucionais que não permitam a consolidação da cidadania. O ajuste destes fatores deve ser feito para que a localidade possa desenvolver-se de forma sustentável. Um modo de realizar-se os ajustes necessários é a seleção de atividades econômicas que dinamizem a economia local, com distribuição de renda e, que não prejudiquem a maior riqueza da região - sua natureza.

O ecoturismo é uma das atividades econômicas que possui os pré-requisitos mencionados, constituindo-se em uma oportunidade para a redução dos efeitos negativos gerados pelo modelo socioeconômico vigente. Com isso, objetivo final deste trabalho é saber quais são as reais possibilidades de se potencializar esta atividade econômica com a implementação de uma política municipal de ecoturismo em São João d’Aliança. Outro ponto a ser observado é que - apesar da similaridade com outros municípios brasileiros no quesito problemas socioeconômicos - São João possui um potencial ecoturístico único. Reconhecido pela quantidade e qualidade de suas belezas naturais, pela cultura única de seu povo, pelo uso de frutos típicos da região na gastronomia local e pela sua localização privilegiada, constitui-se em uma das mais belas regiões preservadas de cerrado do país ainda desconhecida da maioria dos ecoturistas, sejam brasileiros e estrangeiros.

A apropriada implantação da atividade ecoturística nesta localidade poderá resultar no aumento expressivo da renda de seus habitantes, com reflexos na educação e na saúde, itens de extrema relevância para a o aumento do Índice de Desenvolvimento Humano (IDH) local, além de permitir a continuidade da preservação ambiental, componente indispensável para o conceito de sustentabilidade - assunto é tratado no segundo capítulo deste trabalho. A conscientização e o envolvimento profundo da população em todo o processo de implantação do ecoturismo no município são indispensáveis para o seu êxito. A comunidade de São João d'Aliança deve participar desde a etapa de planejamento municipal do ecoturismo, até a fase do usufruto dos resultados econômicos obtidos.

A monografia está segmentada em quatro capítulos. O primeiro trata dos conceitos fundamentais do Turismo, com o intuito de contextualizar o leitor e definir a linha 
conceitual de desenvolvimento no que tange à utilização atual do termo. O capítulo 2 refere-se à revisão bibliográfica que cuida da questão do Desenvolvimento Sustentável, da definição de Ecoturismo, da caracterização geográfica do município de São João d’Aliança e da região no qual está inserido, dos aspectos ambientais regionais e da participação municipal neste contexto, concluindo o capítulo com a discussão sobre o Planejamento em Ecoturismo como fator de Desenvolvimento Sustentável Municipal. O capítulo 3, consiste na metodologia aplicada para a comprovação dos resultados expostos no capítulo 4, pelo qual chegou-se à conclusão do presente trabalho, com a análise dos dados coletados por instrumentos de pesquisa como a observação participativa, a entrevista e a análise dos documentos disponibilizados pelas repartições públicas do Estado de Goiás.

O objeto da monografia consiste na aplicação de entrevistas, na análise de documentos governamentais e na observação participativa, com o propósito de analisar o nível de conscientização das lideranças locais quanto a necessidade de implementação de um planejamento em ecoturismo em prol da concretização do potencial desta atividade em São João d’Aliança no intuito de alavancar o desenvolvimento sustentável local.

Quanto a metodologia utilizada, o levantamento e a análise de dados provenientes de documentos disponibilizados por repartições públicas estaduais foram realizados com o intuito de se verificar o potencial turístico considerando-se a realidade socioeconômica, política, cultural e ambiental do município. A observação participativa em reuniões comunitárias sobre desenvolvimento municipal permitiu ao pesquisador perceber a relevância da força das opiniões das lideranças locais no direcionamento das ações comunitárias em um ente federativo de pequeno porte. Esta influência surte efeitos consideráveis em uma política de desenvolvimento municipal do tipo participativo. Em suma,. consiste em um poder paralelo ao poder público municipal. A entrevista consistiu na verificação das opiniões formadas das lideranças comunitárias em relação aos temas de preservação ambiental, desenvolvimento sustentável e ecoturismo no município.

O objetivo principal do trabalho é potencializar o ecoturismo no município de São João d'Aliança, ente federativo componente da região Nordeste do Estado de Goiás, mais precisamente na microrregião da Chapada dos Veadeiros. Os objetivos secundários estão na discussão do tema ecoturismo e integração regional como fatores de desenvolvimento sustentável em municípios considerados “áreas prioritárias de preservação ambiental” e na divulgação de São João d’ Aliança como um novo pólo de ecoturismo no Estado de Goiás. 


\section{CONCEITOS FUNDAMENTAIS DE TURISMO}

O turismo é uma atividade humana de alcance elevado, permeando desde a área social até os campos cultural, econômico, ecológico e político. Por isso é detentora de várias definições, não se chegando propriamente a um consenso de qual seja a melhor ou a mais apropriada para uma utilização generalizada ou universal. Visto que há várias escolas e existem tendências diversas que influenciam a formação do conceito deste ramo das ciências sociais, pode-se perceber que há uma considerável quantidade de variáveis que influenciam a construção desta área do conhecimento.

Uma das dificuldades em se definir o que é o turismo está na compreensão da interdisciplinariedade, uma de suas principais características. Esta característica inerente ao turismo envolve uma variedade surpreendente de ciências e de disciplinas que buscam explicar a natureza desta área, o objeto de estudo e os componentes essenciais e secundários que formam o turismo, que é considerado um fenômeno social complexo e diversificado. Este fenômeno está inserido em um amplo contexto, a sociedade industrial. Portanto, pode ser classificado por meio dos mais diversos critérios que influenciam este tipo de sociedade.

O universo do turismo é o lazer. O turismo é uma parte deste todo, sendo que o lazer constitui-se em todas as atividades desenvolvidas fora do sistema produtivo (trabalho), das obrigações sociais, religiosas e familiares. Portanto, o turismo é contextualizado dentro do conceito de lazer. Segundo Beni (2001, pág. 34) "há três tendências para a definição de Turismo: a econômica, a técnica e a holística”.

O conceito de turismo gerado no universo holístico envolve atividades ligadas às trocas de experiências e de informações entre as pessoas, sendo esta uma abordagem mais abrangente do que as tendências de ordem simplesmente econômica e técnica. $\mathrm{Na}$ abordagem técnica são considerados apenas os aspectos de viabilidade mecanicista, desconsiderando os principais fatores humanos da atividade. A limitação na abordagem econômica está na falta de percepção de importantes conseqüências sociais, exagerando o foco sobre os elementos de ordem econômica. 
O turismo é algo mais abrangente do que uma atividade de ordem simplesmente econômica ou técnica. É considerado um tipo de atividade humana intencional que serve como meio de comunicação e de elo de interação entre os povos, tanto dentro como fora de um país. Envolve o deslocamento temporário de pessoas para outras regiões ou países visando a satisfação de outras necessidades que não a de atividades remuneradas. Pode-se dizer, em resumo, que, de acordo com Trigo (2002, p. 11-12), “qualquer viagem temporária com duração superior a vinte e quatro horas é turismo e que as viagens que não superem esta marca, são conhecidas pela nomenclatura excursões”.

Segundo Fuster, entre as várias definições de Turismo pode ser citado o seguinte:

A primeira definição conhecida de Turismo é a do economista austríaco Hermann von Scheillenzee Schattenhofen (1911) de que o Turismo é o conceito que compreende todos os processos, especialmente os econômicos, que se manifestam na chegada, na permanência e na saída do turista de um determinado município, país ou estado.

(Fuster, 1974, pág.24)

De acordo com Andrade (1998, pág. 34) surgem em 1929 na Alemanha definições que apresentaram posições uniformes na chamada "escola berlinesa”, iniciando a fase moderna dos estudos sobre turismo.

Para Glücksmann (1929, pág. 40) “o turismo é considerado um vencimento de espaço por pessoas que vão para um local no qual não têm residência fixa”. Esta definição foi refeita em 1935 pelo mesmo autor. Ainda segundo Glücksmann (1935; p.43) “quem interpreta o turismo como um problema de transporte confunde este com tráfego de turistas”. De acordo com Schwink (1930, pág. 10) “o turismo é o movimento de pessoas que abandonam temporariamente o lugar de residência permanente, por qualquer motivo relacionado com o espírito, o corpo ou a profissão”.

Conforme Benscheidt (1934, pág. 3) “o fenômeno do Turismo consiste no conjunto de relações pacíficas e esporádicas entre os viajantes que visitam um local por motivos não profissionais e os naturais deste lugar”, desvinculando de seu conceito o interesse bélico de espionagem e os interesses comerciais dos empresários da época. 
Na definição de turismo defendida por Josef Stradner percebe-se a presença do componente renda ou status como fator constituinte do termo turismo. Em sua definição Stradner afirma que:

O turismo é o tráfego de viajantes de luxo (aqueles que têm condução própria) que se detém num local fora do seu lugar fixo de residência e com sua presença naquele país não perseguem nenhum propósito econômico, mas buscam a satisfação de uma necessidade de luxo.

(Stradner, 1905, pág. 17)

Segundo Borman (1930, pág. 10) “o turismo é o conjunto de viagens cujo objeto é o prazer ou os motivos comerciais, ou os profissionais, ou outros análogos e, durante os quais a ausência da residência habitual é temporária. Não são incluídas em turismo as viagens realizadas para ir ao local de trabalho”.

Em 1929 em sua definição de Turismo Morgenroth propõe que o turismo é o:

Tráfego de pessoas que se afastam temporariamente do seu lugar fixo de residência para deter-se em outro local com o objetivo de satisfazer suas necessidades vitais e de cultura ou para realizar desejos de diversas índoles, unicamente como consumidores de bens econômicos e culturais.

(Morgenroth,1929 Apud Andrade, 1998, pág. 35)

Além destes conceitos, Fuster cita que foram elaboradas outras definições pela chamada "escola polonesa”, como a de Lesczyck que considera o movimento turístico aquele no qual participam os que durante um certo tempo residem num certo lugar, como estrangeiros ou forasteiros e sem caráter lucrativo, oficial (de serviços) ou militar.

(Fuster, 1974, pp. 24-28) 
Segundo De La Torre (1992), outros estudos, fora da escola berlinesa, deram origem a outras definições de turismo, algumas pobres conceitualmente, outras com uma maior visão da amplitude do Turismo. Entre estes conceitos pode-se citar os de:

A.J.Norwal (Inglaterra, 1936) acrescenta um elemento à definição - o turista - o qual gasta no destino o dinheiro ganho no seu país de origem. Turista é a pessoa que entra em um país estrangeiro sem a intenção de fixar residência nele, ou de nele trabalhar regularmente, e que gasta, naquele país de residência temporária, o dinheiro que ganhou em outro lugar.

Michele Troisi (Itália, 1942) afirma ser o turismo o conjunto das viagens temporárias de pessoas, motivadas por necessidades de repouso, de cura, espirituais ou intelectuais.

Donald Lundberg (Estados Unidos, 1974): “o turismo é a atividade de transporte, cuidado, alimentação e entretenimento do turista, tem um grande componente econômico, mas suas implicações sociais são bem mais profundas. Estimula o interesse no passado, na arquitetura e na arte...”.

(De La Torre, 1992, pág. 17)

Além dessas definições de Turismo, há várias outras. Para Arrillaga (1976, pág.25) o turismo “é o conjunto de deslocamentos temporais determinados por causas alheias ao lucro; conjunto de bens, serviços e organização que determinam e tornam possíveis estes deslocamentos e as relações e fatos que entre aqueles e os viajantes têm lugar”.

O fato mais relevante é que o turismo não pode ser visto apenas como uma “indústria de viagens de prazer”. Trata-se de algo maior, mais complexo. Não é um simples negócio ou comércio, pois o mesmo tem implicações consideráveis geradas na sociedade e, especificamente em seus integrantes, as pessoas.

Para Burkart e Medlik (1974, p. 39-40) o turismo "é uma amálgama de fenômenos e relações, fenômenos estes que surgem por causa do movimento de pessoas e sua permanência em vários destinos”. Neste conceito estão inseridos no turismo dois elementos diversos entre si: a viagem (elemento dinâmico) e a estada (elemento estático). 
A questão principal do Turismo é que as pessoas desenvolvem atividades diferentes do que costumam fazer em seu cotidiano, quando estão fora de suas residências fixas. O movimento constitui-se em algo particular, motivado por seu caráter temporário - o turista sempre pensa em voltar para casa em pouco tempo. A mudança é algo que fascina e amedronta o ser humano, que o atrai e ao mesmo tempo o repele.

Uma das mais recentes definições de turismo é a de Oscar de La Torre que afirma que o turismo é um fenômeno social que consiste no deslocamento voluntário e temporário de indivíduos ou grupos de pessoas que, fundamentalmente por motivos de recreação, descanso, cultura ou saúde, saem do seu local de residência habitual para outro, no qual não exercem nenhuma atividade lucrativa não remunerada, gerando múltiplas inter-relações de importância social, econômica e cultural.

(De La Torre, 1992, pág. 19)

Pode-se perceber a infinidade de definições do Turismo em várias épocas, criadas em diferentes locais do mundo e com a predominância de determinadas variáveis existentes nestes espaços e tempos diferenciados, de acordo com o contexto socioeconômico, cultural político e geográfico em que foram elaboradas.

Pelo fato de não ser o objeto principal de preocupação do presente trabalho a criação ou discussão de qual é o melhor conceito de turismo e, para reduzir as dificuldades provenientes destas inúmeras definições, adota-se, como forma de universalizar este conceito e para a continuidade do estudo do objeto proposto, a definição formal da Organização Mundial do Turismo (OMT) definida por De La Torre (1992, pág.19) como o turismo sendo: “a soma de relações e de serviços resultantes de um câmbio de residência temporário e voluntário motivado por razões alheias a negócios ou profissionais”. 


\section{REVISÃO BIBLIOGRÁFICA}

\section{A) DESENVOLVIMENTO SUSTENTÁVEL}

A moderna sociedade estabeleceu um modelo socioeconômico que prima pelo aumento da produção e da produtividade, deixando em segundo plano os demais elementos que compõem o conceito de desenvolvimento. Apesar dos avanços tecnológicos e produtivos, assiste-se, paralelamente, a uma exponencial concentração da renda e ao aumento das desigualdades sociais no mundo. Em paralelo às desigualdades sociais ocorre o aumento da degradação ambiental. Embora esta perspectiva não seja atualmente tão acentuada em países desenvolvidos - em função dos mecanismos de eqüidade social encontrados nestas nações - ela se revela de forma inexorável nos países em desenvolvimento.

O modo de produção vigente exige um ganho crescente de escala de produção (economia de escala), maiores níveis de produtividade e qualidade, redução de custos operacionais - administrativos e financeiros - resultando em um maior nível de concentração e centralização do capital $^{1}$; fatores que levam à concentração da renda e ao aumento do número de excluídos dos processos de produção e distribuição de produtos e serviços ${ }^{2}$.

A inclusão e a exclusão não se restringem, portanto, às fronteiras geopolíticas, mas ao âmbito dos relacionamentos social, político e econômico das estratificações sociais, independente da nacionalidade. As organizações públicas e privadas que mantêm intra e inter-relacionamentos para além dos seus respectivos limites territoriais, atuam de forma globalizada, formatam, com isso, uma estrutura social de incluídos e excluídos. Com isso,

\footnotetext{
${ }^{1}$ Refere não apenas ao capital monetário, mas ao capital financeiro, fixo e social.

${ }^{2}$ Em que pese a exigência da modernização das relações sociais de produção, as relações democráticas de organização social permeiam toda e quaisquer estruturas sócio-produtivas. É latente o clamor social no que diz respeito ao reconhecimento dos direitos sociais, pois, não é concebível e sustentável uma sociedade em que os níveis de indigência e exclusão social gravam uma parcela cada vez maior da sociedade. O reconhecimento do direito à propriedade privada tem como condição sine qua non o reconhecimento dos direitos sociais.
} 
inclusão e exclusão tornam-se os termos de referência para a mensuração dos níveis de desigualdades encontradas em um Estado organizado, afinal um cidadão da elite socioeconômica brasileira interage muito mais com o seu par estrangeiro do que com seu compatriota socialmente excluído.

O volume e a intensidade destes relacionamentos extrapolam a dimensão de seus interesses precípuos, desdobrando-se em secundários e, apoderam-se da ética e da lógica da sociedade, determinando quem serão ou não seus interlocutores, prepostos e beneficiários, isto de forma institucionalizada, legal e revestida de um caráter de naturalidade.

Outro aspecto de extrema relevância é a falta de perspectiva para a permanência do cidadão em seu local de origem, tornando inevitável o êxodo rural, o qual gera efeitos desastrosos para toda uma sociedade. Os problemas gerados pela falta de perspectiva no campo/interior resultam em um processo acelerado de migração, o qual cria a necessidade de adaptações constantes do planejamento municipal de desenvolvimento, visto as inúmeras alterações provocadas pelo aumento ou recuo populacional e, consequentemente, a ocorrência de variações nas demandas públicas. Cria-se com isso, cenários repletos de elementos de incerteza, tornando mais complexo o processo de tomada de decisões pelas autoridades governamentais constituídas na elaboração de políticas públicas.

Ao se oportunizarem relações de trabalho e emprego, consubstanciadas pela constituição de um padrão sócio-produtivo dinâmico, pautado na cooperação e cidadania, capaz de garantir níveis satisfatórios de qualidade de vida, o trabalhador não mais se deslocará em direção aos grandes centros em busca de trabalho. O emprego é necessário para que as pessoas continuem a viver em suas localidades.

O turismo, em seu sentido social, é uma das atividades que mais geram o pretendido aumento dos níveis de emprego de uma localidade. Uma forma de mudar este contexto está na implantação de uma nova forma de desenvolvimento socioeconômico que seja capaz de reduzir os efeitos do modelo de desenvolvimento utilizado atualmente. Cria-se, assim, o conceito de desenvolvimento sustentável, o qual prioriza a melhoria da evolução da vida em sociedade de forma continuada e equilibrada, sem a degradação o meio ambiente.

Segundo Ehlers (1999, p.102-103), “a palavra sustentável tem origem no latim sustenere, traduzida para o inglês em 1290, referindo-se ao uso responsável da terra, dos 
recursos bióticos, florestais e dos recursos pesqueiros”. Na sua raiz o termo “sustentável” está intrinsecamente ligado ao respeito e a preservação do meio ambiente, como defende a abordagem ambientalista.

O termo desenvolvimento sustentável exige a incorporação de princípios e valores éticos. Segundo Irving (2002, pág. 17), o termo é "uma nova forma de pensar a democratização de oportunidades e benefícios e, um novo modelo de implementação de projetos, centrado em parceria, co-responsabilidade e participação”. Há pressupostos éticos e de solidariedade que também caracterizam a questão do desenvolvimento sustentável. O principal desafio da humanidade neste século é encontrar opções de desenvolvimento dentro de um conceito de sustentabilidade e perenidade.

A definição de sustentabilidade depende da referência de quem o está fazendo. Para um pequeno agricultor, sustentabilidade pode significar a posse de uma propriedade autônoma e independente, principalmente no quesito financeiro. Na visão capitalista, um projeto é sustentável quando gera retorno financeiro ou lucro. Na visão social este deve atender aos anseios e demandas da sociedade. Na visão ecológica tem de preservar e respeitar o meio ambiente.

No documento “Nosso Futuro Comum” elaborado pela Comissão Mundial sobre Meio Ambiente e Desenvolvimento da Organização das Nações Unidas CNMAD/ONU (1987, pág. 43), definiu-se desenvolvimento sustentável como “o desenvolvimento que faz face às necessidades da geração presente sem comprometer a capacidade das gerações futuras de satisfazer as suas próprias necessidades”.

Para Matos; Tsuji, e Miranda (2002, pág. 7) as turbulências sociais brasileiras vividas no início de século XXI, “são resultantes de um “padrão de desenvolvimento socialmente perverso, concentrador de renda, de riqueza, de oportunidade, de conhecimento, de ativos produtivos e de poder” levando à desintegração comunitária, à fragmentação social. Conduzem à uma redução dos níveis de qualidade de vida e, por conseqüência, à própria degradação ambiental, isto, fruto da insustentabilidade do modelo de desenvolvimento mundial atual .

A falta de capacidade de suporte do meio ambiente diante das atividades econômicas devastadoras é percebida pelo tempo gasto pela natureza para se recompor depois de um processo de exploração econômica desenfreada. 
O modelo de crescimento que ameaça a conservação e reprodução dos recursos naturais apresenta uma insustentabilidade política e social, devido à profunda desigualdade na distribuição da riqueza e da qualidade de vida.

Conforme Matos; Tsuji, e Miranda, nos últimos 30 anos, o PIB do mundo cresceu cerca de $100 \%$. Já o percentual da pobreza cresceu 1.000\%. Aproximadamente 25 milhões de pessoas tornam-se pobres por ano. Pela primeira vez, desde 1990, o índice de desenvolvimento humano caiu em 30 países. Cerca de 1,3 milhões de pessoas vivem com renda inferior a um dólar por dia. A diferença de renda per capita entre o país mais rico e o mais pobre do mundo é de 140 para 1 . No mundo, trezentas e cinqüenta e oito famílias são tão ricas quanto 2,5 bilhões de pessoas, quase a metade da população da terra. Em cada três brasileiros um é pobre.

(Matos; Tsuji, e Miranda, 2002, pág. 10)

A aceleração e a amplitude dos impactos ambientais e dos problemas sociais em diversas regiões e países tornam o meio ambiente e a pobreza uma questão de abrangência planetária e um problema global altamente explosivo. Este processo de degradação possui uma escala mundial.

Para Buarque essa globalização dos problemas força “certa solidariedade” entre os povos. Na medida em que a agressão ao meio ambiente em cada local contribui para a deterioração geral da natureza e, que a explosão da pobreza e da desigualdade atravessa as fronteiras e ameaça a estabilidade das regiões e dos países ricos este fenômeno torna-se mais forte.

(Buarque, 1999, pág. 30)

Esta realidade, amplamente divulgada pela globalização dos meios de comunicação, causou uma reviravolta na definição de desenvolvimento sustentável. A partir da década de 90, o conceito proposto pela Comissão Mundial Sobre Meio Ambiente e Desenvolvimento da Organização das Nações Unidas - ONU (CMMDA) amadureceu e ganhou uma nova dimensão, que inclui a perspectiva de pressupostos éticos e de solidariedade humana, partindo para o respeito e o comprometimento intra-gerações, não somente entre gerações. 
O desenvolvimento sustentável parte de uma nova perspectiva de desenvolvimento e, se estrutura sobre duas solidariedades: a solidariedade "sincrônica”, com a geração à qual se pertence, e a solidariedade "diacrônica” com as gerações futuras”.

(Sousa, 1994 apud Buarque, 1999, pág. 31)

Em conformidade com essa proposição, pode-se citar a idéia de que o bem estar das gerações atuais não podem comprometer as oportunidades e necessidades futuras, e o bem-estar de uma parcela da geração atual não pode ser construída em detrimento de outra parte, com oportunidades desiguais na sociedade. As duas formas de solidariedade estão estreitamente interligadas.

(Sachs, 1990 apud Buarque, 1999 pág. 31)

O agravamento do cenário social no Brasil, resultado do aumento do desemprego, da degradação ambiental, da ocupação desordenada dos territórios; reflete um quadro de disparidades que tende a se acentuar, pois é fruto de um processo de exclusão que se modifica no tempo, no espaço e conceitualmente ${ }^{3}$.

No Estado de Goiás, caracterizado como um membro federativo essencialmente agropecuário, esta realidade não é diferente. Sua extensão territorial estabelece acentuadas disparidades inter e intra-regionais em virtude dos diferentes níveis de desenvolvimento, onde regiões produtoras de commodities contrastam com regiões cuja subsistência é obtida através da agricultura familiar. A atividade agropecuária é reconhecida como geradora de fortes impactos ambientais, neste fato está a necessidade de se implantar atividades econômicas complementares e alternativas nas regiões ainda preservadas, criando áreas ou zonas tampões, que impeçam ou reduzam uma expansão agropecuária ainda mais acelerada em áreas de ecossistemas considerados frágeis, como o cerrado. Na região nordeste do Estado de Goiás prevalece um quadro social com grande desigualdade na distribuição de

\footnotetext{
${ }^{3}$ O processo de exclusão social possui características diferenciadas tanto no aspecto temporal (quando) quanto espacial (onde), dependendo do nível de organização social em que ocorre. Há modificação conceitual da exclusão social; o termo exclusão digital é expressão de uma nova abordagem em que diferentes nuances são consideradas. A necessidade em cunhar novos termos reflete a mudança conceitual de exclusão social.
} 
renda, mortalidade infantil elevada, condições sanitárias e habitacionais precárias, terras ocupadas sem posse de títulos de propriedade e baixa oferta de energia elétrica; fatores que contribuem e retroalimentam um círculo vicioso no qual se estabelece uma máxima: é a pobreza de um local resultado de sua situação de pouco desenvolvimento, ou é o seu pouco desenvolvimento resultado da pobreza local. É a exclusão social se materializando por toda uma região, exigindo cuidados especiais e tratamento prioritário adequado para modificar um panorama que, caso perdure, comprometerá irreversivelmente todo e qualquer processo de desenvolvimento sustentável que venha a ser planejado. Este fato está na perda de credibilidade das pessoas diante de inúmeros programas de desenvolvimento que não deram certo. São esperanças que se perdem e que ficarão, de forma inconsciente ou consciente, impregnadas na cultura local.

Buscando minimizar a precária situação em que se encontra a população da região nordeste de Goiás e reduzir os desequilíbrios regionais com investimentos em programas sociais e de diversificação econômica, o Governo do Estado está implementando ações e programas de Desenvolvimento sustentável direcionadas a esta localidade. Não obstante aos esforços empreendidos, persistem os desequilíbrios. O fraco capital social, a falta de capacitação e a baixa qualificação profissional no Nordeste Goiano, tem como causas os desequilíbrios socioeconômicos, políticos, culturais e institucionais, fatores que decorrem do mercado de trabalho insuficiente, da falta de iniciativa da população em atuar com eficiência na defesa de seus direitos e da incapacidade de se organizarem. Essa situação revela que as medidas paliativas convencionais perderam a sua eficácia pela falta de credibilidade da população perante os mesmos. O modelo chegou a tal grau de esgotamento que já não é mais possível recuperá-lo; simplesmente se faz necessário substituí-lo por uma estratégia educativa emancipadora.

Conforme Lacki, com tal fim os governos, conscientes de que não estão em condições de fazer tudo por todos sempre, terão de assumir o papel de, essencialmente, emancipador de dependências. Com este propósito deverão delegar às próprias populações locais a solução de seus principais problemas, proporcionandolhes conhecimentos mínimos para que verdadeiramente queiram, saibam e possam assumir, atitudes e papéis mais protagônicos na eficiente solução dos seus próprios problemas.

(Lacki, 1999, pp. 1-2) 
Entre estas decisões está a assimilação pelas comunidades da consciência da necessidade de um planejamento de atividades que proporcionem o desenvolvimento regional sustentável. Um plano de ecoturismo é uma das alternativas a serem implementadas para que se atinja parte deste propósito.

A questão maior é: qual a real possibilidade de fortalecimento ou de crescimento dessa comunidade? Como conseguirão vencer estes desafios sem uma estratégia de apoio? A sociedade precisa se posicionar diante das opções de desenvolvimento, devendo ser esclarecida sobre as diferentes possibilidades existentes, de forma a poder exigir políticas públicas coerentes com as opções escolhidas mais condizentes com sua realidade.

A reorganização da sociedade é a base para o início de alguma perspectiva de desenvolvimento sustentável, a qual deve ser obtida de modo que as comunidades tenham capacidade de criar condições éticas, econômicas, institucionais e técnicas para que um processo de mobilização social ocorra, possibilitando a sistematização do desenvolvimento local. Sendo assim, serão valorizados os elementos estratégicos intangíveis, como o capital humano e social, o “empoderamento” das pessoas e das organizações.

A transição para uma sociedade sustentável é complexa. Segundo Jara (1999, pág. 40) esta transição "é um problema de tomada de consciência que começa na mudança interna das pessoas, nos sentimentos de solidariedade, no amor político pela sociedade, um novo pacto do ser humano com todos os demais seres, com a natureza”.

A construção do futuro de uma região depende da comunidade como sujeito capaz de propor um desenvolvimento sustentável, isso só acontecerá se a comunidade romper com os relacionamentos de dependência, pois não há a possibilidade de um futuro sustentável se não houver transformações pessoais promovidas pela educação e pela participação social.

Segundo Matos e Miranda a idéia da sustentabilidade está diretamente relacionada à continuidade, à permanência da qualidade de vida e às oportunidades da sociedade ao longo do tempo, incorporando uma perspectiva de longo prazo. Parte de uma base ética que demanda uma solidariedade social. Pressupõe a necessidade de subordinação da dinâmica econômica aos interesses da sociedade e às condições do meio ambiente, traduzindo-se, portanto na solidariedade inter e intra-gerações e também numa solidariedade inter-regional.

(Matos e Miranda, 2002 pág. 13) 
O fortalecimento das capacidades de autogestão, decisão e participação são o fundamento do desenvolvimento sustentável. É principalmente uma questão de planejamento, de visão de futuro e de mudança de consciência da população local.

Assim, a definição de desenvolvimento sustentável mais atual, madura e completa é a que compreende o desenvolvimento sustentável como sendo aquele que faz face às necessidades das gerações presentes sem comprometer a capacidade das gerações futuras de satisfazer as suas próprias necessidades, respeitando o pressuposto que o bem estar de uma parcela da geração atual não pode ser construída em detrimento do bem estar de outra parcela desta mesma geração.

De acordo com Matos e Miranda o desenvolvimento sustentável é entendido como um processo amplo e abrangente de mudança social e aumento das alternativas de escolhas e oportunidades da sociedade, de modo a compatibilizar, no tempo, o crescimento econômico, a eqüidade social e a preservação do meio ambiente”.

(Matos e Miranda, 2002 pág. 13)

Nesse contexto insere-se a necessidade de mobilização social para cooperação, que tem como objetivo básico, a participação ativa dos atores envolvidos no processo e que busque a eqüidade, em que a única alternativa realista consiste em proporcionar à comunidade os conhecimentos para que eles mesmos possam solucionar os seus problemas, com capacitação e tecnologias compatíveis com os recursos que realmente possuem.

São João d'Aliança é um dos municípios integrantes da realidade do nordeste goiano. Localidade de ricos cenários e de belas paisagens que dispõe de um grau de preservação ambiental mais acentuado que as demais localidades do estado de Goiás, mas que ainda possui problemas de desemprego, economia debilitada, educação precária e saneamento básico insuficiente aos quais se adiciona uma expansão acelerada da área cultivada pela agricultura - atividade devastadora por sua própria natureza - fatores que atuam de forma conjunta para que cada vez mais a degradação ambiental do cerrado aumente neste município. 


\section{A.1) Características do Desenvolvimento Local Integrado Sustentável}

Na prática, a aplicação do conceito de desenvolvimento local, integrado e sustentável desdobra-se nas dimensões ambiental, econômica, tecnológica, social, cultural e políticoinstitucional, as quais devem ser operacionalizadas de forma holística, sistêmica e integrada. Para que isto ocorra, é necessário que o enfoque dado à intervenção proposta tenha uma perspectiva de totalidade, ou melhor, não seja segmentada ou setorializada.

A necessidade do conceito de território, definido por sua identidade natural e cultural, passa a ser a unidade de planejamento e de execução das ações de desenvolvimento local sustentável, tornando mais nítida a área de implementação da metodologia de desenvolvimento. Portanto, onde se ler "local”, pode-se entender o conceito “territorial”, termo recentemente mais utilizado pelos órgãos governamentais, pela maior amplitude deste conceito. Para um melhor entendimento destas dimensões, cabe destacar alguns aspectos relevantes, como o aspecto ambiental, o econômico, o tecnológico, o social, o político institucional e o cultural.

Para Matos e Miranda, define-se o aspecto ambiental quando se consegue considerar os ecossistemas particulares; a disponibilidade dos recursos naturais renováveis e não-renováveis; a disponibilidade, a tendência de esgotamento, o uso atual e a qualidade dos recursos hídricos; a disponibilidade e a tendência de esgotamento dos recursos florestais e da fauna, além de aspectos relacionados ao solo, ao relevo e ao clima. Ou seja, no âmbito da dimensão ambiental busca-se analisar, sob diferentes ópticas, a influência presente e futura do homem com a qualidade geral do meio ambiente natural e a preservação da biodiversidade, o que inclui, por exemplo, uma avaliação da poluição hídrica e atmosférica do nível de (des)organização dos ecossistemas existentes.

(Matos e Miranda, 2002, pp. 14-15)

O aspecto econômico, inclui a dinâmica geral da economia, considerando, dentre outros aspectos: as relações econômicas e comerciais com o contexto do território, as estruturas produtivas, o peso relativo dos setores produtivos, as cadeias produtivas e os complexos econômicos relevantes, as condições e a oferta de infra-estrutura (transporte, 
energia e comunicação), a logística econômica, as vantagens competitivas e as potencialidades ou oportunidades oferecidas pelo mercado. Envolve, ainda, a análise de indicadores econômicos relacionados à renda, taxa de investimento, taxas de crescimento e, por fim, os sistemas institucionais de fomento, regulação e crédito existentes.

O aspecto tecnológico diz respeito a uma visão do padrão tecnológico dominante no território e ao nível de produtividade. Descreve qualitativamente os pontos de estrangulamento, as carências e as demandas que afetam a produtividade e comprometem a qualidade dos produtos, visando um aumento de produção associada à sustentabilidade ambiental (adequabilidade com os ecossistemas). Supõe, ainda, o conhecimento dos sistemas de pesquisa, extensão rural, inovação e capacitação científica e tecnológica (universidades, instituições de Pesquisa e Desenvolvimento, organismos de fomento produtivo, etc.) e a qualificação de recursos humanos existentes.

Os entes sociais, considerando a evolução geral da população, sua estrutura e suas tendências, relações sociais, emprego e estrutura de renda, cidadania, oferta e qualidade da infra-estrutura social (saúde, saneamento, habitação), situação geral da educação e da formação de recursos humanos (analfabetismo, nível de escolaridade, oferta de ensino, etc.), relações de trabalho, estrutura fundiária e indicadores sociais (sempre que possível comparando com parâmetros gerais que podem constituir modelo).

O elemento cultural - incluiu uma análise antropológica dos grupos sociais dos territórios e suas diferentes manifestações histórico-culturais, artísticas e artesanais, em específico. Busca entender a identidade cultural comum e a sua tradução nas diferentes formas de manifestação (culinária, forma de produzir e comercializar), os valores religiosos, éticos e morais, as regras consuetudinárias, as diversas formas de relacionamento interno e externo ao território, as redes de solidariedade e cooperação existentes, dentre outros aspectos. Em outras palavras, a dimensão cultural considera os padrões e as regularidades de comportamento que revelam o jeito de ser de um grupo humano, em meio à dispersão de atitudes, capaz de representar as energias coletivas as quais, muitas vezes, contrapõem-se à “racionalidade” dos elementos econômicos.

O caráter político-institucional, relacionado ao exercício do poder local e às relações externas com distintas instâncias de poder, inclui a análise do sistema político e a estrutura de poder prevalecente, atores sociais e seus interesses, organização do estado e da sociedade, governabilidade, situação geral do setor público, relações entre o Estado e a 
sociedade, quadro geral das instituições públicas e privadas, nível de organização e participação da sociedade, destacando-se as principais instituições presentes no território.

Estes elementos se integram, como ocorre com o capital social que permeia várias dimensões. As dimensões referidas devem estar sempre presentes em quaisquer iniciativas de desenvolvimento local sustentável, entretanto, as especificidades dos distintos territórios definem a importância relativa de cada uma delas.

O desenvolvimento local sustentável é, portanto, um processo e uma meta a ser alcançada em médio e longo prazo, gerando uma reordenação do estilo de desenvolvimento, adequando-se de acordo com as características específicas de cada território. Consiste numa transição para um novo estilo de organização da economia e da sociedade e das suas relações com a natureza, prenunciando uma sociedade com equidade social e conservação ambiental. Esta compatibilização entre objetivos sociais, econômicos e culturais torna-se uma possibilidade concreta com os avanços científicos e tecnológicos mediadores fundamentais das relações da economia e da sociedade com a natureza - e com o crescimento da consciência ambiental da humanidade.

A consciência ambiental confere sustentação política às mudanças e, as inovações tecnológicas redefinem e podem moderar as tensões (conflitos estruturais) entre a economia e a natureza. A integração participativa do cidadão na vida política e social é também um fator importante para a sustentação das políticas, assegurando a efetividade e a continuidade das decisões.

Há a necessidade de também enfatizar a introdução da inversão da lógica do desenvolvimento, onde ocorre a transferência dos centros das decisões de qualquer instância (Estado, Organizações Não Governamentais ou outras instituições), principalmente da área governamental, para o ambiente comunitário local. Isto fortalece o capital social e gera empoderamento desse capital e da comunidade e, por conseqüência, resulta na sua independência.

O desenvolvimento local é resultado de múltiplas ações convergentes e complementares, capazes de quebrar a dependência e a inércia do subdesenvolvimento e do atraso em localidades periféricas e de promover uma mudança social no território. Deve-se perseguir com rigor o aumento da renda e da riqueza locais, por meio de 
atividades econômicas viáveis e competitivas, com capacidade de concorrer em mercados locais, regionais e, no limite, globais.

As experiências bem-sucedidas de desenvolvimento local (processo endógeno) decorrem, quase sempre, de um ambiente político e social favorável expresso por uma mobilização e, principalmente, pela convergência importante de atores sociais do município ou comunidade em torno de determinadas prioridades e orientações básicas de desenvolvimento. O desenvolvimento local está associado, normalmente, a iniciativas inovadoras e mobilizadoras da coletividade, articulando as potencialidades locais nas condições dadas pelo contexto externo.

As comunidades procuram, então, utilizar suas características específicas e suas qualidades superiores para se especializarem nos campos em que têm uma vantagem comparativa em relação às outras regiões. Portanto, ao se analisar estes fatores, pode-se afirmar que o desenvolvimento sustentável é endógeno, humano e local, onde a sociedade organizada rompe com o determinismo de estar em um tipo de desvantagem em relação a outras comunidades. Assim, as comunidades conscientes assumem para si o papel de sujeito e de responsável pelo seu próprio destino e explora suas potencialidades culturais e naturais transformando-as em prosperidade social e econômica coletiva, sempre em harmonia com o meio ambiente.

Na percepção do Brasil, o desenvolvimento sustentável é um conceito integrado que promete crescimento contínuo, a melhoria das condições humanas e a manutenção do patrimônio natural para as futuras gerações. Os fatores dessa equação não podem ser dissociados ou analisados isoladamente. Essa equação promove o modelo ideal de uma nova civilização para o próximo século e deveria ser o processo e a substância do que se denomina de globalização, ou seja, da modernização do planeta como um todo. 


\section{B) ECOTURISMO}

\section{B.1) Conceitos}

O uso do termo “Ecoturismo” está na moda. Porém, ele está sendo utilizado de forma inconveniente, inoportuna e indevida pelas instâncias governamentais e pelos agentes vinculados ao ramo do segmento turismo. A observação do oferecimento de pacotes ecoturísticos por agências de turismo que não possuem o mínimo comprometimento com a natureza e a cultura da localidade receptora constitui-se em uma realidade negativa no Brasil.

Em 1984, a Assembléia Geral da Organização das Nações Unidas (ONU), na sua 38 sessão, criou a Comissão Mundial sobre Meio Ambiente e Desenvolvimento. Surgiram, assim, as diretrizes para o Desenvolvimento Sustentável - uma política mundial empenhada em garantir as necessidades humanas dos tempos atuais, sem comprometer a capacidade das gerações futuras de atenderem às suas. Desta comissão saíram as bases para a formatação das Diretrizes para uma Política Nacional de Ecoturismo. Os entes do ramo turístico não têm atendido às exigências estabelecidas neste documento elaborado pela EMBRATUR em parceria com o IBAMA, em 1994.

Para Irving, o ecoturismo é entendido como modalidade de turismo sustentável e, não apenas como um segmento da atividade turística, centrado exclusivamente no bem natural. Esse entendimento é compartilhado pela União Internacional para a Conservação da Natureza (IUCN) que adota o conceito proposto por CeballosLauscuráin (1993), no qual o ecoturismo é entendido como uma viagem ambientalmente responsável e, como visitação de áreas naturais relativamente preservadas, no sentido de vivências e apreciar a natureza, que promove a conservação, tem baixo impacto e promove, de forma benéfica, o envolvimento socioeconômico ativo das populações locais”.

(Irving, 2002 pág. 30)

Embora se tenha disponibilizado um aparato conceitual responsável e dependente da natureza, o que se tem visto na prática é o equívoco de se entender o ecoturismo como 
mera modalidade do turismo na qual o bem natural é o único atrativo e, os compromissos globais são inexistentes.

Segundo Irving (2002, pág. 19), a terminologia ecoturismo é definida pelas Diretrizes para uma Política Nacional de Ecoturismo como um segmento da atividade turística que "utiliza, de forma sustentável o patrimônio natural e cultural, incentiva a conservação ambiental e busca a formação de uma consciência ambientalista por meio da interpretação do ambiente, promovendo o bem-estar das populações envolvidas”.

Este tópico das divergências conceituais e da realidade vigente, equacionado e trabalhado metodologicamente, pode vir a surtir efeitos para a efetivação de programas de educação ambiental. Estes programas devem, portanto, enquadrar o ecoturismo como uma modalidade de turismo sustentável. A utilização desta terminologia deverá contribuir para a efetividade do desenvolvimento sustentável.

O entendimento e assimilação do termo ecoturismo requer uma nova fase de crescimento econômico mundial e, uma atenção diferenciada para as nações em desenvolvimento - onde as populações mais carentes passem a participar de uma parcela mais justa da nova economia gerada.

Para atingir esses objetivos, faz-se necessário que as comunidades locais que tenham o intuito de atuar em atividades ecoturísticas, participem ativamente dos processos de decisão, através de uma participação comunitária efetiva dentro dos seus sistemas políticos.

Dentro desta perspectiva, abriu-se espaço para a implantação e consolidação do ecoturismo, aliado à educação ambiental, como sendo uma das formas de alicerce do desenvolvimento sustentável, promovendo a conscientização das populações que se envolvem neste fluxo migratório, como o pólo emissor e receptor, seja em âmbito nacional ou internacional.

Populações devidamente capacitadas e esclarecidas podem contribuir na preservação de patrimônios naturais cênicos, culturais, étnicos, da flora e da fauna e obter, em troca, os benefícios gerados pela atividade econômica do turismo. 
Segundo a Organização Mundial do Turismo (OMT, 2001), o turismo mundial movimenta mais de 3,5 trilhões de dólares por ano; em impostos gera 655 bilhões, oferece $10,6 \%$ do trabalho global. No Brasil, representa 7,8\% do Produto Interno Bruto (PIB) com 8,8\% dos empregos. O ecoturismo aparece como uma das vertentes do turismo mais promissoras neste cenário.

As populações urbanas desejam cada vez mais o contato com a natureza para poderem desfrutar do sentimento de liberdade e sentir a presença do meio ambiente, cada vez menos presente nos grandes centros urbanos. Além de poderem sair de um ambiente repleto de poluição atmosférica e psicológica -proveniente da sensação de abuso ocorrida no sistema desigual de troca do fator econômico do trabalho pelo fator renda.

Ecoturismo, turismo de baixo impacto, turismo alternativo, de esportes radicais (escalada, rafting, rapel, cannyoning, mountainbike, entre outras modalidades), turismo de observação de pássaros e animais, agroturismo e tantas outras denominações, têm em comum a finalidade que as localidades visitadas (pólo receptor) buscam, o alcance do desenvolvimento sustentável, contribuindo para que esse pólo esteja apto a lidar com um fluxo de pessoas que desejam um maior contato com a natureza e para que possam aprender um pouco sobre as características das localidades visitadas.

O pólo emissor deve contribuir com esse desenvolvimento, enviando pessoas preparadas para lidarem com as diferenças culturais e étnicas encontradas, respeitando as mesmas e os recursos naturais, procurando diminuir os impactos causados em todos esses elementos.

A política de ecoturismo no Brasil, segue a definição sugerida pelas Diretrizes para uma Política Nacional de Ecoturismo, considerando este um segmento da atividade turística, que deve utilizar, de forma sustentável, o patrimônio natural e cultural, incentivar sua conservação e buscar a formação de uma consciência ambientalista através da interpretação do ambiente, promovendo, com isso, o bem-estar das populações envolvidas.

Através de sua prática, as localidades com potencial e vocação natural para esse tipo de empreendimento apresentam um número considerável de atrativos ecoturísticos, dada a diversidade geográfica e cultural do país. Os mais variados ecossistemas são encontrados de norte a sul, de leste a oeste. A Floresta Amazônica, a Mata Atlântica, os 
campos de altitude, os cerrados, o Pantanal, as zonas costeiras, os mangues, as ilhas, as diversas áreas de preservação, Parques Nacionais e Estaduais.

Todas essas localidades podem ser beneficiadas sob o ponto de vista socioeconômico, pois as populações residentes terão condições de se desenvolverem e permanecerem nas suas regiões de origem, diminuindo o êxodo rural, preservando os recursos, gerando empregos locais e trazendo o desenvolvimento de forma sustentável para as regiões que se empenharem nesta modalidade do turismo. O ecoturismo também participa indiretamente da melhoria da infra-estrutura de transporte, comunicação e saneamento, resultando em benefícios para a população residente na localidade receptora.

O ecoturismo deve estar associado à educação ambiental para que as partes envolvidas na rede turística reconheçam o porquê da necessidade do respeito devido às particularidades das localidades e da cultura das populações visitadas. Os turistas devem ter um sentimento de responsabilidade para com a localidade receptora, não pensando que os atrativos das localidades receptoras estão disponíveis apenas para seu usufruto em troca de meros recursos financeiros.

Todas as atividades realizadas na natureza geram impactos. Em face desta problemática, é de vital importância que todos os envolvidos na rede turística estejam conscientes e capacitados para gerenciarem estas atividades de modo a manter uma relação de respeito com o meio ambiente, para que este não se descaracterize ou seja impactado de forma a não se possibilitar a continuidade da prática das atividades ecoturísticas em determinado local. Quando bem gerenciados, os impactos podem ser mínimos em relação aos benefícios advindos da prática do ecoturismo.

No Brasil, esta atividade cresce a cada dia. Novas agências especializadas são criadas. A indústria nacional de equipamentos para a prática de muitas das modalidades deste tipo de turismo tem gerado um novo segmento de mercado a ser explorado, introduzindo novos materiais e dando maior segurança aos praticantes destas atividades, diminuindo, assim, os riscos de acidentes.

Cursos de capacitação são ministrados, assim como cursos de formação de pessoal especializado são criados nos centros urbanos, para que cada vez mais os dois pólos receptor e emissor - estejam aptos a lidarem com esse mercado relativamente novo. Novos empreendimentos estão sendo implantados, contribuindo para uma maior e melhor 
distribuição de renda, através da criação de novos empregos, da arrecadação de impostos e da aplicação destes recursos na área social.

É de suma importância que as diversas esferas de governo, os vários elementos que compõem o "trade ecoturístico" e a população - de forma geral - saibam de suas responsabilidades para que o ecoturismo possa ser, definitivamente, uma atividade geradora de renda e de benefícios ambientais para o Brasil.

A qualidade em ecoturismo significa respeito à natureza, informação correta para o visitante e guias preparados. Como o ecoturismo virou moda, inclusive no Brasil, surgiram muitas pessoas ou empresas se propondo a organizar produtos turísticos especializados na área.

No entanto, há muitas empresas entrando no mercado e que ainda não dispõem de credibilidade. Os órgãos vinculados ao turismo sugerem que os turistas procurem as agências de turismo especializadas em natureza que são aquelas que estão associadas ao IEB- Instituto de Ecoturismo do Brasil - a organização brasileira reconhecedora das empresas de ecoturismo profissionalizadas.

\section{B.2) Sustentabilidade do Ecoturismo}

A sustentabilidade do ecoturismo consiste na busca pela manutenção do recurso natural e cultural para as gerações futuras e pelo bem-estar das populações envolvidas. Além disso, se estabelece um compromisso ético fundamental, porque se pressupõe uma filosofia de vida diferenciada, norteada pelo compromisso de justiça social, democratização de oportunidades e percepção de longo prazo numa visão coletiva e solidária.

O setor empresarial do ramo turístico vem enfrentando modificações constantes na conjuntura onde se insere e faz da adaptação de suas organizações frente a esses desafios, o fator primordial de sua própria sobrevivência.

Uma postura pró-ativa com relação às questões ambientais, é parte constituinte dos novos paradigmas da qualidade total, da competitividade, da imagem e da responsabilidade social. Desta forma, o desempenho sustentável, que cada vez mais atrai a atenção de todos, 
pode influenciar significativamente a forma pela qual uma empresa é vista pelos clientes, comunidade e autoridades do governo. Nesse sentido, apresenta-se o paradigma do desenvolvimento sustentável, suas ações implementadoras e as medidas gerenciais e operacionais para a utilização de tecnologias limpas setor econômico.

Portanto, o fator sustentabilidade é mais um fator político que um fator ambiental, pois na definição das políticas públicas está o resultado da harmonia ou desarmonia social que têm efeitos poderosos sobre o meio ambiente.

\section{B.3) Ambientalismo X Ecoturismo}

A evolução do movimento ambientalista resultou na forma atual de Ecoturismo. Este processo representa os conflitos gerados entre a questão do desenvolvimento da produção capitalista e a preocupação dos ambientalistas em preservar o ambiente natural.

O Ecoturismo materializa a etapa de evolução da sociedade que consegue - de certa forma - alcançar uma definição daquilo que seria o desenvolvimento sustentável baseado no uso da natureza pelo homem, visando o seu auto-sustento com respeito e dignidade.

Segundo Christoffoli; Santos; Silva, e Dias (2002, p. 1-2), a evolução do Ambientalismo para o Ecoturismo passou por algumas etapas até tomar a forma atual, concretizada nas regras de conduta do ecoturista, procura deixar de ser apenas e tão somente objeto de estudo de alguns setores, para transformar-se, transfigurar-se nas ações diárias dos homens por todo o mundo. O que só foi possível após o momento em que ambas as correntes fundiram-se - as idéias ambientalistas de proteção ao ambiente natural transformam-se em possibilidades concretas de preservação através das regras de conduta dos ecoturistas - pois neste momento ocorre de fato uma interpolação entre teoria e ação prática na proteção do ambiente natural.

(Christoffoli; Santos; Silva, e Dias, 2002, pág. 1)

Percebe-se com isso, a sinergia existente entre ambos, pois os movimentos levam a adoção dos conceitos de turismo sustentável e de preservação ambiental, aspectos comuns às duas correntes. As afinidades que demonstram esta sinergia são a 
contemporaneidade, a mútua influência e a simbiose no sentido ecológico do tema. Esta simbiose entre o ambientalismo e o ecoturismo faz surgir movimentos dos cidadãos em países desenvolvidos ou periféricos em prol da preservação dos recursos naturais. A sinergia entre Ambientalismo e Ecoturismo faz surgir diversos movimentos dos cidadãos distribuídos em diferentes países, os quais lutam em prol da preservação dos recursos naturais.

A mútua influência é uma das principais afinidades que demonstram a sinergia entre o ambientalismo e o ecoturismo. Ocorreu em função da exploração, principalmente pelo poder público, de reservas com fins econômicos, estimulando o ecoturismo que, ao ser praticado de forma sustentada, levou a uma consciência cada vez maior do cidadão para a defesa dos recursos ambientais.

Conforme Serrano, um marco relevante para essa mútua influência foi a criação, em 1872, nos Estados Unidos, de uma área dedicada ao lazer popular: o parque de Yellowstone, o qual deveria prestar-se também para a preservação do prejuízo ou da espoliação de toda madeira, dos depósitos minerais, das curiosidades naturais, ou das maravilhas, dentro do dito parque, que deveriam ser mantidos em sua condição natural.

(Serrano, 1997, pp. 104-105)

A partir de então, inúmeros parques nacionais nos Estados Unidos fizeram crescer essa mútua influência entre o ambientalismo e o ecoturismo, que se espalhou pelo mundo sob a forma de reservas de proteção ambiental.

O desenvolvimento, a conservação, o desenvolvimento sustentável e as dimensões da sustentabilidade, até então parâmetros de desenvolvimento restritos ao Ecoturismo, passam a ser incorporados como os principais paradigmas do ambientalismo. Partindo deste novo olhar ambientalista o movimento passou a abarcar acontecimentos naturais, sociais, culturais, políticos e econômicos entendendo o ser humano como co-responsável por tudo que acontece no campo da sobrevivência física do planeta e na qualidade de vida de seus habitantes. 
Este maior envolvimento do indivíduo nas questões ambientais refletiu-se, dentre outros setores, no turismo, quando se iniciou uma maior procura por lugares onde houvesse uma nova determinação de relação homem/natureza. Através desta busca do homem pela natureza como sua fonte de inspiração, a partir da conscientização para a defesa do meio ambiente, a proteção dos ecossistemas naturais e dos processos ecológicos do planeta, surgiu uma forma de turismo alternativo ao de massa o qual denominou-se Ecoturismo.

Para Christoffoli; Santos; Silva, e Dias o desenvolvimento sustentável (com melhor entendimento a partir dos anos 70), segundo estudos das escolas do pensamento ecológico, implica melhor condição de vida para as novas gerações. O marco de referência histórica para expansão do turismo em nível mundial ocorreu após a $2^{\text {a }}$ Grande Guerra. E alguns anos depois (entre os anos 70 e 80 ) começaram a surgir as primeiras manifestações ao surgimento de movimentos ambientalistas.

(Christoffoli; Santos; Silva, e Dias, 2002, pág. 3)

Mudanças superficiais são providenciadas nos programas das disciplinas, visando abrir um espaço para a "questão ambiental". Em decorrência da predominante ignorância ambiental da maioria dos doutores e pesquisadores universitários, o ambientalismo avança de forma lenta e fragmentada nas universidades, que tradicionalmente têm se mostrado conservadoras (particularmente no Brasil).

O Brasil começa a transformar-se no palco dos debates da conferência Rio-92 por meio dos preparativos do Fórum Global, realizados pelas Organizações não Governamentais e pelos movimentos sociais. As Universidades, de um modo geral, começam a perceber a falta de investimentos em educação ambiental e num enfoque tanto inter quanto transdisciplinar.

O ambientalismo autônomo que, ao lado do ambientalismo acadêmico, dá origem a um ambientalismo multissetorial, vê-se tomado de perplexidade durante e após a Rio-92. O ambientalismo empresarial, que tanto resistiu a investir na prevenção da poluição, descobre finalmente que pode fazer matéria-prima desta e obter novos mercados na medida em que os consumidores se tornam mais seletivos. Os empresários tomam as rédeas do processo de "conscientização ambiental", deixando na sombra os demais setores. 
O ambientalismo toma assim, desde a Rio-92, um rumo setorial, afunilando-se em torno das prioridades propostas pelo setor empresarial. Se, por um lado, isto significa um certo avanço ideológico dentro do liberalismo que redescobre o potencial da natureza, por outro lado representa um declínio do ambientalismo como um todo. Isto por representar um processo que se resume em um afunilamento e na dispersão. Afunilamento das prioridades na agenda pública, com força crescente dos empresários; e dispersão das ações efetivas em educação ambiental e lutas dos diversos setores do ambientalismo. 


\section{C) CARACTERIZAÇÃo GEOGRÁFICA DE SÃo JOÃO D’ALIANÇA}

\section{C.1) Localização Geográfica - Goiás}

Localizado na região Centro-Oeste do país, o Estado de Goiás está situado no Planalto Central do território brasileiro, posiciona-se entre os paralelos $12^{\circ} 23^{\prime} 46^{\prime}$ ' e $19^{\circ}$ 29’ 46” ao sul da linha do equador e os meridianos 45 58' $36^{\prime \prime}$ e $53^{\circ} 14^{\prime} 53^{\prime \prime}$ a oeste da linha de Greenwich, perfazendo uma área total de 341.289,50 $\mathrm{Km}^{2}$. Limita-se ao Norte com o Estado de Tocantins, a Leste com os Estados de Minas Gerais e Bahia, a Oeste com o Estado do Mato Grosso e ao Sul com os Estados de Minas Gerias e Mato Grosso do Sul. A área do Estado de Goiás compreende 4,19\% do território brasileiro e 22,22\% da região Centro-Oeste.

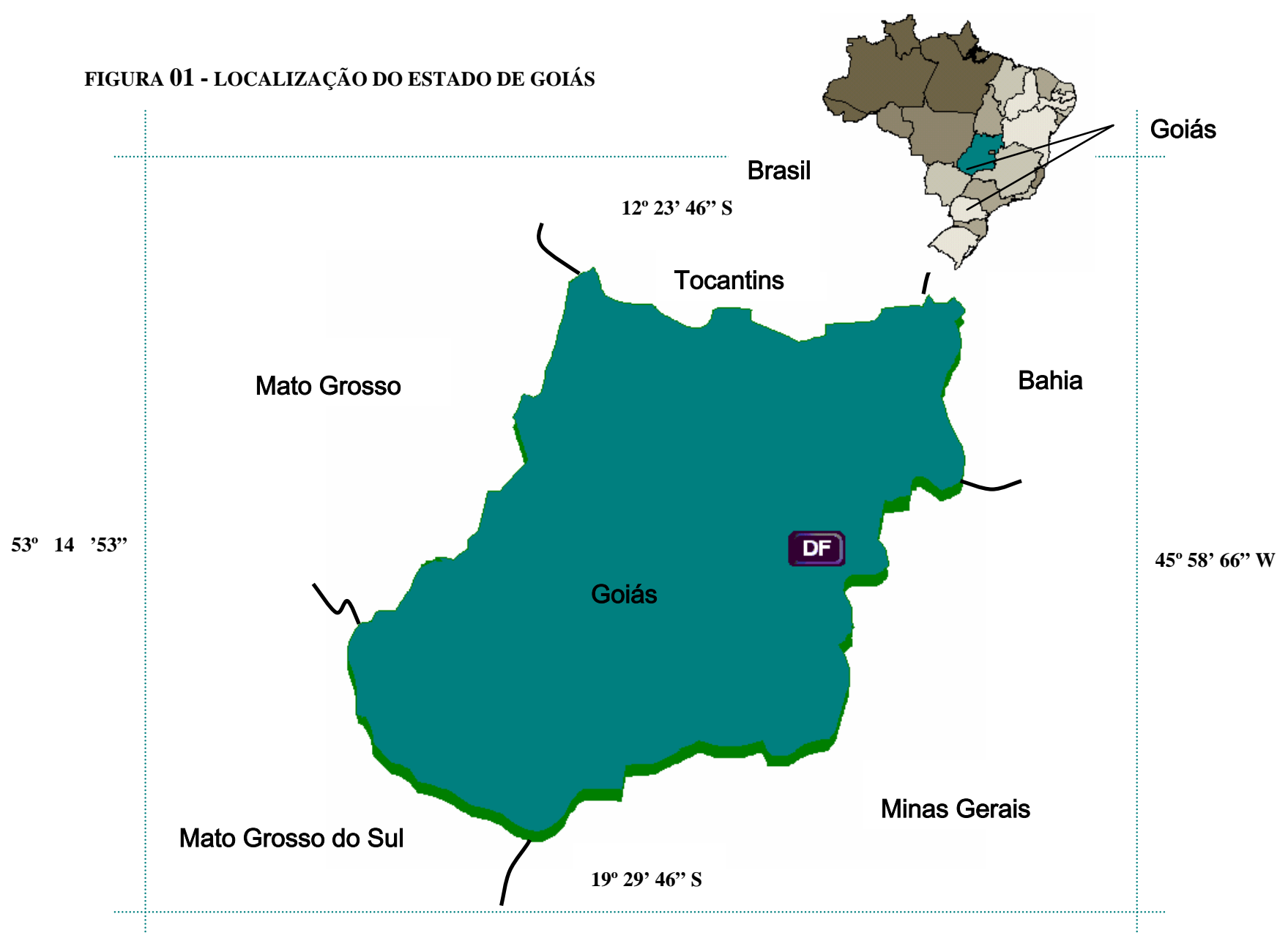




\section{C.2) Localização Geográfica - Nordeste Goiano}

O Nordeste do Estado de Goiás está localizado geograficamente na região de confluência com os estados de Minas Gerais, Bahia e Tocantins, entre os paralelos $12^{\circ} 30^{\prime}$ e $15^{\circ} 30^{\prime} \mathrm{S}$ e meridianos $45^{\circ} 30^{\prime}$ e $48^{\circ} 30^{\prime}$ a oeste de Greenwich, cujo polígono encerra uma área total de $38.766 \mathrm{~km}^{2}$, ou 3.876.600 hectares. A área da região Nordeste do Estado de Goiás compreende 11,36\% da área total do Estado de Goiás.

\section{C.3) Microrregiões do Nordeste Goiano}

A região Nordeste do Estado de Goiás é composta por um conjunto de vinte municípios, distribuídos em duas microrregiões oficialmente denominadas de "Vão do Paranã” (12 municípios) e “Chapada dos Veadeiros” (8 municípios). A região Nordeste do Estado de Goiás possui uma população de 147.986 habitantes de acordo com o último censo (ano 2000), representando 2,96\% da população total do Estado, com densidade demográfica de 3,80 habitantes por km²; distribuída conforme a Tabela 01.

\section{FIGURA 02 - MICRORREGIÕES DO NORDESTE GOIANO}
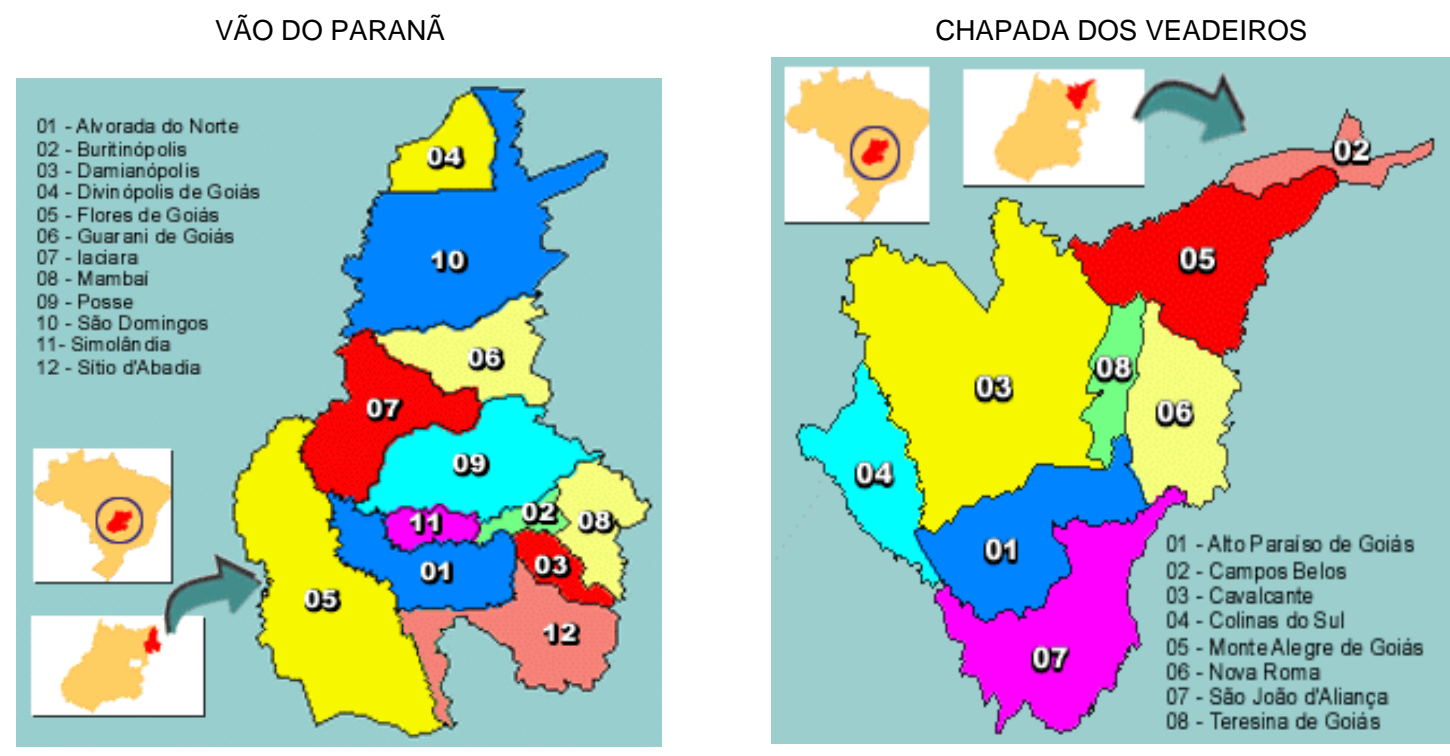

Fonte: <www.citybrazil.com.br> 
TABELA 01 - COMPOSIÇÃO DA REGIÃO NORDESTE DO ESTADO DE GOIÁS (2000)

\begin{tabular}{|c|c|c|c|c|c|c|}
\hline & Microrregiões & & & pulac & & \\
\hline & Chapada dos Veadeiros & Total & Urbana & $\%$ & Rural & $\%$ \\
\hline & Alto Paraíso de Goiás & 6.182 & 4.179 & 67,60 & 2.003 & 32,40 \\
\hline & Campos Belos & 17.047 & 14.207 & 83,34 & 2.840 & 16,66 \\
\hline & Cavalcante & 9.150 & 3.654 & 39,93 & 5.496 & 60,07 \\
\hline . & Colinas do Sul & 3.702 & 2.249 & 60,75 & 1.453 & 39,25 \\
\hline & Monte Alegre de Goiás & 6.892 & 2.746 & 39,84 & 4.146 & 60,16 \\
\hline & Nova Roma & 3.717 & 1.341 & 36,08 & 2.376 & 63,92 \\
\hline & São João D' Aliança & 6.736 & 4.188 & 62,17 & 2.548 & 37,83 \\
\hline & Teresina de Goiás & 2.585 & 1.775 & 68,67 & 810 & 31,33 \\
\hline & Vão do Paranã & Total & Urbana & $\%$ & Rural & $\%$ \\
\hline & Alvorada do Norte & 7.560 & 6.787 & 89,78 & 773 & 10,22 \\
\hline & Buritinópolis & 3.383 & 1.651 & 48,80 & 1.732 & 51,20 \\
\hline & Damianópolis & 3.303 & 1.502 & 45,47 & 1.801 & 54,53 \\
\hline & Divinópolis de Goiás & 5.172 & 2.993 & 57,87 & 2.179 & 42,13 \\
\hline 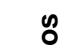 & Flores de Goiás & 7.514 & 2.225 & 29,61 & 5.289 & 70,39 \\
\hline 흥 & Guarani de Goiás & 4.678 & 1.708 & 36,51 & 2.970 & 63,49 \\
\hline ב & laciara & 11.295 & 7.998 & 70,81 & 3.297 & 29,19 \\
\hline & Mambaí & 4.838 & 3.017 & 62,36 & 1.821 & 37,64 \\
\hline & Posse & 25.696 & 18.388 & 71,56 & 7.308 & 28,44 \\
\hline & São Domingos & 9.636 & 4.434 & 46,01 & 5.202 & 53,99 \\
\hline & Simolândia & 6.219 & 5.199 & 83,60 & 1.020 & 16,40 \\
\hline & Sítio D' Abadia & 2.681 & 852 & 31,78 & 1.829 & 68,22 \\
\hline & Chapada dos Veadeiros & 56.011 & 34.339 & 61,31 & 21.672 & 38,69 \\
\hline & Vão do Paranã & 91.975 & 56.754 & 61,71 & 35.221 & 38,29 \\
\hline & Nordeste Goiano & 147.986 & 91.093 & 61,56 & 56.893 & 38,44 \\
\hline & Goiás & 5.003 .228 & 4.396.645 & 87,88 & 606.583 & 12,12 \\
\hline & \% Nordeste Goiano & $2,96 \%$ & $2,07 \%$ & & $9,38 \%$ & \\
\hline
\end{tabular}

Fonte: Secretaria do Planejamento e Desenvolvimento do Estado de Goiás

Superintendência de Estatística, Pesquisa e Informação 


\section{C.4) Microrregião da Chapada dos Veadeiros}

A microrregião da Chapada dos Veadeiros, em Goiás, compreende um total de oito municípios. É uma localidade preservada de belezas únicas no Brasil. O potencial turístico regional -ainda que de forma incipiente - já é reconhecido no país e no exterior.

O Parque Nacional da Chapada dos Veadeiros é o de maior importância do Planalto Central, sendo a cidade de Alto Paraíso a mais conhecida e centralizada cidade da microrregião mencionada. A região possui ainda um grande lago artificial (Lago Serra da Mesa), o qual envolve as áreas de vários municípios e, ainda há um conjunto de pequenas lagoas em uma zona de acesso restrito, são as chamadas Sete Lagoas.

Dentro do Parque Nacional da Chapada há algumas fontes e uma pequena lagoa de água termal (Águas Quentes), além disto, há nas proximidades deste Parque, barragens particulares que estão abertas a visitação do público. O Parque Nacional da Chapada foi criado em janeiro de 1961 pelo então Presidente da República Juscelino Kubitschek. Ocupava uma área de 6.250 km², com o nome de Parque Nacional do Tocantins.

Em maio de 1972, recebeu o nome atual e teve a área preservada reduzida para $1.720 \mathrm{~km}^{2}$. Em julho de 1981, sofreu mais uma redução, para $600 \mathrm{~km}^{2}$. Nove anos depois, a área foi aumentada para $650 \mathrm{~km}^{2}$ e, em outubro de 2001, chegou aos atuais $2.410 \mathrm{~km}^{2}$. Uma das áreas incluídas no novo parque é o Complexo do Macaco, região repleta de nascentes, riachos e cachoeiras localizada no município de São João d’ Aliança.

Conforme Cavalcanti, o recente aumento do parque foi motivado pela imposição da UNESCO de uma área mais ampla para que se realizasse a concessão do título de Patrimônio Natural da Humanidade para o Parque Nacional da Chapada dos Veadeiros. Para proteger a região em torno do Parque Nacional da Chapada dos Veadeiros, foi criada em 01/10/2000, pelo Estado de Goiás, a Área de Proteção Ambiental Pouso Alto, com mais de 800 mil hectares, envolvendo parte dos municípios de Alto Paraíso, Cavalcante, São João d'Aliança e Colinas do Sul. O nome da APA vem da Serra do Pouso Alto, na Chapada dos Veadeiros, um sítio histórico da época colonial. 
TABELA 02 - EVOLUÇÃO DAS POPULAÇõES URBANA E RURAL - GOIÁS, BRASIL

\begin{tabular}{|c|c|c|c|c|c|}
\hline \multirow{2}{*}{ Especificação } & \multicolumn{3}{|c|}{1970} & \multicolumn{2}{|r|}{1980} \\
\hline & Total & Urbana & Rural & Total & Urbana \\
\hline Goiás & 2.417 .466 & 1.108.248 & 1.309 .218 & 3.120 .718 & 2.108 .049 \\
\hline Brasil & 93.139 .037 & 52.084 .984 & 41.054 .053 & 119.002 .706 & 80.436 .409 \\
\hline \multirow{2}{*}{ Especificação } & \multicolumn{3}{|c|}{1996} & \multicolumn{2}{|r|}{2000} \\
\hline & Total & Urbana & Rural & Total & Urbana \\
\hline Goiás & 4.515 .868 & 3.873 .722 & 642.146 & 5.003 .228 & 4.396 .645 \\
\hline Brasil & 157.079 .573 & 123.082 .167 & 33.997 .406 & 169.799 .170 & 137.953 .959 \\
\hline \multicolumn{6}{|c|}{$\begin{array}{l}\text { Fonte: Fundação Instituto Brasileiro de Geografia e Est } \\
\text { Censos Demográficos 1970, 1980, 1991, } 2000 \\
\text { Contagem Populacional 1996 }\end{array}$} \\
\hline \multicolumn{6}{|c|}{ Participação da população rural na população total } \\
\hline Região & 1970 & 1980 & 1991 & 1996 & 2000 \\
\hline Goiás & $54,16 \%$ & $32,45 \%$ & $19,19 \%$ & $14,22 \%$ & $12,12 \%$ \\
\hline Brasil & $44,08 \%$ & $32,41 \%$ & $24,41 \%$ & $21,64 \%$ & $18,75 \%$ \\
\hline
\end{tabular}

\begin{tabular}{r|r|r}
\multicolumn{3}{c}{1991} \\
\multicolumn{1}{c|}{ Total } & \multicolumn{1}{c}{ Urbana } & \multicolumn{1}{c}{ Rural } \\
\hline 4.018 .903 & 3.247 .676 & 771.227 \\
146.825 .475 & 110.990 .990 & 35.834 .485 \\
\hline
\end{tabular}

Cáculos do Autor

Caculos do Autor

\section{Populaça urb}

140.000 .000

120.000 .000

100.000 .000

80.000 .000

60.000 .000

40.000 .000

20.000 .000

$0+1970$

População urbana e rural - Brasil

Gráfico 1. População Urbana e Rural-Brasil $(1970-2000)$

\begin{tabular}{l|r|r|r|r}
\multicolumn{7}{c}{ Variação da população rural } \\
\hline \multicolumn{1}{c|}{ Região } & $\mathbf{1 9 7 0 - 1 9 8 0}$ & $\mathbf{1 9 8 0}-\mathbf{1 9 9 1}$ & $\mathbf{1 9 9 1 - 1 9 9 6}$ & $\mathbf{1 9 9 6 - \mathbf { 2 0 0 0 }}$ \\
\hline Goiás & $-22,65 \%$ & $-23,84 \%$ & $-16,74 \%$ & $-5,54 \%$ \\
Brasil & $-6,06 \%$ & $-7,08 \%$ & $-5,13 \%$ & $-6,33 \%$ \\
\hline Cáculos do Autor
\end{tabular}

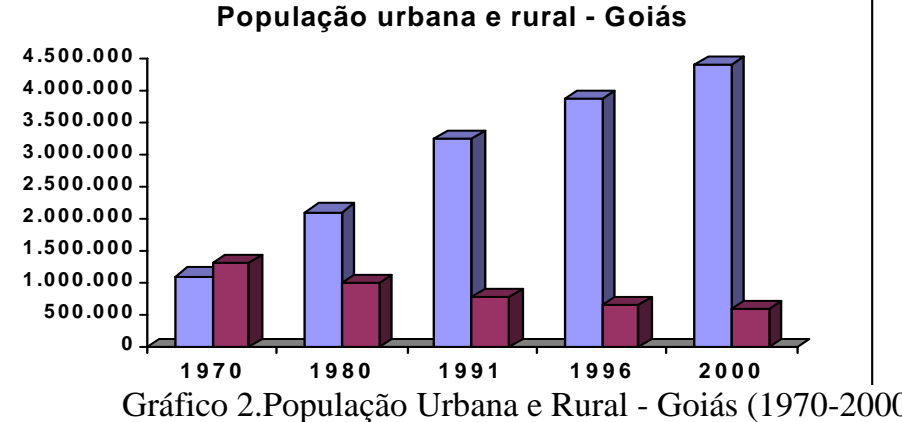




\section{C.5) Município de São João d’Aliança}

São João d'Aliança está localizado na microrregião da Chapada dos Veadeiros no Estado de Goiás. Está a apenas 150 Km de Brasília. O município, situado entre os paralelos $14^{\circ}$ e $15^{\circ} \mathrm{N}$, tem extensão territorial de $3.757 \mathrm{Km}^{2}$. Sua altitude varia entre 600 e 1.280 metros, com mediana em torno de 1.000 metros.

As estações climáticas são bem definidas; seca de maio a setembro e chuvosa de outubro a abril. A topografia é marcada pela presença da Serra Geral do Paranã que atravessa o município de Norte a Sul formando uma área de transição de características peculiares entre cerrados e florestas úmidas pré-amazônicas. Seus principais rios, ribeirões e córregos (Paranã, Tocantinzinho, Cachoeirinha e Brancas) - afluentes do rio Tocantins oferecem uma grande riqueza de imponentes cachoeiras e de belas corredeiras com condições privilegiadas para o ecoturismo e para a prática de esportes radicais (trilhas pedestres, trilhas cavaleiras, rapel, escaladas, vôo livre, canoagem, rafting, entre outras modalidades esportivas).

A atual sede do município surgiu no início do século 20, como povoado de trabalhadores provenientes da Fazenda Olhos d' Água às margens do Ribeirão Capetinga. Em 1910 era um arraial conhecido como Capetinga e tinha uma capela dedicada a São João Batista. Em 1913 passou a categoria de vila com o nome de São João da Capetinga. Era parte do distrito do Forte (povoado que hoje é distrito de São João d'Aliança) no município de Formosa. Nessa época surgem as primeiras tropas de carros de bois e cavalos, que iam de Formosa a Catalão, adquirindo gado e vendendo mercadorias. Estas viagens duravam meses.

A Coluna Prestes atravessou o município, passando por estas mesmas trilhas cavaleiras, entre 11 e 20 de setembro de 1926. A cidade de São João d'Aliança recebeu esse nome pelo fato da mesma ter acolhido nos anos 30 os revolucionários da Aliança Liberal. Com a campanha eleitoral da Aliança Liberal, uma comitiva de políticos, visitou por várias vezes a vila de São João da Capetinga - em um desses encontros Teotônio Fernandes e Nereu Ramos - políticos da época - proclamaram a mudança de nome da vila para São João da Aliança, pelo motivo de ser este local o ponto de apoio da Aliança Liberal na região. 
O ribeirão da Capetinga também foi rebatizado com o nome Ribeirão das Brancas em homenagem às belas mulheres que ali se banhavam. Em 22 de Abril de 1931, São João d'Aliança é elevada à categoria de município, mas entre 1939 a 1953 é reintegrado ao município de Formosa.

A segunda emancipação se deu em 13 de novembro de 1953, sendo efetivada em 01/01/1954. Ainda iam se passar mais de três décadas antes que se iniciasse a implantação de rodovias, da energia elétrica, da telefonia, de fazendas de grãos e de outros núcleos de povoamento, que ligados às crenças sobre a Chapada dos Veadeiros, marcaram não apenas a próxima cidade de Alto Paraíso, mas também o município de São João d’Aliança.

Cortado pela GO-118, o município de São João d’Aliança (GO) ganhou importância para o ecoturismo a partir da década de 90, com a ascensão de Alto Paraíso de Goiás como pólo turístico e por ser ponto de passagem obrigatória para o Parque Nacional da Chapada dos Veadeiros.

Várias reservas ecológicas particulares e hotéis-fazenda disputam hoje a preferência de quem vem de Brasília e não quer chegar até o maior movimento encontrado em Alto Paraíso. Há belas cachoeiras no município, como a do Mingau, além de trilhas e rios, como o Cachoeirinha e o rio Tocantinzinho, um dos formadores do lago artificial de Serra da Mesa, um dos maiores lagos artificiais do Brasil.

Uma das mais belas cachoeiras do município de São João D’ Aliança (GO) situa-se no rio das Brancas, dentro de uma fazenda que será transformada em uma Reserva Particular do Patrimônio Natural (RPPN). O acesso é difícil, exigindo contato com a gerência da Fazenda Mingau, que fica a $18 \mathrm{~km}$ por estrada de terra, entrando-se à esquerda - sendo o referencial de origem Brasília - da rodovia GO-118, logo após a sede do município. Há um grande volume de água, o que exige cuidados especiais, não sendo permitido o acesso para quem não sabe nadar. Está dentro de uma área de mata ciliar, constam, ainda, notícias da presença de onças na região.

A flutuação populacional do município de São João d’Aliança é percebida com a chegada de fazendeiros e de assentamentos. Este teve sua população acrescida em 17,83\% no período de 1980 a 1991 e novo aumento populacional de 16,54\% foi obtido no período de 1991 a 1996. Percebe-se também que, embora o crescimento populacional seja obtido nos demais períodos, a aceleração deste aumento vem diminuindo com o tempo. A 
população do município voltou a crescer nos períodos de 1996 a 2000 e entre 2000 e 2001, com respectivamente 12,98\% e 5,58 \% respectivamente nestes dois períodos.

Uma análise histórica macro da microrregião que engloba o município de São João d'Aliança, demonstra que a distribuição das populações urbana e rural para o Estado de Goiás (Tabela 02), em comparação com a região da Chapada dos Veadeiros também pode ser verificada (Tabela 04). Mostra que, enquanto a população rural no Estado, no ano de 1980, atingia 32,45\% do total da população, a microrregião da Chapada dos Veadeiros apresentava, no mesmo período, $69,71 \%$ de sua população residindo na zona rural.

Para o ano de 1991 a população rural do Estado de Goiás alcançou 19,19\% do total de habitantes, contra 51,34\% da população total da microrregião da Chapada residindo na zona rural. No ano de 1996 a população rural do Estado de Goiás representava 14,22\% do total, enquanto que a população rural da Chapada dos Veadeiros decrescia para o patamar de 42,63\% do total da população da região. Em 2000 a mencionada população do campo do Estado de Goiás representava 12,12\%, enquanto que a na Chapada atingia 38,69\% da população chapadeira - modo como os nativos se autodenominam.

Entretanto, ao analisar-se os dados da Tabela 05, constatamos que a população rural dos municípios da microrregião da Chapada diminuiu sistematicamente ao longo das décadas de 1980 e 1990. Apesar do decrescimento, em termos absolutos, da população rural do Estado de Goiás, houve aumento da participação relativa da população rural da microrregião em comparativo com o restante do Estado de Goiás. Conforme os dados da Tabela 04, a população rural da Chapada aumentou sua participação relativa para 2,74\%, 3,31\% e 3,57\%, nos anos de 1980, 1991 e 2000, respectivamente, em relação à população rural do Estado de Goiás. 
TABELA 03 - VARIAÇÃO PERCENTUAL DA POPULAÇÃO DA CHAPADA DOS VEADEIROS (1980-2001)

\begin{tabular}{|c|c|c|c|c|c|c|c|c|c|}
\hline \multirow{2}{*}{ Municípios } & \multicolumn{9}{|c|}{ População } \\
\hline & $1980^{a}$ & $-\quad V \%$ & 1991 & $\mathrm{~V} \%$ & 1996 & V\% & 2000 & V\% & 2001 \\
\hline Chapada dos Veadeiros & 28.656 & 45,06 & 41.567 & 3,87 & 43.176 & 8,53 & 46.861 & 1,71 & 47.662 \\
\hline Alto Paraíso de Goiás & 2.725 & 53,87 & 4.193 & 29,12 & 5.414 & 14,19 & 6.182 & 3,79 & 6.416 \\
\hline Campos Belos & 10.130 & 45,87 & 14.746 & 4,38 & 15.392 & 10,75 & 17.047 & 1,57 & 17.315 \\
\hline Colinas do Sul & - & - & 3.458 & 0,32 & 3.469 & 6,72 & 3.702 & 0,84 & 3.733 \\
\hline Monte Alegre de Goiás & 7.342 & 8,50 & 7.966 & $-13,53$ & 6.888 & 0,06 & 6.892 & $-1,68$ & 6.776 \\
\hline Nova Roma & 4.117 & 14,53 & 4.715 & $-15,27$ & 3.995 & $-6,96$ & 3.717 & $-3,93$ & 3.571 \\
\hline São João D’Aliança & 4.342 & 17,83 & 5.116 & 16,54 & 5.962 & 12,98 & 6.736 & 5,58 & 7.112 \\
\hline Teresina de Goiás & - & - & 1.373 & 49,75 & 2.056 & 25,73 & 2.585 & 5,96 & 2.739 \\
\hline
\end{tabular}

Fonte: Secretaria do Planejamento e Desenvolvimento do Estado de Goiás - Superintendência de Estatística, Pesquisa e Informação

Fundação Instituto Brasileiro de Geografia e Estatística - FIBGE 
TABELA 04 - PARTICIPAÇÃO POPULACIONAL URBANA E RURAL (\%): CHAPADA DOS VEADEIROS (1980-2000)

\begin{tabular}{|c|c|c|c|c|c|c|c|c|c|c|c|c|c|c|c|c|c|c|c|c|c|}
\hline \multirow{3}{*}{ Municípios } & \multicolumn{21}{|c|}{ População } \\
\hline & \multicolumn{5}{|c|}{ Total } & \multicolumn{8}{|c|}{ Urbana } & \multicolumn{8}{|c|}{ Rural } \\
\hline & 1980 & 1991 & 1996 & 2000 & 2001 & \multicolumn{2}{|c|}{$1980-\% \mathrm{~T}$} & \multicolumn{2}{|c|}{$1991-\% \mathrm{~T}$} & \multicolumn{2}{|c|}{$1996-\% T$} & \multicolumn{2}{|c|}{$2000-\% T$} & \multicolumn{2}{|c|}{$1980-\% \mathrm{~T}$} & \multicolumn{2}{|c|}{$1991-\% \mathrm{~T}$} & \multicolumn{2}{|c|}{$1996-\% \top$} & \multicolumn{2}{|c|}{$2000-\% T$} \\
\hline Chapada (CV) & 39.852 & 49.723 & 52.686 & 56.011 & 56.915 & 12.071 & 30,29 & 24.195 & 48,66 & 30.227 & 57,37 & 34.339 & 61,31 & 27.781 & 69,71 & 25.528 & 51,34 & 22.459 & 42,63 & 21.672 & 38,69 \\
\hline Alto Paraíso de Goiás & 2.725 & 4.193 & 5.414 & \begin{tabular}{l|l}
6.182 \\
\end{tabular} & 6.416 & 539 & 19,78 & 2.331 & 55,59 & 3.457 & 63,85 & 4.179 & 67,60 & 2.186 & 80,22 & 1.862 & 44,41 & 1.957 & 36,15 & 2.003 & \begin{tabular}{|l|l}
3 & 32,40
\end{tabular} \\
\hline Campos Belos & 10.130 & 14.746 & 15.392 & 17.047 & 17.315 & 6.892 & 68,04 & 11.728 & 79,53 & 12.809 & 83,22 & 14.207 & 83,34 & 3.238 & 31,96 & 3.018 & 20,47 & 2.583 & 16,78 & 2.840 & $\begin{array}{ll}0 & 16,66\end{array}$ \\
\hline Cavalcante & 11.196 & 8.156 & 9.510 & 9.150 & 9.253 & 1.802 & 16,10 & 2.001 & 24,53 & 3.062 & 32,20 & 3.654 & 39,93 & 9.394 & 83,90 & 6.155 & 75,47 & 6.448 & 67,80 & 5.496 & $\begin{array}{ll}6 & 60,07\end{array}$ \\
\hline Colinas do Sul & & 3.458 & 3.469 & 3.702 & 3.733 & - & - & 1.173 & 33,92 & 1.821 & 52,49 & 2.249 & 60,75 & - & - & 2.285 & 66,08 & 1.648 & 47,51 & 1.453 & $\begin{array}{ll}3 & 39,25\end{array}$ \\
\hline Monte Alegre de Goiás & 7.342 & 7.966 & 6.888 & 6.892 & 6.776 & 1.097 & 14,94 & 2.275 & 28,56 & 2.582 & 37,49 & 2.746 & 39,84 & 6.245 & 85,06 & 5.691 & 71,44 & 4.306 & 62,51 & 4.146 & $\begin{array}{ll}6 & 60,16\end{array}$ \\
\hline Nova Roma & 4.117 & 4.715 & 3.995 & 3.717 & 3.571 & 634 & 15,40 & 1.287 & 27,30 & 1.424 & 35,64 & 1.341 & 36,08 & 3.483 & 84,60 & 3.428 & 72,70 & 2.571 & 64,36 & 2.376 & $\begin{array}{ll}6 & 63,92\end{array}$ \\
\hline São João D`Aliança & 4.342 & 5.116 & 5.962 & 6.736 & 7.112 & 1.107 & 25,50 & 2.503 & 48,92 & 3.643 & 61,10 & 4.188 & 62,17 & 3.235 & 74,50 & 2.613 & 51,08 & 2.319 & 38,90 & 2.548 & $\begin{array}{ll}8 & 37,83\end{array}$ \\
\hline Teresina de Goiás & - & 1.373 & 2.056 & 2.585 & 2.739 & - & - & 897 & 65,33 & 1.429 & 69,50 & 1.775 & 68,67 & - & - & 476 & 34,67 & 627 & 30,50 & 810 & $\begin{array}{ll}0 & 31,33\end{array}$ \\
\hline \multirow{3}{*}{ Região } & \multicolumn{18}{|c|}{ População } & \multirow{2}{*}{\multicolumn{3}{|c|}{$\begin{array}{c}\text { Densidade } \\
\text { Demográfica }\end{array}$}} \\
\hline & \multicolumn{6}{|c|}{ Total } & \multicolumn{6}{|c|}{ Urbana } & \multicolumn{6}{|c|}{ Rural } & & & \\
\hline & \multicolumn{2}{|c|}{1980} & \multicolumn{2}{|c|}{1991} & \multicolumn{2}{|c|}{2000} & \multicolumn{2}{|c|}{1980} & \multicolumn{2}{|c|}{1991} & \multicolumn{2}{|c|}{2000} & \multicolumn{2}{|c|}{1980} & \multicolumn{2}{|c|}{1991} & \multicolumn{2}{|c|}{2000} & 1980 & 1991 & 2000 \\
\hline Goiás (GO) & \multicolumn{2}{|c|}{3.120 .718} & 4.018 & .903 & 5.003 & 228 & 2.108 & 3.049 & 3.247 & 7.676 & 4.396 & 6.645 & 1.012 & 2.669 & 771. & .227 & 606 & .583 & 9,14 & 11,78 & 14,66 \\
\hline Chapada (CV) & 39.8 & 352 & 49.7 & 23 & 56.0 & 11 & 12.0 & 071 & 24. & 195 & 34. & 339 & 27. & 781 & 25. & 528 & 21. & 672 & 1,40 & 1,75 & 1,97 \\
\hline Pop. relativa CV/GO & 1,28 & & 1,24 & & 1,12 & $2 \%$ & 0,5 & $7 \%$ & & $74 \%$ & 0,7 & $8 \%$ & & $4 \%$ & & $31 \%$ & & $57 \%$ & & & \\
\hline
\end{tabular}

Fonte: Secretaria do Planejamento e Desenvolvimento do Estado de Goiás - Superintendência de Estatística, Pesquisa e Informação

Fundação Instituto Brasileiro de Geografia e Estatística - Censo Demográfico

Superintendência Central de Planejamento - SEPLAN / GO - 1996 
Em que pese a evolução da participação relativa da população rural da localidade, deve-se levar em consideração que o critério adotado no Brasil para definição da população urbana e rural é o critério administrativo ${ }^{4}$.

Este critério preconiza que a sede do município é, por definição, uma cidade e que a população que habita a sede do município é considerada urbana. Além disto, o mencionado critério considera, ainda, que a sede de um distrito é uma vila e que a população residente nesta vila também é considerada urbana. Por este conceito a expansão da zona urbana, ou diminuição da zona rural, estaria determinada pela vontade do administrador público ou pela emancipação de um aglomerado populacional rural, situações que levariam ao surgimento de uma nova sede municipal e, portanto, uma nova zona urbana e conseqüente aumento de sua população.

Ao persistir o prevalecimento do critério Administrativo, a importância da população rural será exígua ou inexistente para promoção de políticas públicas, visto a insuficiência de seu valor absoluto. Neste aspecto está a importância desta questão para políticas públicas voltadas para o segmento econômico turismo. Observando-se a tendência da diminuição da população rural para o Brasil (Tabela 01) e em particular para o Estado de Goiás (Tabelas 01 e 04), poder-se-ia afirmar que não haveria propositura de políticas e projetos que contemplariam a dinamização do setor rural, em função de sua inexpressiva participação no cômputo da população total.

\footnotetext{
${ }^{4}$ Também conhecido como critério espacial, o critério administrativo separa o urbano do rural com base na idéia de que sempre há uma zona urbana. A mera existência de um município é suficiente para determinar um perímetro urbano.
} 
TABELA 05 - VARIAÇÃO POPULACIONAL URBANA E RURAL (\%): CHAPADA DOS VEADEIROS (1980-2000)

\begin{tabular}{|c|c|c|c|c|c|c|c|c|c|c|c|c|c|c|}
\hline \multirow{2}{*}{ Municípios } & \multicolumn{7}{|c|}{ Populacão Urbana } & \multicolumn{7}{|c|}{ Populacão Rural } \\
\hline & 1980 & V\% & 1991 & V\% & 1996 & V\% & 2000 & 1980 & V\% & 1991 & V\% & 1996 & V\% & 2000 \\
\hline Chapada (CV) & 12071 & 100,44 & 24.195 & 24,93 & 30.227 & 13,60 & 34.339 & 27.781 & $-8,11$ & 25.528 & $-12,02$ & 22.459 & $-3,50$ & 21.672 \\
\hline Alto Paraíso de Goiás & 539 & 332,47 & 2.331 & 48,31 & 3.457 & 20,89 & 4.179 & 2.186 & $-14,82$ & 1.862 & 5,10 & 1.957 & 2,35 & 2.003 \\
\hline Campos Belos & 6.892 & 70,17 & 11.728 & 9,22 & 12.809 & 10,91 & 14.207 & 3.238 & $-6,79$ & 3.018 & $-14,41$ & 2.583 & 9,95 & 2.840 \\
\hline Cavalcante & 1.802 & 11,04 & 2.001 & 53,02 & 3.062 & 19,33 & 3.654 & 9.394 & $-34,48$ & 6.155 & 4,76 & 6.448 & $-14,76$ & 5.496 \\
\hline Colinas do Sul & - & - & 1.173 & 55,24 & 1.821 & 23,50 & 2.249 & - & - & 2.285 & $-27,88$ & 1.648 & $-11,83$ & 1.453 \\
\hline Monte Alegre de Goiás & 1.097 & 107,38 & 2.275 & 13,49 & 2.582 & 6,35 & 2.746 & 6.245 & $-8,87$ & 5.691 & $-24,34$ & 4.306 & $-3,72$ & 4.146 \\
\hline Nova Roma & 634 & 103,00 & 1.287 & 10,64 & 1.424 & $-5,83$ & 1.341 & 3.483 & $-1,58$ & 3.428 & $-25,00$ & 2.571 & $-7,58$ & 2.376 \\
\hline São João D’Aliança & 1.107 & 126,11 & 2503 & 45,55 & 3.643 & 14,96 & 4.188 & 3.235 & $-19,23$ & 2613 & $-11,25$ & 2319 & 9,87 & 2548 \\
\hline Teresina de Goiás & - & - & 897 & 59,31 & 1.429 & 24,21 & 1.775 & - & - & 476 & 31,72 & 627 & 29,19 & 810 \\
\hline \multirow{3}{*}{$\begin{array}{c}\text { Variação da População } \\
\text { Urbana e Rural }(\% \text { Chapada } \\
\text { dos Veadeiros }\end{array}$} & \multicolumn{7}{|c|}{ População Urbana } & \multicolumn{7}{|c|}{ População Rural } \\
\hline & 1980 & $\%$ & 1991 & $\%$ & 1996 & $\%$ & 2000 & 1980 & $\%$ & 1.991 & $\%$ & 1.996 & $\%$ & 2.000 \\
\hline & 12.071 & 11,11 & 24.195 & 17,87 & 30.227 & 21,58 & 34.339 & 27.781 & 25,58 & 25.528 & 18,86 & 22.459 & 16,04 & 21.672 \\
\hline
\end{tabular}

Fonte: Secretaria do Planejamento e Desenvolvimento do Estado de Goiás - Superintendência de Estatística, Pesquisa e Informação 
O conceito de zona urbana e zona rural tem sido reavaliado por estudiosos e organizações de diversas nações ${ }^{5}$. A consciência das dinâmicas das atividades econômicas localizadas em territórios rurais reforça a necessidade de reavaliação do critério Administrativo e a proposta de um conceito de ruralidade.

Segundo Abromovay (2002, pág. 6), “ruralidade é um conceito de natureza territorial e não-setorial e o mesmo se aplica à noção de urbano. As cidades não são definidas pela indústria nem o campo pela agricultura”.

Apesar da relevância das atividades econômicas rurais e não rurais exercidas no meio rural $^{6}$, não basta caracterizar o tipo de atividade econômica predominante para definir uma região como rural ou urbana. A Organização de Cooperação e Desenvolvimento Econômico - OCDE, adota como critério, para classificar uma região como urbana ou rural, a densidade demográfica. De acordo com o referido critério, uma localidade é considerada urbana a partir de uma densidade demográfica de $150 \mathrm{hab} / \mathrm{Km}^{2}$. No intuito de adequar o valor do parâmetro à realidade brasileira, poder-se-ia adotar o valor de $20 \mathrm{hab} / \mathrm{Km}^{2}$, uma vez que este é o valor da densidade demográfica do Brasil ${ }^{7}$.

De acordo com os dados apresentados na Tabela 06, a microrregião da Chapada possuía, no ano de 2001, uma densidade demográfica de 2,00 hab $/ \mathrm{km}^{2}$. Conforme o parâmetro adotado (150 ou 20 hab/Km²), a microrregião da Chapada dos Veadeiros apresenta uma densidade demográfica 75 ou 10 vezes menor, respectivamente. São João d’Aliança tem densidade demográfica de 2,14 hab/ $\mathrm{Km}^{2}$, contrastando com a capital do Estado de Goiás - Goiânia - com 1.501,18 hab/Km².

\footnotetext{
${ }^{5}$ Sobre o assunto ver: ABROMOVAY (2000); SARRACENO (1996/1999); OCDE (1994); VON MEYER (1998); Plano para o Desenvolvimento Sustentável do Brasil Rural - PNDRS $1^{\mathrm{a}}$ e $2^{\mathrm{a}}$ versões (2002).

${ }^{6}$ As atividades econômicas não podem mais ser divididas em atividades circunscritas ao meio urbano ou rural, pois, as atividades econômicas sempre tiveram um caráter de complementaridade. A Revolução Industrial de 1740, a partir de inovações tecnológicas na indústria têxtil é, na verdade, uma revolução na agroindústria; uma relação de complementaridade entre a agricultura e a infante indústria. Outro exemplo é o chamado turismo rural; uma atividade não rural sendo exercida no meio rural.

${ }^{7}$ O parâmetro proposto é obtido pela divisão entre a população brasileira para o ano de 2000 (169.799.170) e a área total do Brasil $(8.514 .215,30)=19,94$ hab $/ \mathrm{km}^{2}$. Trata-se da densidade demográfica do Brasil, cerca de $20 \mathrm{hab} / \mathrm{km}^{2}$.
} 
TABELA 06 - DENSIDADE DEMOGRÁFICA - REGIÃO NORDESTE DO ESTADO DE GOIÁS (2001)

\begin{tabular}{|c|c|c|c|c|}
\hline \multicolumn{2}{|r|}{ Microrregiões } & \multirow{2}{*}{$\begin{array}{c}\text { Área }\left(\mathrm{Km}^{2}\right) \\
28.466,30\end{array}$} & \multirow{2}{*}{$\begin{array}{c}\text { Habitantes } \\
(2001)\end{array}$} & \multirow{2}{*}{$\begin{array}{c}\begin{array}{c}\text { Densidade } \\
\text { Demográfica }\end{array} \\
2,00\end{array}$} \\
\hline & Chapada dos Veadeiros & & & \\
\hline \multirow{8}{*}{$\frac{\stackrel{n}{0}}{\frac{0}{0}}$} & Alto Paraíso de Goiás & $2.593,90$ & 6.416 & 2,47 \\
\hline & Campos Belos & $7.852,80$ & 17.315 & 2,20 \\
\hline & Cavalcante & $6.953,50$ & 9.253 & 1,33 \\
\hline & Colinas do Sul & $1.708,20$ & 3.733 & 2,19 \\
\hline & Monte Alegre de Goiás & $3.119,80$ & 6.776 & 2,17 \\
\hline & Nova Roma & $2.136,00$ & 3.571 & 1,67 \\
\hline & São João D' Aliança & $3.327,40$ & 7.112 & 2,14 \\
\hline & Teresina de Goiás & 774,70 & 2.739 & 3,54 \\
\hline \multirow{13}{*}{$\frac{.0}{\frac{0}{0}}$} & Vão do Paranã & $17.389,30$ & 92.682 & 5,33 \\
\hline & Alvorada do Norte & $1.291,90$ & 7.571 & 5,86 \\
\hline & Buritinópolis & 268,20 & 3.420 & 12,75 \\
\hline & Damianópolis & 415,40 & 3.257 & 7,84 \\
\hline & Divinópolis de Goiás & 831,10 & 5.191 & 6,25 \\
\hline & Flores de Goiás & $3.709,30$ & 7.820 & 2,11 \\
\hline & Guarani de Goiás & $1.229,30$ & 4.570 & 3,72 \\
\hline & laciara & $1.625,40$ & 11.385 & 7,00 \\
\hline & Mambaí & 859,60 & 4.926 & 5,73 \\
\hline & Posse & $1.954,80$ & 26.060 & 13,33 \\
\hline & São Domingos & $3.295,70$ & 9.516 & 2,89 \\
\hline & Simolândia & 342,70 & 6.293 & 18,36 \\
\hline & Sítio D' Abadia & $1.565,90$ & 2.673 & 1,71 \\
\hline \multirow{3}{*}{\multicolumn{2}{|c|}{$\begin{array}{l}\text { Estado de Goiás } \\
\text { Região Nordeste do Estado de Goiás } \\
\text { Goiânia (capital) }\end{array}$}} & $341.289,00$ & 5.003 .228 & 14,66 \\
\hline & & $45.855,60$ & 149.597 & 3,26 \\
\hline & & 740,50 & 1.111 .622 & $1.501,18$ \\
\hline
\end{tabular}

Fonte: Secretaria do Planejamento e Desenvolvimento do Estado de Goiás

Superintendência de Estatística, Pesquisa e Informação

Ao levar-se em consideração a densidade demográfica de São João d’Aliança (2,14 hab/Km²) e o parâmetro adotado pela Organização de Cooperação e Desenvolvimento Econômico (150 hab/Km²) ou ainda, a média nacional (20 hab/Km²); pode-se afirmar que o município é eminentemente rural, apesar do predomínio da população urbana. Sendo assim, quaisquer propostas de desenvolvimento, principalmente no ramo turístico, devem levar em consideração a realidade rural do município, a especificidade da agropecuária e o ambiente sócio-cultural da região como fatores preponderantes do sucesso de políticas, programas e projetos destinados a alavancar a atividade turística desta localidade. Este é um dos fatores que determina o tipo de turismo que melhor pode se adequar às características locais. 


\section{C.5.1) Estatísticas do Município}

Na classificação dos municípios da microrregião da Chapada, como entes federativos eminentemente rurais, argumenta-se a impropriedade de se caracterizar um município em função da atividade econômica predominante. Porém, independente da dicotomia rural versus urbano, é fato a existência de alguma produção tipicamente do campo.

Os municípios que compõem a localidade produzem - basicamente - gêneros necessários à subsistência (Tabelas 07 e 08), que são utilizados pelos restaurantes e por todo o segmento gastronômico do turismo local - venda de pamonhas, doces, castanhas de frutos do cerrado como o baru, frutas desidratadas - mesmo que de forma ainda incipiente.

Há, no município de São João d' Aliança, locais onde se pode encontrar produtos gastronômicos do tipo artesanais. Há desde biscoitos caseiros e geléias de frutos do cerrado na Casa da Capetinga - sede da Agencia de Desenvolvimento da região da Reserva da Biosfera Goyaz, além de biscoitos caseiros feitos pelas donas de casa da comunidade que se encontram empacotados em um visual muito atrativo para consumidores mais exigentes. Nos bares e restaurantes do município pode-se encontrar doces que vão desde o tradicional Doce de Leite e do Doce de Ambrosia - doce de ovos típico de Goiás - até o exótico Doce de Buriti - outro fruto típico do cerrado.

TABELA 07 - MICRORREGIÃO CHAPADA DOS VEADEIROS: PRODUÇÃO ANIMAL (2000)

\begin{tabular}{|c|c|c|c|c|c|c|}
\hline Municípios & Ave (cab) & $\begin{array}{c}\text { Bovino } \\
\text { (cab) }\end{array}$ & \begin{tabular}{|c|} 
Produção \\
leite (1.000 \\
I)
\end{tabular} & $\begin{array}{c}\text { Produção } \\
\text { ovos } \\
\text { (1.000 dz) }\end{array}$ & $\begin{array}{c}\text { Suínos } \\
\text { (cab) }\end{array}$ & $\begin{array}{c}\text { Vacas } \\
\text { Ordenhadas } \\
\text { (cab) }\end{array}$ \\
\hline Alto Paraíso de Goiás & 12.550 & 21.000 & 1.030 & 33 & 1.090 & 1.700 \\
\hline Campos Belos & 13.100 & 40.085 & 701 & 25 & 1.700 & 3.500 \\
\hline Cavalcante & 43.900 & 43.300 & 1.208 & 100 & 3.710 & 3.300 \\
\hline Colinas do Sul & 14.000 & 25.000 & 1.800 & 42 & 1.400 & 2.000 \\
\hline Monte Alegre de Goiás & 19.500 & 96.718 & 1.100 & 34 & 2.100 & 4.000 \\
\hline Nova Roma & 16.000 & 37.974 & 400 & 22 & 1.970 & 1.100 \\
\hline São João D`Aliança & 25.000 & 57.000 & 2.000 & 70 & 2.550 & 2.900 \\
\hline Teresina de Goiás & 6.400 & 8.000 & 370 & 14 & 930 & 650 \\
\hline Total & 150.450 & 329.077 & 8.609 & 340 & 15.450 & 19.150 \\
\hline
\end{tabular}


TABELA 08 - MICRORREGIÃO CHAPADA DOS VEADEIROS: PRODUÇÃO VEGETAL - GRÃOS(2001)

\begin{tabular}{|c|c|c|c|c|c|c|c|c|c|c|}
\hline \multirow{2}{*}{ Municípios } & \multicolumn{2}{|c|}{ Feijão } & \multicolumn{2}{|c|}{ Arroz sequeiro } & \multicolumn{2}{|c|}{ Milho $1^{a}$ safra } & \multicolumn{2}{|c|}{ Soja } & \multicolumn{2}{|c|}{ Café } \\
\hline & Área (ha) & Produção (t) & Área (ha) & \begin{tabular}{|l|} 
Produção $(\mathrm{t})$ \\
\end{tabular} & Área (ha) & Produção (t) & Área (ha) & Produção (t) & Área (ha) & Produção (t) \\
\hline Alto Paraíso de Goiás & 300 & 360 & 400 & 400 & 750 & 1.500 & 4.000 & 8.400 & 45 & 45 \\
\hline Campos Belos & 50 & 10 & 330 & 165 & 800 & 480 & - & - & & - \\
\hline Cavalcante & 160 & 137 & 350 & 420 & 720 & 1.080 & - & - & 5 & 4 \\
\hline Colinas do Sul & 10 & 3 & 200 & 180 & 250 & 500 & - & - & - & - \\
\hline Monte Alegre de Goiás & 30 & 13 & 400 & 200 & 1.172 & 768 & - & - & - & - \\
\hline Nova Roma & 40 & 7 & 300 & 144 & 850 & 510 & - & - & - & - \\
\hline São João D`Aliança & 1.100 & 2.550 & 400 & 480 & 6.240 & 24.960 & 6.200 & 14.880 & 60 & 67 \\
\hline Teresina de Goiás & 15 & 9 & 80 & 80 & 150 & 180 & - & - & - & - \\
\hline Total & 1.705 & 3.089 & 2.460 & 2.069 & 10.932 & 29.978 & 10.200 & 23.280 & 110 & 116 \\
\hline
\end{tabular}

Fonte: Secretaria do Planejamento e Desenvolvimento do Estado de Goiás - Superintendência de Estatística, Pesquisa e Informação

TABELA 09 - CHAPADA DOS VEADEIROS: PRODUÇÃO VEGETAL - FRUTAS E CANA-DE-AÇÚCAR (2001) 


\begin{tabular}{|c|c|c|c|c|c|c|c|c|}
\hline \multirow{2}{*}{ Municípios } & \multicolumn{2}{|c|}{ Manga } & \multicolumn{2}{|c|}{ Laranja } & \multicolumn{2}{|c|}{ Banana } & \multicolumn{2}{|c|}{ Cana-de-açúcar } \\
\hline & Área (ha) & Produção (t) & Área (ha) & \begin{tabular}{l|} 
Produção (t) \\
\end{tabular} & Área (ha) & \begin{tabular}{|l|} 
Produção (t) \\
\end{tabular} & Área (ha) & Produção (t) \\
\hline Alto Paraíso de Goiás & 10 & 80 & 15 & 110 & 40 & 250 & 15 & 450 \\
\hline Campos Belos & - & - & - & - & 25 & 105 & 150 & 3.450 \\
\hline Cavalcante & - & - & - & - & 80 & 400 & 40 & 1.040 \\
\hline Colinas do Sul & - & - & - & - & 95 & 285 & 20 & 600 \\
\hline Monte Alegre de Goiás & - & - & - & - & 15 & 60 & 110 & 2.750 \\
\hline Nova Roma & - & & - & - & 55 & 220 & 190 & 4.750 \\
\hline São João D`Aliança & 10 & 36 & 75 & 600 & 27 & 216 & 60 & 1.800 \\
\hline Teresina de Goiás & - & - & - & - & 20 & 130 & 10 & 300 \\
\hline$\overline{\text { Total }}$ & 20 & 116 & 90 & 710 & 357 & 1.666 & 595 & 15.140 \\
\hline
\end{tabular}

Fonte: Secretaria do Planejamento e Desenvolvimento do Estado de Goiás - Superintendência de Estatística, Pesquisa e Informação 
A produção pecuária da microrregião da Chapada está basicamente restrita a bovinocultura, avicultura e suinocultura. Comparada com as outras microrregiões do Estado de Goiás, a Chapada apresenta uma baixa participação relativa no total do efetivo bovino (1,79\% - $18^{\circ}$ colocação dentro do ranking estadual), suíno (1,32\% - $17^{\circ}$ colocação) e avícola (0,57\% - $18^{\circ}$ colocação) (dados da Tabela 10). A pecuária bovina destaca-se como o principal rebanho na região; porém sua participação em relação ao rebanho bovino do Estado de Goiás apresenta uma tendência à diminuição no período de 1996 a 2000 (Tabela 11). No período em apreço, os municípios de Campos Belos e Monte Alegre de Goiás são os únicos que apresentam expressivo crescimento de seu rebanho bovino (60,77\% e 42,68\%; respectivamente).

No que diz respeito à produção agrícola, a microrregião da Chapada (Tabelas 08 e 09), apresenta um elevado déficit - em termos de produtividade - ao ser comparada com o rendimento agrícola médio do Estado de Goiás (Tabela 12). Conforme os dados da Tabela 12, a produção agrícola da localidade, apresenta déficit de produtividade variando de 0,50\% (Feijão $3^{\mathrm{a}}$ safra) até 231,98\% (Cana-de-açúcar).

O desenvolvimento da microrregião da Chapada passa obrigatoriamente pela diversificação das atividades econômicas rurais e não rurais. O turismo se mostra como uma atividade alternativa a atividade agropecuária na região com áreas ainda tão preservadas, fator básico para o alto potencial de sucesso do Ecoturismo. A produção animal e vegetal de uma localidade devem ser consideradas fatores de apoio ao turismo.

De acordo com os dados apresentados, a produção agropecuária de São João d'Aliança e da Chapada, em geral, carece de mecanismos endógenos de alavancagem da produção, produtividade e diversificação do produto interno para que se possa dar o suporte logístico necessário para a operacionalização da atividade turística na região. Esta perspectiva de dinamização da produção viabiliza-se pela articulação de cadeias produtivas, com a diversificação das atividades econômicas e com inserção dos agricultores familiares na economia local para a geração dos suprimentos necessários ao Turismo. A gastronomia típica do município e da região é um fator de atração turística por natureza. A tradicional comida goiana adicionada aos frutos típicos do cerrado não são ainda explorados pelo turismo de forma adequada. A criatividade do povo nativo da localidade é, por si só, um forte componente de atracão para o turismo local. 
TABELA 10 - GOIÁS: EFETIVO DE BOVINOS, SUÍNOS E AVES POR MICRORREGIÃO (2000)

\begin{tabular}{|c|c|c|c|c|c|c|c|c|c|}
\hline \multirow{2}{*}{ Microrregião } & \multicolumn{3}{|c|}{ Bovino } & \multicolumn{3}{|c|}{ Suínos } & \multicolumn{3}{|c|}{ Aves } \\
\hline & Cabeças & Part. \% & Ranking & Cabeças & Part. \% & Ranking & Cabeças & Part. \% & Ranking \\
\hline Anápolis & 774.258 & $4,21 \%$ & $10^{\circ}$ & 79.648 & $6,78 \%$ & $4^{0}$ & 3.178 .808 & $12,02 \%$ & $4^{0}$ \\
\hline Anicuns & 637.954 & $3,47 \%$ & $12^{\circ}$ & 58.070 & $4,94 \%$ & $9^{\circ}$ & 742.479 & $2,81 \%$ & $8^{\circ}$ \\
\hline Aragarças & 747.500 & $4,06 \%$ & $11^{\circ}$ & 28.010 & $2,39 \%$ & $16^{\circ}$ & 162.040 & $0,61 \%$ & $17^{\circ}$ \\
\hline Catalão & 595.053 & $3,23 \%$ & $15^{\circ}$ & 50.585 & $4,31 \%$ & $10^{\circ}$ & 1.373 .660 & $5,19 \%$ & $7^{0}$ \\
\hline Ceres & 1.000 .400 & $5,44 \%$ & $9^{\circ}$ & 75.510 & $6,43 \%$ & $6^{0}$ & 572.800 & $2,17 \%$ & $9^{\circ}$ \\
\hline Chapada dos Veadeiros & 329.077 & $1,79 \%$ & $18^{\circ}$ & 15.450 & $1,32 \%$ & $17^{\circ}$ & 150.450 & $0,57 \%$ & $18^{\circ}$ \\
\hline Entorno de Brasília & 1.225 .675 & $6,66 \%$ & 70 & 87.170 & $7,42 \%$ & $3^{0}$ & 2.538 .200 & $9,60 \%$ & $5^{0}$ \\
\hline Goiânia & 601.157 & $3,27 \%$ & $13^{\circ}$ & 79.144 & $6,74 \%$ & $5^{\circ}$ & 3.974 .146 & $15,03 \%$ & $2^{0}$ \\
\hline Iporá & 596.200 & $3,24 \%$ & $14^{\circ}$ & 40.980 & $3,49 \%$ & $12^{\circ}$ & 273.375 & $1,03 \%$ & $13^{\circ}$ \\
\hline Meia Ponte & 1.526 .412 & $8,30 \%$ & $3^{\circ}$ & 101.908 & $8,68 \%$ & $2^{0}$ & 1.499 .780 & $5,67 \%$ & $6^{0}$ \\
\hline Pires do Rio & 498.800 & $2,71 \%$ & $16^{\circ}$ & 46.750 & $3,98 \%$ & $11^{\circ}$ & 3.279 .530 & $12,40 \%$ & $3^{0}$ \\
\hline Porangatu & 1.390 .000 & $7,55 \%$ & $5^{0}$ & 66.890 & $5,70 \%$ & $8^{\circ}$ & 562.600 & $2,13 \%$ & $10^{\circ}$ \\
\hline Quininóplois & 1.372 .203 & $7,46 \%$ & $6^{0}$ & 40.860 & $3,48 \%$ & $13^{\circ}$ & 471.180 & $1,78 \%$ & $11^{\circ}$ \\
\hline Rio Vermelho & 1.558 .850 & $8,47 \%$ & $2^{0}$ & 39.725 & $3,38 \%$ & $14^{\circ}$ & 233.285 & $0,88 \%$ & $14^{\circ}$ \\
\hline São Miguel do Araguaia & 1.483 .470 & $8,06 \%$ & $4^{0}$ & 29.540 & $2,52 \%$ & $15^{\circ}$ & 172.242 & $0,65 \%$ & $15^{\circ}$ \\
\hline Sudoeste de Goiás & 2.598 .501 & $14,12 \%$ & $1^{0}$ & 250.540 & $21,33 \%$ & $1^{0}$ & 6.662 .640 & $25,19 \%$ & $1^{0}$ \\
\hline Vale do Rio dos Bois & 1.005 .352 & $5,46 \%$ & $8^{\circ}$ & 68.430 & $5,83 \%$ & $7^{0}$ & 424.300 & $1,60 \%$ & $12^{\circ}$ \\
\hline Vão do Paranã & 458.360 & $2,49 \%$ & $17^{\circ}$ & 15.150 & $1,29 \%$ & $18^{\circ}$ & 172.900 & $0,65 \%$ & $16^{\circ}$ \\
\hline Total Estado & 18.399 .222 & $100,00 \%$ & & 1.174 .360 & $100,00 \%$ & & 26.444 .415 & $100,00 \%$ & \\
\hline Região Nordeste - GO & 787.437 & $4,28 \%$ & & 30.600 & $2,61 \%$ & & 323.350 & $1,22 \%$ & \\
\hline
\end{tabular}

Fonte:Fundação Instituto Brasileiro de Geografia e Estatística- IBGE

Elaboração: SEPLAN-GO/SEPIN/Gerência de Estatísticas Socioeconômicas - 2002 


\begin{tabular}{l|r|r|r}
\hline \multirow{2}{*}{ Municípios } & \multicolumn{3}{c}{ Total de Bovinos } \\
\cline { 2 - 4 } & \multicolumn{1}{c|}{$\mathbf{1 9 9 6}$} & \multicolumn{1}{c}{$\mathbf{2 0 0 0}$} & \multicolumn{1}{c}{ V \% } \\
\hline Alto Paraíso de Goiás & 18.104 & 21.000 & 16,00 \\
Campos Belos & 24.933 & 40.085 & 60,77 \\
Cavalcante & 40.525 & 43.300 & 6,85 \\
Colinas do Sul & 23.634 & 25.000 & 5,78 \\
Monte Alegre de Goiás & 67.788 & 96.718 & 42,68 \\
Nova Roma & 40.426 & 37.974 & $-6,07$ \\
São João d'Aliança & 52.578 & 57.000 & $\mathbf{8 , 4 1}$ \\
Teresina de Goiás & 8.572 & 8.000 & $-6,67$ \\
\hline \hline Goiás & $\mathbf{1 6 . 4 8 8 . 3 9 0}$ & $\mathbf{1 8 . 3 9 9 . 2 2 2}$ & $\mathbf{1 1 , 5 9}$ \\
\hline Chapada dos Veadeiros - GO & $\mathbf{2 7 6 . 5 6 0}$ & $\mathbf{3 2 9 . 0 7 7}$ & $\mathbf{1 8 , 9 9}$ \\
\hline Participação Relativa & $\mathbf{1 , 6 8 \%}$ & $\mathbf{1 , 7 9 \%}$ & $\mathbf{6 , 6 3}$ \\
\hline
\end{tabular}

Fonte: Fundação Instituto Brasileiro de Geografia e Estatística - IBGE, 1995-1996

Secretaria do Planejamento e Desenvolvimento - Superintendência de Estatística, Pesquisa e Informação.

TABELA 12 - PRODUÇÃO AGRÍCOLA: DÉFICIT DE PRODUTIVIDADE (2001)

\begin{tabular}{|c|c|c|c|c|c|c|c|}
\hline \multirow{2}{*}{$\begin{array}{c}\text { Produção } \\
\text { Agrícola }\end{array}$} & \multicolumn{3}{|c|}{ Região Nordeste Goiano } & \multicolumn{3}{|c|}{ Estado de Goiás } & \multirow{2}{*}{$\begin{array}{c}\text { Déficit de } \\
\text { Produtivi- } \\
\text { dade }\end{array}$} \\
\hline & Área (ha) & Produção (t) & $\begin{array}{c}\text { Rendimento médio } \\
(\mathrm{kg} / \mathrm{ha})\end{array}$ & Área (ha) & Produção (t) & \begin{tabular}{|c|} 
Rendimento médio \\
$(\mathrm{kg} / \mathrm{ha})$
\end{tabular} & \\
\hline Banana & 551 & 3.611 & $6.553,54$ & 13.013 & 152.055 & $11.684,85$ & $78,30 \%$ \\
\hline Café & 115 & 121 & $1.052,17$ & 5.559 & 10.731 & $1.930,38$ & $83,47 \%$ \\
\hline Cana-de-açúcar & 1.722 & 40.937 & $23.772,94$ & 129.921 & 10.253 .497 & $78.921,01$ & $231,98 \%$ \\
\hline Feijão $1^{a}$ safra & 1.370 & 1.376 & $1.004,38$ & 40.035 & 66.303 & $1.656,13$ & $64,89 \%$ \\
\hline Feijão $2^{\mathrm{a}}$ safra & 140 & 96 & 685,71 & 49.705 & 64.106 & $1.289,73$ & $88,09 \%$ \\
\hline Feijão $3^{a}$ safra & 900 & 2.227 & $2.474,44$ & 36.726 & 91.333 & $2.486,88$ & $0,50 \%$ \\
\hline Laranja & 94 & 774 & $8.234,04$ & 6.643 & 119.954 & $18.057,20$ & $119,30 \%$ \\
\hline Mandioca & 1.060 & 13.740 & $12.962,26$ & 16.666 & 248.568 & $14.914,68$ & $15,06 \%$ \\
\hline Milho $1^{\mathrm{a}}$ safra & 24.312 & 44.514 & $1.830,95$ & 738.249 & 3.493 .540 & $4.732,20$ & $158,46 \%$ \\
\hline Soja & 11.400 & 25.030 & $2.195,61$ & 1.538 .988 & 4.052.169 & $2.633,01$ & $19,92 \%$ \\
\hline
\end{tabular}

Dada a dimensão média das propriedades da região Nordeste Goiano ${ }^{8}$, seria necessária a implementação de programas e projetos específicos para a região criar uma estrutura adequada ao atendimento das necessidades do turismo com menores impactos sobre a cultura da população local. Poder-se-ia questionar o porque da ausência de uma estrutura sócio-produtiva de exploração sustentável de frutos nativos, formando uma

\footnotetext{
${ }^{8}$ Sobre a estrutura fundiária da região Nordeste do Estado de Goiás, consulte ESTRUTURA FUNDIÁRIA, TABELA 21.
} 
cadeia produtiva que contemplasse do plantio até a distribuição da produção, priorizando de forma integrada as organizações sociais. Esta atividade seria complementar ao ecoturismo - visto que os produtos resultantes deste segmento constituem-se em matériasprimas destinadas ao preparo de alimentação que será utilizada na gastronomia local.

Neste aspecto a agricultura familiar assume um papel de extrema relevância para a existência de uma atividade turística. Segundo o professor Paulo Haddad (1999, pág. 21), “os grupos sociais indicam o objetivo real que é atingido por diferentes alternativas de desenvolvimento regional. As características regionais (grau de urbanização, distribuição fundiária entre outras) determinam as políticas alternativas a serem adotadas”. É essencial, para o sucesso do desenvolvimento da economia regional, qualificar de forma técnica e gerencial os agentes econômicos envolvidos. Trata-se da criação de vantagens competitivas através da capacitação e organização sócio-produtiva da região, considerado como fator endógeno de transformação socioeconômica.

Desenvolver sustentavelmente uma região pressupõe determinados fatores de competitividade. Conforme Haddad, dentre estes fatores (1999, pág. 10) pode-se destacar: “o aumento da autonomia local para tomada de decisões, a capacidade para reter e reinvestir excedente econômico gerado pelo processo de crescimento local, o crescente processo de inclusão social e a permanente conservação e preservação do ecossistema local”.

É fundamental a compreensão de que o processo de capacitação é capaz de transcender os aspectos econômicos materializados pela desejável melhoria dos índices técnicos de eficiência econômica; pois não há garantia que a expansão do ciclo econômico implique em melhores condições de vida da população. No Brasil este fato é observado nos períodos de maior crescimento econômico, os quais não impediram que a nação brasileira se torna-se um dos lugares do mundo de maiores índice de desigualdade social.

A especificidade da Chapada dos Veadeiros, exige que aspectos sociais e ambientais sejam tratados de forma integrada à dimensão produtiva; pois a integração produtiva interregional é fator atenuante do processo de exclusão social e, no que diz respeito à questão ambiental, não se pode deixar de considerar o zoneamento ecológico econômico - ZEE, no qual são apontadas, por força de lei, as atividades econômicas permitidas, toleradas e proibidas, dada a constituição da Reserva da Biosfera do Cerrado - GOYAZ FASE II. 


\section{C.5.2) Indicadores Sociais}

A microrregião da Chapada apresenta um quadro social caracterizado pela deficiência em setores estratégicos como educação e saneamento básico. A falta de informações e/ou esclarecimentos à população, aliada às condições de habitação, são fatores propagadores de doenças como dengue, doença de chagas, diarréia, contaminações por verminose e a leishmaniose.

Segundo informações da Superintendência de Ações Básicas da Saúde - Secretaria Estadual de Saúde de Goiás - tais enfermidades ocorrem com freqüência, elevando o número de óbitos e provocando o agravamento da saúde pública na Chapada. Fato que poderia ser prevenido ou controlado através de hábitos simples de higiene, cobertura vacinal e tratamento adequado de esgoto. Este é um fator a ser percebido como de repulsão turística, se não for tratado de forma adequada . Nenhuma pessoa pretende sair de seu local de origem para contrair doenças típicas de localidades com precárias condições sanitárias.

Conforme os dados da Tabela 13, a região possui sete hospitais e 219 leitos. A microrregião da Chapada contava no ano de 2002, com 26 médicos ${ }^{9}$ para atender uma população de aproximadamente 56.011 habitantes. De acordo com o parâmetro definido pela Organização Mundial da Saúde - OMS, seria necessário um médico para cada mil habitantes. Isto significa que o número de médicos deveria ser aumentado em 115,40\% para atingir o que é preconizado pela referida instituição. No que diz respeito ao número de leitos, a microrregião necessita de um incremento de apenas 6 leitos (aumento de 2,74\%) para atingir o total de 225 leitos e superar a defasagem de 5,04 leitos, situando-se dentro do parâmetro aceitável pela OMS de 4 leitos para cada mil habitantes.

O saneamento básico da microrregião da Chapada é outro aspecto que apresenta deficiência. O número de domicílios com tratamento adequado de esgoto, compreendendo banheiro ou sanitário, é de apenas 125 para todos os oito municípios da microrregião (Tabela 14). Além da pequena quantidade de domicílios atendidos por instalações adequadas de esgoto.

\footnotetext{
${ }^{9}$ Plano Municipal de Desenvolvimento Rural Sustentável - Pesquisa realizada pela Agência Goiana de Desenvolvimento Rural e Fundiário (2002).
} 
TABELA 13 - HOSPITAIS E POSTOS DE ATENDIMENTO MÉDICO

\begin{tabular}{|c|c|c|c|c|c|c|c|}
\hline Municípios & População & Hospitais & $\begin{array}{c}\mathbf{N}^{\circ} \\
\text { Leitos }\end{array}$ & $\begin{array}{c}\mathrm{N}^{\circ} \text { de } \\
\text { Médicos }\end{array}$ & $\begin{array}{l}\text { População } \\
\text { por Médico }^{1}\end{array}$ & $\begin{array}{c}\text { Excedente }^{2} \\
\text { populacional } \\
\text { p/ Médico }\end{array}$ & $\begin{array}{l}\text { Defasagem } \\
N^{\circ} \text { de Leitos }\end{array}$ \\
\hline Alto Paraíso de Goiás & 6.182 & 1 & 40 & 6 & 1030 & 30 & $-15,27$ \\
\hline Campos Belos & 17.047 & 2 & 123 & 10 & 1705 & 705 & $-54,81$ \\
\hline Cavalcante & 9.150 & 1 & 12 & - & - & - & 24,60 \\
\hline Colinas do Sul & 3.702 & 1 & 9 & - & - & - & 5,81 \\
\hline Monte Alegre de Goiás & 6.892 & 1 & 18 & 2 & 3446 & 2.446 & 9,57 \\
\hline Nova Roma & 3.717 & 0 & 0 & 1 & 3717 & 2.717 & 14,87 \\
\hline São João d' Aliança & 6.736 & 1 & 17 & 6 & 1.123 & 123 & 9,94 \\
\hline Teresina de Goiás & 2.585 & 0 & 0 & 1 & 2585 & 1.585 & 10,34 \\
\hline Total & 56.011 & $\overline{7}$ & 219 & 26 & 2.154 & 1.154 & $\overline{5,04}$ \\
\hline \multicolumn{8}{|c|}{ Fonte: Fundação Instituto Brasileiro de Geografia e Estatística - Censo 2000} \\
\hline \multicolumn{8}{|c|}{1 - Dados provenientes da Agência Goiana de Desenvolvimento Rural e Fundiário } \\
\hline \multicolumn{8}{|c|}{2 - O parâmetro adotado pela Organização Mundial da Saúde - OMS, é de 1.000 habitantes por médico. } \\
\hline \multicolumn{8}{|c|}{3 - Considerou-se como parâmetro a necessidade de 4 leitos por grupo de mil habitantes. } \\
\hline
\end{tabular}

O município de São João d' Aliança possui um hospital próximo da rodovia GO 118 com dezessete leitos. Contava no ano de 2002, com 6 médicos ${ }^{10}$ para atender uma população de aproximadamente 6.736 habitantes. Segundo a OMS, o número de médicos deve ser aumentado em 12,26\% - que é preconizado pela referida instituição. No que diz respeito ao número de leitos, o município necessita de um incremento de 10 leitos (aumento de 58,82\%) para atingir o total de 27 leitos e superar a defasagem. De acordo com a tabela 15, o município apresenta percentual de 1,70\% de instalações adequadas de esgoto, possuindo somente nove domicílios com banheiro ou sanitário (Tabela 14), apresentando, assim uma defasagem de 98,30\%.

${ }^{10}$ Plano Municipal de Desenvolvimento Rural Sustentável - Pesquisa realizada pela Agência Goiana de Desenvolvimento Rural e Fundiário (2002). 

TABELA 14 - SERVIÇOS SOCIAIS BÁSICOS

\begin{tabular}{|c|c|c|c|c|c|c|c|c|}
\hline Municípios & $\begin{array}{l}\text { No Domicílios } \\
\text { com } \\
\text { Esgotamento }^{\mathrm{a}} \\
\text { Adequado }\end{array}$ & $\begin{array}{c}\mathrm{N}^{\mathrm{o}} \\
\text { Domicílios } \\
\text { com Lixo } \\
\text { Coletado }\end{array}$ & $\begin{array}{l}\text { Abasteci- } \\
\text { mento } \\
\text { Água por } \\
\text { Domicílio }\end{array}$ & $\begin{array}{l}\text { Escola } \\
\text { Ensino } \\
\text { Médio }\end{array}$ & Alunos & $\begin{array}{l}\text { Escola } \\
\text { Ensino } \\
\text { Funda- } \\
\text { mental }\end{array}$ & Alunos & População \\
\hline Alto Paraiso de Goiás & 51 & 1.161 & 1.164 & 1 & 248 & 11 & 1.495 & 6.182 \\
\hline Campos Belos & 31 & 2.936 & 3.561 & 2 & 890 & 15 & 5.426 & 17.047 \\
\hline Cavalcante & 21 & 819 & $1.047 \mid$ & 1 & 83 & 63 & 2.884 & 9.150 \\
\hline Colinas do Sul & 3 & 577 & 656 & 1 & 111 & 13 & 1.059 & 3.702 \\
\hline Monte Alegre de Goiás & 8 & 558 & 896 & 1 & 269 & 36 & 2.047 & 6.892 \\
\hline Nova Roma & 2 & 302 & 641 & 1 & 132 & 17 & 1.226 & 3.717 \\
\hline São João D'Aliança & 9 & 1036 & 1.152 & 1 & 240 & 23 & 1.941 & 6.736 \\
\hline Teresina de Goiás & 0 & 426 & 426 & 1 & 74 & 5 & 780 & 2.585 \\
\hline Total Geral & 125 & 7.815 & 9.543 & 9 & 2.047 & 183 & 16.858 & 56.011 \\
\hline
\end{tabular}

Fonte: Fundação Instituto Brasileiro de Estatística e Geografia - FBGE 2000

a - Banheiro ou sanitário 
TABELA 15 - PERFIL DA MICRORREGIÃO CHAPADA DOS VEADEIROS - INDICADORES SOCIAIS (1991 - 2001)

\begin{tabular}{|c|c|c|c|c|c|c|c|c|c|c|c|c|}
\hline \multirow{3}{*}{ Municípios } & \multicolumn{6}{|c|}{ População } & \multirow{3}{*}{$\begin{array}{c}\text { Alfabeti- } \\
\text { zação }\end{array}$} & \multirow{3}{*}{\begin{tabular}{|c|} 
Alfabetizados \\
cl menos de 8 \\
anos de \\
estudo $^{b}$
\end{tabular}} & \multirow{3}{*}{\begin{tabular}{|c|} 
Crianças $^{c}$ \\
não \\
frequentam \\
escola
\end{tabular}} & \multirow{3}{*}{$\begin{array}{l}\text { Instalações } \\
\text { adequadas } \\
\text { de esgoto }\end{array}$} & \multirow{3}{*}{ I.D.H. ${ }^{d}$} & \multirow{3}{*}{$\begin{array}{c}\text { I.D.H. } \\
\text { Renda }^{\mathrm{d}}\end{array}$} \\
\hline & \multicolumn{2}{|c|}{ Total } & \multicolumn{2}{|c|}{ Urbana } & \multicolumn{2}{|c|}{ Rural } & & & & & & \\
\hline & 2000 & $2001^{a}$ & 2000 & $2001^{a}$ & 2000 & $2001^{a}$ & & & & & & \\
\hline Chapada & 56.011 & 56.915 & 34.339 & 35.021 & 21.672 & 21.894 & $78,64 \%$ & $86,56 \%$ & $32,51 \%$ & $10,28 \%$ & 0,557 & 0,509 \\
\hline Alto Paraíso de Goiás & 6.182 & 6.416 & 4.179 & 4.337 & 2.003 & 2.079 & $86,40 \%$ & $77,90 \%$ & $26,10 \%$ & $11,30 \%$ & 0,584 & 0,512 \\
\hline Campos Belos & 17.047 & 17.315 & 14.207 & 14.430 & 2.840 & 2.885 & $82,40 \%$ & $84,30 \%$ & $16,30 \%$ & - & 0,572 & - \\
\hline Cavalcante & 9.150 & 9.253 & 3.654 & 3.695 & 5.496 & 5.558 & $61,70 \%$ & $92,70 \%$ & $52,30 \%$ & $23,70 \%$ & 0,416 & 0,273 \\
\hline Colinas do Sul & 3.702 & 3.733 & 2.249 & 2.268 & 1.453 & 1.465 & $82,70 \%$ & $90,30 \%$ & $20,40 \%$ & $4,40 \%$ & 0,530 & 0,620 \\
\hline Monte Alegre de Goiás & 6.892 & 6.776 & 2.746 & 2.700 & 4.146 & 4.076 & $75,80 \%$ & $89,20 \%$ & $33,50 \%$ & - & 0,436 & 0,308 \\
\hline Nova Roma & 3.717 & 3.571 & 1.341 & 1.288 & 2.376 & 2.283 & $81,90 \%$ & $90,10 \%$ & $29,60 \%$ & - & 0,479 & 0,328 \\
\hline São João D`Aliança & 6.736 & 7.112 & 4.188 & 4.422 & 2.548 & 2.690 & $84,00 \%$ & $91,50 \%$ & $28,30 \%$ & $1,70 \%$ & 0,529 & 0,399 \\
\hline Teresina de Goiás & 2.585 & 2.739 & 1.775 & 1.881 & 810 & 858 & $74,20 \%$ & $76,50 \%$ & $53,60 \%$ & - & 0,569 & 0,506 \\
\hline
\end{tabular}

Fonte: Secretaria do Planejamento e Desenvolvimento do Estado de Goiás - Superintendência de Estatística, Pesquisa e Informação

Atlas de Desenvolvimento Humano no Brasil - 1991. Programa das Nações Unidas para o Desenvolvimento - PNUD, Instituto de Pesquisa Econômica Aplicada - IPEA, Fundação João Pinheiro,

Fundação Instituto Brasileiro de Geografia e Estatística - IBGE.

a - População estimada com base na participação percentual do ano anterior.

b - Porcentagem da população com 25 anos de idade e mais.

c - Crianças de 7 a 14 anos.

d - Dados referentes a 1991.

População da Chapada em $1991=49.723$ habitantes

Variação Populacional Região NE/GO 1991 - 2001 = 11,20\% no período

Taxa Equivalente Anual Variação Populaciopnal Região NE/GO = 1,07\% a.a.

IDH Estado de Goiás: 1991 = 0,722

IDH - Renda do Estado de Goiás: 1991 = 0,875 
Os indicadores sociais da área educacional (Tabela 15) revelam uma situação alarmante. Apesar de 78,64\% da população ser considerada alfabetizada, o que significa um percentual de analfabetos na ordem de 21,36\%; constata-se que da população alfabetizada, 86,56\% possuem menos de oito anos de estudo ${ }^{11}$.

Os dados referentes à educação infantil na região são assustadores, pois revelam que 32,51\% das crianças de 7 a 14 anos não freqüentam escola. Nos oito municípios da Chapada, mais de 15\% da população de crianças em idade escolar, não freqüentam escola. Chega-se ao absurdo de haver 53,60\% de crianças excluídas do processo de educação no Município de Teresina de Goiás. Os dados do corpo discente, do ensino fundamental e médio, revelam alto índice de reprovação e abandono. São João d' Aliança não é uma exceção a regra, mesmo com índices um pouco melhores do que os dos demais municípios.

A realidade social da localidade exposta nos indicadores econômicos e sociais apresentados ao longo deste trabalho pode ser sintetizada através do Índice de Desenvolvimento Humano - $\mathrm{IDH}^{12}$.

${ }^{11}$ Não é pretensão do presente trabalho discorrer sobre a qualidade da alfabetização na microrregião da Chapada dos Veadeiros. Porém, deve-se considerar a existência de pelo menos quatro níveis de escolaridade e suas respectivas durações:

a) Creche: é o primeiro nível da Educação Infantil; corresponde à faixa etária de 0 a 3 anos de idade e tem duração de quatro anos.

b) Pré-escola: é o segundo nível da Educação Infantil, e corresponde à faixa de 4 a 6 anos de idade; é neste nível que a criança é alfabetizada.

c) Ensino Fundamental: é o antigo “ $1^{\circ}$ grau”, abrange da $1^{\text {a }}$ à $8^{\mathrm{a}}$ série, com duração de oito anos; corresponde à faixa etária de 7 a 14 anos de idade.

d) Ensino Médio: é o antigo “ $2^{\circ}$ grau”, abrange da $1^{\text {a }}$ à $3^{\mathrm{a}}$ série, com duração de 3 anos; corresponde à faixa etária de 15 a 17 anos.

12 O Índice de Desenvolvimento Humano - IDH, consiste num indicador sintético que combina três componentes básicos do desenvolvimento humano:

a) LONGEVIDADE; que engloba, entre outras coisas, as condições de saúde da população; medida pela esperança de vida ao nascer;

b) EDUCAÇÃO; medida por uma combinação da taxa de alfabetização de adultos e a taxa combinada de matrícula nos níveis de ensino fundamental, médio e superior;

c) RENDA; medida pelo poder de compra da população, baseado no PIB per capita ajustado ao custo de vida local para torná-lo comparável entre países e regiões, através da metodologia conhecida como paridade do poder de compra (PPC)

A metodologia de cálculo do Índice de Desenvolvimento Humano - IDH envolve a transformação destas três dimensões em índices de longevidade, educação e renda, que variam entre 0 (pior) e 1 (melhor), e a combinação destes índices em um indicador síntese. Quanto mais próximo de 1 o valor deste indicador, maior será o nível de desenvolvimento humano do país ou região. Operacionalmente classifica-se como baixo, o IDH inferior a 0,501; médio, o IDH entre 0,500 e 0,801; e alto, o IDH acima de 0,800. 
O IDH dos municípios que compõem a região, para o ano de 1991, está apresentado na Tabela 15. Os dados revelam que o IDH de 37,5\% dos municípios situa-se abaixo de 0,500; caracterizando a insuficiência do desenvolvimento humano na microrregião. A título de comparação, o valor médio do IDH da região é de 0,51 (1991), aproxima-se ao IDH de países $^{13}$ como Iêmen e Bangladesh (IDH $\left.=0,48\right)$, países considerados efetivamente pobres; e situa-se muito abaixo do valor do IDH do Estado de Goiás, na ordem de 0,72 (1991). Chama a atenção o indicador IDH - RENDA dos municípios da região; pois reflete as condições e possibilidades na obtenção de renda. Como a região produz, basicamente, gêneros de subsistência, cuja escala de produção não é capaz de dinamizar a economia local ou, quando muito, gerar algum rendimento gera-se uma perspectiva que é ratificada através do IDH - RENDA dos municípios, pois; 62,5\% dos municípios apresentam valores de IDH - RENDA inferiores a 0,500; sendo a média da região em 1991 igual a 0,421 (dados da Tabela 16).

Para o início de 2000, no momento em que há a divulgação do Relatório de Desenvolvimento Humano - RDH de 2002; constata-se uma melhora significativa para o Brasil $^{14}$, passando de $75^{\circ}$ colocação (IDH $\left.=0,753\right)$ para $73^{\circ}$ colocação (IDH $=0,757$ ) no ranking de países do referido relatório.

O Estado de Goiás, a exemplo do que ocorreu no país, apresentou melhoria em seu Índice de Desenvolvimento Humano - IDH; passando da 9a posição em 1991 (IDH = 0,722) para a $7^{\mathrm{a}}$ posição em $2000(\mathrm{IDH}=0,770)$.

No que diz respeito à microrregião da Chapada, o IDH saltou de 0,514 em 1991, para 0,677 em 2000 (dados da Tabela 16). Nota-se, ainda, que o IDH-M E (educação) foi o que mais contribuiu (51,23\%) para a evolução do IDH; que o IDH M R (renda) participou de modo contundente (38,69\%) para que o IDH chegasse ao patamar de 0,677 e que o IDH-M L (longevidade), apesar da menor contribuição (10,21\%), apresentou expressivo crescimento. Portanto, em termos absolutos, é incontestável a melhora do IDH na Chapada dos Veadeiros como um todo.

\footnotetext{
${ }^{13}$ Relatório de Desenvolvimento Humano Internacional, 1991.

14 A evolução do IDH no Brasil foi de tal ordem que o Programa das Nações Unidas para o Desenvolvimento concedeu um prêmio ao Presidente da Republica Federativa do Brasil., Fernando Henrique Cardoso; sendo o primeiro vencedor do prêmio Mahbub Ul Haq, assim chamado para homenagear o economista paquistanês que foi pioneiro no enfoque do desenvolvimento humano e que instituiu o Relatório Global sobre Desenvolvimento Humano.
} 
Porém, ao analisar a microrregião da Chapada e compará-la às outras microrregiões de Goiás constata-se que, apesar dos avanços no IDH-M, a localidade ainda apresenta um forte desequilíbrio. Tal perspectiva é demonstrável ao estabelecer-se parâmetros microrregionais utilizando-se o instrumental estatístico. Não se trata do abandono dos limites baixo, médio e alto do IDH; mas do estabelecimento de um critério, com base no índice proposto pelo Programa das Nações Unidas para o Desenvolvimento - PNUD, ou seja, o próprio IDH, capaz de mensurar o nível de desigualdade de uma região. Especificamente, a análise da microrregião da Chapada dos Veadeiros permite uma avaliação cujo lastro materializa-se no IDH dos municípios pertencentes a esta microrregião do Estado de Goiás.

A metodologia proposta consiste em calcular o índice médio de desenvolvimento humano de cada microrregião, baseado no IDH de cada município, estabelecendo-se uma variância em torno da média (desvio padrão), limites inferiores e superiores que servirão de parâmetros para situar a microrregião e classificá-la abaixo, dentro ou superior à margem que definiria a média das microrregiões em análise.

Conforme dados da Tabela 17 a microrregião da Chapada dos Veadeiros, apresenta um dos menores índices médios de Desenvolvimento Humano do Estado de Goiás: 0,678. Os dados evidenciam que a Chapada dos Veadeiros possui Índices de Desenvolvimento Humano que se situam abaixo da margem que caracteriza a média dos Índices de Desenvolvimento para as demais microrregiões do Estado. Apesar dos valores da localidade se situarem em um patamar que classificaria os respectivos municípios como de IDH médio, é notório que a necessidade de ações que permitam equalizar seu nível de desenvolvimento com os de municípios de outras microrregiões do Estado.

As políticas e programas de incentivo à geração de emprego e renda na região, podem ser consideradas insuficientes. Apenas 50\% dos municípios da região apresentam atrativos de atividades econômicas; 37,5\% dos municípios possuem programas de geração de emprego e renda; e, apesar de 100\% dos municípios receberem auxílio do Programa Comunidade Solidária (Tabela 18), tais iniciativas não surtiram o resultado desejável, tanto quantitativa quanto qualitativamente, ou seja; não foram capazes de impulsionar o desenvolvimento sustentável da região, dado o nível de carências e demandas sociais na região. 


\section{C.5.3) Organização Social}

Apesar da existência de inúmeras associações, conselhos municipais e sindicatos na microrregião da Chapada dos Veadeiros; não significa que estas organizações sociais tenham bases estruturais sólidas e que haja uma participação efetiva de seus associados. Os municípios de São João d’Aliança, Alto Paraíso e de Cavalcante apresentam os maiores números de associações da microrregião da Chapada dos Veadeiros, porém as ações e propostas promovidas não foram ainda suficientes para impulsionar o desenvolvimento local.

É necessário promover uma reavaliação do associativismo, considerando seus desafios, especificidades e priorizando a capacitação de lideranças locais, internalizando a concepção de que uma estrutura organizacional eficiente é uma das alternativas para superar-se os obstáculos ao desenvolvimento tanto no âmbito local quanto no âmbito regional. São João d' Aliança começa se despontar no quesito associativismo na região. Os Fóruns de desenvolvimento originados com o Programa Comunidade Ativa do Governo Federal foram bem sucedidos no município. O referido Programa possuía o objetivo de implantar a metodologia DLIS (Desenvolvimento Local Integrado e Sustentável), no qual a comunidade é sensibilizada de sua condição de agente principal de desenvolvimento do local onde reside.

O atual estágio de mobilização social encontra-se bem desenvolvido, com a comunidade criando uma agência de desenvolvimento chamada de Casa da Capetinga, onde também se encontra uma agência de ecoturismo chamada giro, um espaço para a realização de atividades culturais. O envolvimento de diversos segmentos da sociedade, como líderes de assentamentos, funcionários públicos, agentes de turismo, profissionais liberais, líderes religiosos, entre outros, sem discriminação de raça, nacionalidade, política e religião tem demonstrado um novo grau de maturidade de um grupo consciente de sua função social. Uma escola de turismo e educação ambiental foi criada como um novo modelo pedagógico no local. Seu intuito é divulgar conhecimentos técnicos - como o uso de GPS, a elaboração de projetos turísticos, entre outros - que permitam o aprendizado relacionado as realidades das atividades que possam ser realizadas na localidade. 
TABELA 16 - ÍNDICE DE DESENVOLVIMENTO HUMANO: EVOLUÇÃO CHAPADA DOS VEADEIROS (1991-2000)

\begin{tabular}{|c|c|c|c|c|c|c|c|c|c|c|c|c|}
\hline \multirow{2}{*}{ Municípios } & \multicolumn{3}{|c|}{ IDHM } & \multicolumn{3}{|c|}{$\overline{I D H M L}$} & \multicolumn{3}{|c|}{ IDHME } & \multicolumn{3}{|c|}{ IDHMR } \\
\hline & 1991 & 2000 & Cresc. \% & 1991 & 2000 & Cresc. \% & 1991 & 2000 & Cresc. \% & 1991 & 2000 & Cresc. \% \\
\hline Alto Paraíso de Goiás & 0,584 & 0,738 & 26,37 & 0,642 & 0,716 & 11,60 & 0,597 & 0,838 & 40,39 & 0,512 & 0,660 & $\overline{28,84}$ \\
\hline Campos Belos & 0,572 & 0,708 & 23,69 & 0,622 & 0,716 & 15,19 & 0,538 & 0,800 & 48,61 & - & 0,607 & - \\
\hline Cavalcante & 0,416 & 0,609 & 46,28 & 0,622 & 0,696 & 11,95 & 0,352 & 0,603 & 71,22 & 0,273 & 0,527 & 92,90 \\
\hline Colinas do Sul & 0,530 & 0,671 & 26,61 & 0,622 & 0,639 & 2,78 & 0,533 & 0,794 & 49,01 & 0,620 & 0,580 & $-6,52$ \\
\hline Monte Alegre de Goiás & 0,436 & 0,626 & 43,50 & 0,596 & 0,621 & 4,25 & 0,403 & 0,729 & 80,96 & 0,308 & 0,526 & 70,90 \\
\hline Nova Roma & 0,479 & 0,679 & 41,66 & 0,622 & 0,696 & 11,95 & 0,486 & 0,792 & 62,90 & 0,328 & 0,548 & 66,97 \\
\hline São João d' Aliança & 0,529 & 0,719 & 35,84 & 0,660 & 0,716 & 8,55 & 0,528 & 0,788 & 49,25 & 0,399 & 0,651 & 63,23 \\
\hline Teresina de Goiás & 0,569 & 0,672 & 18,05 & 0,622 & 0,716 & 15,19 & 0,577 & 0,727 & 25,98 & 0,506 & 0,572 & 13,00 \\
\hline Evolução média & $\overline{0,514}$ & $\overline{00,677}$ & 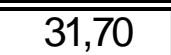 & $\overline{0,626}$ & 0,690 & $\overline{10,21}$ & $\overline{0,502}$ & 0,759 & $\overline{51,23}$ & $\overline{0,421}$ & 0,584 & $\overline{38,69}$ \\
\hline
\end{tabular}


TABELA 17 - DESEQUILÍBRIO REGIONAL: MICRORREGIÕES DO ESTADO DE GOIÁS (IDH 2000)

\begin{tabular}{l|c}
\hline \multicolumn{1}{c|}{ Microrregiões } & Média IDH (2000) \\
\hline Catalão & 0,777 \\
Pires do Rio & 0,775 \\
Meia Ponte & 0,77 \\
Sudoeste de Goiás & 0,759 \\
Quirinópolis & 0,753 \\
Vale do Rio dos Bois & 0,744 \\
Aragarças & 0,737 \\
Anápolis & 0,736 \\
Ceres & 0,730 \\
Porangatu & 0,730 \\
Rio Vermelho & 0,720 \\
Entorno de Brasília & 0,717 \\
São Miguel do Araguaia & 0,711 \\
Chapada dos Veadeiros & 0,678 \\
Vão do Paranã & 0,656 \\
\hline \hline Média Microrregiões - Goiás & 0,733 \\
Desvio Padrão & 0,034 \\
Limite Inferior & 0,699 \\
Limite Superior & 0,767 \\
IDH - Estado de Goiás & 0,770 \\
\hline
\end{tabular}

Fonte: Atlas de Desenvolvimento Humano no Brasil - 2000

TABELA 18 - POLÍTICAS E PROGRAMAS DE GERAÇÃo DE EMPREGO, PRODUÇÃO E RENDA

\begin{tabular}{l|c|c|c|c|c|c}
\hline \multicolumn{1}{c|}{ Municípios } & $\begin{array}{c}\text { Atração de } \\
\text { Atividades } \\
\text { Econômicas }\end{array}$ & $\begin{array}{c}\text { Doação de } \\
\text { Terras }\end{array}$ & $\begin{array}{c}\text { Outros } \\
\text { Incentivos }\end{array}$ & $\begin{array}{c}\text { Recebimento de } \\
\text { Auxílio do } \\
\text { Programa } \\
\text { Comunidade } \\
\text { Solidária }\end{array}$ & $\begin{array}{c}\text { Programas de } \\
\text { Geração de } \\
\text { Trabalho e } \\
\text { Renda }\end{array}$ & $\begin{array}{c}\text { Programa de } \\
\text { Capacitação } \\
\text { Profissional }\end{array}$ \\
\hline Alto Paraíso de Goiás & não & - & - & $\operatorname{sim}$ & $\operatorname{sim}$ & $\operatorname{sim}$ \\
Campos Belos & $\operatorname{sim}$ & não & não & $\operatorname{sim}$ & não & não \\
Cavalcante & não & - & - & $\operatorname{sim}$ & $\operatorname{sim}$ & não \\
Colinas do Sul & $\operatorname{sim}$ & $\operatorname{sim}$ & $\operatorname{sim}$ & $\operatorname{sim}$ & não & sim \\
Monte Alegre de Goiás & $\operatorname{sim}$ & não & $\operatorname{sim}$ & $\operatorname{sim}$ & não & não \\
Nova Roma & $\operatorname{sim}$ & $\operatorname{sim}$ & $\operatorname{sim}$ & $\operatorname{sim}$ & não \\
São João d'Aliança & não & - & - & $\operatorname{sim}$ & sim & nãm \\
Teresina de Goiás & não & - & - & $\operatorname{sim}$ & não \\
\hline
\end{tabular}

Fonte: Sistema Nacional de Indicadores Urbanos 


\section{C.5.4) Estrutura Fundiária}

Para mostrar a realidade regional no quesito situação fundiária da Chapada, recorreuse ao Sistema Nacional de Cadastro Rural do INCRA. Na Tabela 19, o conjunto dos oito municípios que compõe esta microrregião totaliza 2.894 imóveis rurais que somam 1.763.893,40 hectares. Vale ressaltar que as tabelas da microrregião estão consignando imóveis rurais cadastrados no INCRA. Para todas as situações registradas, é possível a existência de outros imóveis que não tenham sido cadastrados.

TABELA 19 - DISTRIBUIÇÃO DE IMÓVEIS RURAIS: CHAPADA DOS VEADEIROS

\begin{tabular}{|c|c|c|c|}
\hline Classes de Área em Hectares & $\begin{array}{l}\text { Total de } \\
\text { Imóveis }\end{array}$ & $\begin{array}{c}\text { Total da Área em } \\
\text { Hectares }\end{array}$ & $\begin{array}{l}\text { Média em } \\
\text { Hectares }\end{array}$ \\
\hline Até 5 & 48 & 193,80 & 4,04 \\
\hline Mais de 5 até 10 & 41 & 363,70 & 8,87 \\
\hline Mais de 10 até 50 & 556 & $18.943,70$ & 34,07 \\
\hline Mais de 50 até 100 & 473 & $35.454,30$ & 74,96 \\
\hline Mais de 100 até 500 & 987 & $248.357,40$ & 251,63 \\
\hline Mais de 500 até 1.000 & 322 & $236.680,30$ & 735,03 \\
\hline Mais de 1.000 até 5.000 & 425 & $934.250,70$ & $2.198,24$ \\
\hline Mais de 5.000 até 10.000 & 42 & $289.649,50$ & $6.896,42$ \\
\hline Mais de 10.000 até 50.000 & - & - & . \\
\hline Mais de 50.000 até 100.000 & - & - & - \\
\hline Mais de 100.000 & - & - & - \\
\hline Total & 2.894 & $1.763 .893,40$ & 609,50 \\
\hline
\end{tabular}

FONTE: Sistema Nacional de Cadastro Rural - INCRA, posição de 03/05/2001

Conforme estabelece a Lei 8.629/1993, os imóveis rurais no Brasil estão classificados em pequena, média e grande propriedades, cujo indicador de classificação é o módulo fiscal, que varia de município para município. A pequena propriedade é toda aquela que possui até quatro módulos fiscais. Área acima de quatro e até quinze módulos fiscais, classifica o imóvel rural como sendo de média propriedade. Qualquer imóvel rural acima de quinze módulos fiscais é classificado como grande propriedade. Estas classificações foram estabelecidas a partir da promulgação da Constituição Federal de 1998, substituindo as figuras do latifúndio por dimensão e latifúndio por exploração, preconizadas no Estatuto da Terra (Lei 4.504/1964).

No caso da microrregião da Chapada, o módulo fiscal que aparece com maior freqüência é o de 70 hectares, havendo apenas dois municípios em que são registrados o 
módulo fiscal de 80 hectares - Campos Belos e Monte Alegre de Goiás (Tabela 20). O município de São João d’Aliança apresenta módulo fiscal de 70 hectares.

A Tabela 20 mostra que o INCRA (Instituto Nacional de Cooperativismo e Reforma Agrária) instalou doze projetos de assentamento em sete municípios da Chapada através do Programa de Reforma Agrária, contemplando 597 famílias de trabalhadores rurais, o que representa a mesma quantidade de propriedades inseridas no contexto da agricultura familiar. O município de São João d’Aliança é o que apresenta o maior número de projetos e de famílias assentadas, sendo seis projetos e duzentos e oitenta e cinco famílias assentadas no ano de 1999.

TABELA 20 - ASSENTAMENTOS E FAMÍLIAS ASSENTADAS: INCRA (1999)

\begin{tabular}{l|r|r}
\hline \multicolumn{1}{c|}{ Municípios } & Número de Projetos & \multicolumn{2}{c}{$\begin{array}{c}\text { Número de Famílias } \\
\text { Assentadas }\end{array}$} \\
\hline Alto Paraíso de Goiás & 1 & 64 \\
Cavalcante & 1 & 121 \\
Colinas do Sul & 1 & 0 \\
Monte Alegre de Goiás & 1 & 76 \\
Nova Roma & 1 & 0 \\
São João d'Aliança & 6 & 285 \\
Teresina de Goiás & 1 & 51 \\
\hline \hline Total & $\mathbf{1 2}$ & $\mathbf{5 9 7}$ \\
\hline Fonte: Sistema Nacional de Indicadores Urbanos 2002 &
\end{tabular}

Fonte: Sistema Nacional de Indicadores Urbanos 2002

Finalmente, a Tabela 22 possibilita a visualização de como está distribuída a área total da microrregião Chapada dos Veadeiros, que é de 2.137.700 hectares. Deste total, 237.000 hectares formam o Sítio Histórico e Patrimônio Cultural Kalunga - comunidade com cerca de 4.000 remanescentes de quilombos - encravado na junção de três municípios: Cavalcante, Monte Alegre de Goiás e Teresina de Goiás, com mais de dois séculos de existência. Há ainda a reserva indígena dos Avá-Canoeiros, em processo de extinção com apenas seis membros em 19.148 hectares. Cerca de 1.086.217 de hectares correspondem à área de preservação ambiental da região, o que corresponde a, aproximadamente, 50,8\% da microrregião da Chapada, ou melhor, mais da metade de sua área. Desta área, é de 5,25\% a participação do município de São João da Aliança em áreas de preservação ambiental, com 57.020 hectares. 
TABELA 21 - INDICADORES CADASTRAIS DE IMÓVEIS RURAIS DA CHAPADA DOS VEADEIROS (1997)

\begin{tabular}{|c|c|c|c|c|c|c|c|c|c|c|}
\hline \multicolumn{2}{|c|}{ Unidade Geográfica } & \multirow{2}{*}{ ZP } & \multirow{2}{*}{$\begin{array}{l}\text { Módulo } \\
\text { Fiscal (ha) }\end{array}$} & \multirow{2}{*}{$\begin{array}{l}\text { ZTM IE } \\
50 / 97\end{array}$} & \multirow{2}{*}{ FMP (ha) } & \multirow{2}{*}{$\begin{array}{l}\text { LIM. EST. } \\
\text { (ha) }\end{array}$} & \multicolumn{2}{|c|}{ Situação Cadastral } & \multirow{2}{*}{$\begin{array}{c}\text { Super. } \\
\text { Territ. }\left(\mathrm{Km}^{2}\right)\end{array}$} & \multirow{2}{*}{$\begin{array}{l}\text { Áreas } \\
\text { Especiais }\end{array}$} \\
\hline Municípios & MRG & & & & & & Imóveis & Área (ha) & & \\
\hline Alto Paraíso de Goiás & 005 & 4 & 70 & B3-6 & 4 & 90 & 324 & $177.858,3$ & $2.603,4$ & $\mathrm{P}$ \\
\hline Campos Belos & 005 & 4 & 80 & B3-6 & 4 & 90 & 169 & $58.995,2$ & 785,8 & $A$ \\
\hline Cavalcante & 005 & 4 & 70 & B3-6 & 4 & 90 & 386 & $428.702,7$ & $6.979,5$ & $\mathrm{P}$ \\
\hline Colinas do Sul & 005 & 4 & 70 & B3-6 & 4 & 90 & 228 & $137.656,6$ & $1.714,5$ & \\
\hline Monte Alegre de Goiás & 005 & 4 & 80 & B3-6 & 4 & 90 & 628 & $217.537,9$ & $3.131,5$ & $P$ \\
\hline Nova Roma & 005 & 4 & 70 & B3-6 & 4 & 90 & 322 & $274.671,4$ & $2.143,9$ & \\
\hline São João d'Aliança & 005 & 4 & 70 & B3-6 & 4 & 90 & 428 & $299.170,0$ & $3.339,5$ & $\mathbf{P}$ \\
\hline Teresina de Goiás & 005 & 4 & 70 & B3-6 & 4 & 90 & 48 & $35.885,8$ & 777,5 & $\mathrm{P}$ \\
\hline
\end{tabular}

FONTE: Sistema Nacional de Cadastro Rural - Índices Básicos de 1997 
TABELA 22 - DISTRIBUIÇÃO DA MALHA FUNDIÁRIA DA CHAPADA DOS VEADEIROS

\begin{tabular}{l|r|r|r|r|r}
\hline \multicolumn{1}{c|}{ Municípios } & $\begin{array}{c}\text { Área } \\
\text { Município }\end{array}$ & $\begin{array}{c}\text { Área Kalunga } \\
\text { I Reserva } \\
\text { Indígena }\end{array}$ & $\begin{array}{c}\text { Área } \\
\text { Ambiental }\end{array}$ & $\begin{array}{c}\text { Área } \\
\text { Titulada }\end{array}$ & $\begin{array}{c}\text { Área cl } \\
\text { possibilidade } \\
\text { de Titulação }\end{array}$ \\
\hline Alto Paraíso de Goiás & 259.400 & - & 246.652 & 27.683 & 157.970 \\
\hline Campos Belos & 78.300 & - & - & 8.066 & 70.234 \\
\hline Cavalcante & 695.400 & 153.248 & 427.349 & 212.572 & 261.299 \\
\hline Colinas do Sul & 170.800 & 19.148 & 134.496 & 4.743 & 146.909 \\
\hline Monte Alegre de Goiás & 312.000 & 42.546 & - & 12.844 & 256.609 \\
\hline Nova Roma & 213.600 & - & 186.400 & 53.708 & 159.892 \\
\hline São João D' Aliança & $\mathbf{3 3 2 . 7 0 0}$ & - & $\mathbf{5 7 . 0 2 0}$ & $\mathbf{9 0 . 5 7 1}$ & $\mathbf{2 4 0 . 8 1 3}$ \\
\hline Teresina de Goiás & 75.500 & 41.205 & 34.300 & 2.036 & 26.500 \\
\hline Total & $\mathbf{2 . 1 3 7 . 7 0 0}$ & $\mathbf{2 5 6 . 1 4 7}$ & $\mathbf{1 . 0 8 6 . 2 1 7}$ & $\mathbf{4 1 2 . 2 2 3}$ & $\mathbf{1 . 3 2 0 . 2 2 6}$ \\
\hline
\end{tabular}

FONTE: Agência Goiana de Desenvolvimento Rural e Fundiário.

Obs.: 1) Todas as áreas estão expressas em hectare (ha);

2) A área a ser titulada representa $76,51 \%$ do total dos municípios subtraindo a área já titulada, as áreas ambientais restritas, áreas dos Kalungas e as áreas indígenas,

3) As áreas ambientais restritas estão representadas pelo Parque Nacional Chapada dos Veadeiros (Alto Paraíso de Goiás, Cavalcante, Nova Roma, São João D' Aliança e Teresina de Goiás), Distrito de São Jorge (Alto Paraíso), Parque Municipal Abílio Herculano Szervinsk (Alto Paraíso), Parque Municipal Lavapés (Cavalcante) As áreas com menores restrições estão representadas pelas APAS (Àreas de Proteção Ambiental), de Pouso Alto (Alto Paraíso de Goiás, Cavalcante, Nova Roma, Teresina de Goiás, São João D' Aliança e Colinas do Sul), As áreas de reservas especiais são representadas pelo Sítio Histórico Patrimônio Cultural Kalunga (Cavalcante, Teresina de Goiás e Monte Alegre de Goiás) e a Reserva Indígena Avá-canoeiro (Colinas do Sul).

4) O cálculo das áreas ambientais por município foram feitos com base no mapa das unidades de conservação do Estado de Goiás, fornecido pela Agência Ambiental do Estado.

TABELA 23 - ESTRUTURA FUNDIÁRIA - UTILIZAÇÃO DOS SOLOS (1996)

\begin{tabular}{l|r|r|r|r|r}
\hline \multicolumn{1}{c|}{ Municípios } & \multicolumn{1}{c|}{$\begin{array}{c}\text { Número de } \\
\text { Estabelecimentos }\end{array}$} & $\begin{array}{c}\text { Área Total } \\
\text { (ha) }\end{array}$ & $\begin{array}{c}\text { Pastagens } \\
\text { (ha) }\end{array}$ & \multicolumn{1}{c}{$\begin{array}{c}\text { Lavouras } \\
\text { (ha) }\end{array}$} & \multicolumn{1}{c}{$\begin{array}{c}\text { Matas } \\
\text { (ha) }\end{array}$} \\
\hline ESTADO DE GOIÁS & $\mathbf{1 1 1 . 6 9 1}$ & $\mathbf{2 5 . 3 8 7 . 7 1 8}$ & $\mathbf{1 9 . 3 2 8 . 1 3 1}$ & $\mathbf{2 . 2 2 2 . 3 9 6}$ & $\mathbf{3 . 8 3 7 . 1 9 1}$ \\
005 - Chapada dos Veadeiros & $\mathbf{2 . 8 5 9}$ & $\mathbf{9 8 0 . 6 0 4}$ & $\mathbf{7 5 6 . 8 8 4}$ & $\mathbf{3 6 . 3 8 3}$ & $\mathbf{1 8 7 . 3 3 7}$ \\
Alto Paraiso de Goiás & 239 & 80.913 & 59.821 & 3.339 & 17.753 \\
Campos Belos & 197 & 46.462 & 34.497 & 10.802 & 1.163 \\
Cavalcante & 705 & 231.482 & 198.899 & 2.299 & 30.284 \\
Colinas do Sul & 220 & 74.195 & 61.781 & 1.748 & 10.666 \\
Monte Alegre de Goiás & 444 & 152.435 & 95.707 & 2.940 & 53.788 \\
Nova Roma & 438 & 112.349 & 89.659 & 2.454 & 20.236 \\
São João D'Aliança & 466 & 222.575 & 159.669 & 12.547 & 50.359 \\
Teresina de Goiás & 150 & 60.193 & 56.851 & 254 & 3.088 \\
& & & & & \\
\hline
\end{tabular}

FONTE: IBGE - Censo Agropecuário, 1995/96. 


\section{C.6) Infra-estrutura}

O setor de infra-estrutura tem papel fundamental para o desenvolvimento turístico e geral de uma região. A Chapada dos Veadeiros, no Estado de Goiás, não é diferente. Uma melhor infra-estrutura permite ganho de competitividade das unidades produtivas locais, pois reduz os preços de frete das mercadorias, o que reflete no custo final dos produtos .

Além disso, permite o acesso aos serviços turísticos de uma localidade, melhorando o desempenho da economia regional como um todo, facilitando o acesso do turista à região, resultando na possibilidade de aumento da oferta do emprego e de obtenção de renda pela população local.

Em contrapartida, as condições de acesso à localidade para o turista também podem melhorar as condições dos setores de apoio ao turismo local, de forma a alavancar atividades como o comércio, a produção do artesanato, do extrativismo e da agropecuária. Isto é motivado pela possibilidade de dinamização da economia local com a queda dos custos de transporte e com uma logística de transporte mais eficaz, proporcionando o apoio necessário para as atividades econômicas principais.

A redução dos preços dos produtos regionais é alcançada com a melhoria da infraestrutura local e regional, oportunizando aos produtores locais ofertarem seus produtos aos grandes centros consumidores, especialmente aos grandes mercados consumidores de Brasília e de Goiânia, além de permitir o aumento do fluxo turístico destes grandes centros para a região da Chapada dos Veadeiros .

A obtenção de melhores condições de hospedagem serão permitidas com a oferta de energia, água tratada, esgoto e serviços de telefonia. A melhoria das estradas e a pavimentação de rodovias podem permitir o acesso facilitado à região, caracterizada por belezas naturais únicas.

Aliado ao envolvimento da sociedade, a formação e incremento do capital humano seriam capazes de levar à região, o almejado desenvolvimento sustentável. Todos estes itens são necessários para que se possa implementar um plano de ecoturismo eficaz e coerente com as realidades locais do município de São João d’Aliança. 


\section{C.6.1) Estradas}

A região do nordeste goiano conta com uma malha viária que totaliza, aproximadamente, $480 \mathrm{~km}$ de estradas estaduais asfaltadas que interligam os seus municípios e dão acesso aos Estados da Bahia e do Tocantins.

O município de São João d'Aliança é cortado por um importante eixo de integração regional. Trata-se da rodovia GO-118. No entanto, esta estrada não possui uma interconexão com outra relevante rodovia da região, a federal BR-020, outra via de acesso à região do nordeste goiano, com $130 \mathrm{~km}$ de estrada asfaltada. A interligação entre ambas integraria a única opção de transporte desta região de forma adequada, permitindo o aumento do fluxo de turistas dentro da própria região. Este é um dos fatores que impede uma maior integração regional, gerando uma ampla dependência de São João d' Aliança e de toda a região do nordeste goiano em relação ao conglomerado urbano da capital federal, Brasília- DF.

Enquanto a estrada estadual GO-118 interliga os municípios da microrregião da Chapada dos Veadeiros, localizados a oeste na Região Nordeste, a rodovia federal BR-020 está inserida na microrregião do Vão do Paranã, localizada no leste da mencionada região. A primeira permite o acesso de Brasília ao Norte do país, através do Estado de Tocantins. A segunda é uma rota de extrema relevância para o acesso da capital federal ao Nordeste brasileiro, tendo o Estado da Bahia como “porta” de acesso. Estas rodovias estão posicionadas de forma paralela uma em relação à outra, faltando uma rodovia pavimentada que as interligue.

Além da GO-118, a região conta, ainda, com as outras rodovias estaduais não pavimentadas. Contudo o estado de conservação destas rodovias é precário. Não há outros meios de transporte para se acessar a região. Portanto, o transporte rodoviário constitui-se no principal e único meio de deslocamento de cargas e passageiros da região.

A necessidade de pavimentação de estradas secundárias, as chamadas vicinais, é evidente para que se possa completar a interligação entre os municípios da microrregião da Chapada dos Veadeiros. Há trechos em pavimentação entre Colinas do Sul e Alto Paraíso, 
o que permitirá a conclusão de um circuito rodoviário na Chapada com início em São João d’ Aliança que permitirá o aumento do Turismo na região.

Alguns municípios da região encontram-se em uma situação de total isolamento em períodos de chuva - de outubro a abril - motivado pelas características do relevo altamente acidentado e, pela falta de compactação dos solos, resultando em constantes atolamentos de veículos nas estradas da localidade neste período do ano.

Outra dificuldade, resultante desta ausência de infra-estrutura na área de transportes, está na carência de interligação entre as rotas turísticas regionais, o que dificulta a visitação local e regional, acarretando prejuízos a uma atividade econômica que pode gerar trabalho e renda, criando condições de permanência para as populações locais.

Verifica-se uma peculiaridade na região. A falta de uma estrutura rodoviária adequada produz um vazio geopolítico entre os dois principais eixos de comunicação rodoviária do nordeste goiano - BR-020 e GO-118; justamente em áreas com potencial agrícola elevado - presença de solos férteis e de belos cenários naturais. Não há provimento de estradas pavimentadas que possibilitem o acesso dos turistas nem o escoamento da produção rural.

O município de Nova Roma tem a propriedade de ser o centro urbano regional geograficamente mais centralizado desta isolada região do nordeste goiano, o qual já possui uma estrutura rudimentar de interligação com os municípios da Chapada dos Veadeiros e do Vão do Paranã sendo, portanto, a localidade - por natureza - mais propícia à disponibilização de uma estrada pavimentada que interligue estas duas microrregiões.

A concretização da atividade econômica do turismo no local necessita, portanto, de estradas em condições adequadas para receber os turistas provenientes dos estados mais próximos da região, de visitantes de todo o Brasil e, até mesmo do mundo, o que é possível dada a proximidade do aeroporto internacional de Brasília, com pouco mais de $150 \mathrm{~km}$ de distância do município de São João d’Aliança.

A realização de uma visita técnica ao percurso que liga Brasília ao município de São João d' Aliança foi realizado no mês de novembro de 2003 - dias 08 e 09/11 - obtendo-se algumas informações de interesse para os turistas ou viajantes que se interessem ou necessitem fazer o trajeto. 
As estradas de acesso de Brasília à Chapada dos Veadeiros e, mais especificamente à São João d' Aliança são a BR-020 - em um primeiro momento - e a continuidade é pela GO-118. Todo o trecho concernente ao Distrito Federal é feito na BR-020 e um pequena parcela da viagem é feita nesta estrada dentro do Estado de Goiás - sendo que um trevo se ramifica em três direções, uma em direção a Formosa -GO, outra para o Vão do Paranã e Estado da Bahia (BR-020) e a terceira para a Chapada dos Veadeiros e Estado de Tocantins (GO-118).

Todo o trajeto entre Brasília - DF e São João d’ Aliança - GO é pavimentado, com as estradas em boas condições de conservação com pequenos buracos em poucos trechos da estrada - principalmente no período de chuvas - mas, que não comprometem a segurança da viagem.

Na área do Distrito Federal, quase todo a estrada encontra-se com três vias ou pista dupla (BR-020), apenas nas proximidades da divisa deste ente federativo com o Estado de Goiás é que a pista torna-se do tipo simples. Do trevo que separa a GO-118 da BR-020 até o município de São João d’ Aliança a pista da GO-118 não é duplicada, apenas duplicando dentro do perímetro urbano deste município.

A distância de Brasília - tomando como referência a ponte do Bragueto no Lago Norte - até ao início do perímetro urbano de São João é de 146 quilômetros. As rodovias BR-020 e GO-118 estão bem sinalizadas no trajeto como um todo. Há várias placas de interesse turístico nas rodovias mencionadas. No trecho do Distrito Federal - por exemplo verifica-se sinalizações a respeito da área abrangida pelo Programa Turismo Norte do DF.

Encontra-se no percurso, também, pontos de apoio ao turista que permitem uma maior tranqüilidade na viagem, como a presença de um destacamento do corpo de bombeiros, hospitais, motéis, hotéis, entre outros locais de hospedagem próximos das rodovias. Há placas que informam sobre a presença de unidades de conservação ambiental nas margens das rodovias.

O limite de velocidade é de $60 \mathrm{~km} / \mathrm{h}$ no perímetro urbano e é de $80 \mathrm{~km} / \mathrm{h}$ nas rodovias fora deste área. Há vários avisos de curvas acentuadas com a proximidade da Serra Geral e sinalizações que avisam locais que têm freqüentes travessias de animais silvestres e de gado nas rodovias. 
O estado de conservação da estrada BR-020 da Ponte do Bragueto/Lago Norte até a cidade satélite de Sobradinho está em boas condições de trafego. De Sobradinho até a cidade satélite de Planaltina - DF encontra-se uma estrada em boas condições de conservação. Do trevo que dá o acesso a São João e Alto Paraíso (GO-118) e separa as duas rodovias, há com alguns buracos, mas é transitável, não comprometendo a segurança da viagem. No trecho do Posto Fiscal de Goiás há a necessidade de melhoria de 100m da estrada, pois este apresenta buracos e muito barro em épocas de chuva, devendo-se tomar cuidado nesta época do ano, pois esta parte da pista torna-se um pouco escorregadia. Deste ponto até a entrada para o município de Planaltina de Goiás há algumas falhas na pista. De Planaltina até um de seus distritos - São Gabriel - o estado de conservação da pista é bom, continuando neste estado até o inicio da área urbana de São João d Aliança

Os pontos de apoio entre a cidade de origem e o destino são: o posto da Policia Militar do Distrito Federal, a unidade da Policia Florestal/DF, o Posto Fiscal do Estado de Goiás, o posto policial de São João D’ Aliança.

Postos de combustível são encontrado em todo o trajeto, sendo que há a presença de diferentes distribuidoras pelas rodovias, como a Texaco, postos BR, postos Shell, postos Ipiranga e a marca independente “Advance”, não conhecida, mas com boa aparência. Neste postos encontram-se diversos serviços, como lanchonetes, restaurantes, oficinas mecânicas, borracharias, postos telefônicos. Há, também, estes tipos de serviços no decorrer da rodovia em estabelecimentos independentes de postos de combustível, como restaurantes com comidas típicas, lanchonetes, bares, pamonharia e serviços de hospedagem como o Piripau Casa de Campo (com restaurante local).

Nos centros urbanos que margeiam as rodovias encontra-se vários tipos de estabelecimentos que oferecem diversos tipos de serviços como supermercados, padarias, farmácias, churrascarias, oficinas mecânicas e borracharias, entre outros.

A maior parte da viagem conta com a cobertura dos serviços de telefonia móvel, sendo que a operadora de maior abrangência é a da empresa Vivo. Porém, nas áreas que se encontram em "baixadas” ou entre morros não é possível se realizar ou receber ligações de telefonia móvel. 
As cidades, localidades e atrativos ou pontos turísticos existentes entre cidade de origem (Brasília) e a de destino (São João d’ Aliança) são a cidade satélite de Sobradinho, o ponto de Turismo Norte/DF, a cidade satélite de Planaltina DF, a área de preservação ambiental da CAESB, a Estação Ecológica de Águas Emendadas, a Piripau Casa de Campo (hospedagem), o município de Planaltina de Goiás, os lagos próximas à estrada, o distrito de São Gabriel (distrito de Planaltina de Goiás), a rampa para vôo livre próximo a Formosa, a entrada para o município de Águas Frias de Goiás, o Atos Hotel Fazenda, o restaurante e churrascaria Atos, o restaurante Chapéu de Sol.

A vegetação predominante à beira da estrada é o cerrado e as áreas agrícolas. Há varias manchas de cerrado mais fechado com babaçu e áreas de matas ciliares e cerrado rasteiro, com suas características árvores retorcidas. No entanto, o predomínio de culturas agropecuárias vem se alastrando na região.

A média da temperatura anual no trecho da estrada é de $26^{\circ}$ Celsius, com o clima do tipo Tropical, com períodos de seca e chuva bem definidas. A umidade do ar é alta nos meses de outubro a abril e de menor precipitação pluviométrica nos demais meses.

FIGURA 03 - MAPA RODOVIÁRIO - ESTADO DE GOIÁS

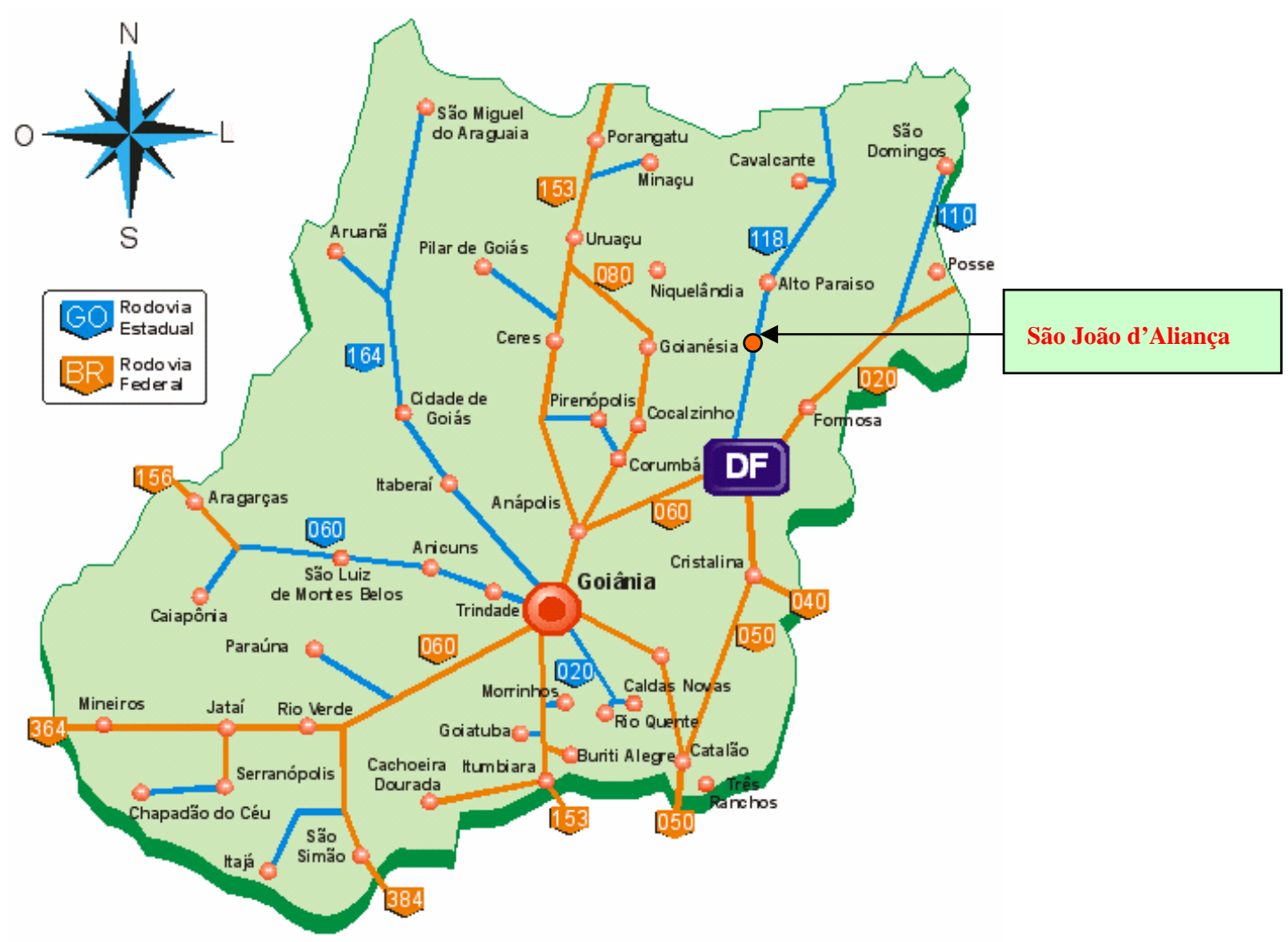




\section{C.6.2) Energia}

Outro fator restritivo ao desenvolvimento da região está relacionado à descontinuidade do fornecimento local de energia elétrica. Neste tipo de situação, mostram-se necessários investimentos que possibilitem o aumento da capacidade de geração e/ou a melhoria da transmissão e distribuição energética da localidade, para que se possa promover qualquer atividade econômica de forma adequada.

Segundo a Agência Nacional de Energia Elétrica (ANEEL), a capacidade instalada da região do nordeste goiano corresponde a 1.758,03 MW (megawatts). Isto eqüivale a, aproximadamente, 22,47 \% da energia gerada no Estado de Goiás. Sendo, portanto, necessários investimentos mais convincentes na área de distribuição de energia, não de geração em si, visto que o consumo regional é dos menores do Estado de Goiás. Há duas usinas hidrelétricas geradoras de grande porte, com mais de 30 megawatts de potência, são estas: Usina de Cana Brava (450 MW) e Usina Serra da Mesa (1.293 MW). Além disso, há usinas de pequeno porte, menores de $30 \mathrm{MW}$ (megawatts), próximas da região da Chapada dos Veadeiros: as usinas de São Domingos (14,34 MW), a de Mambaí I (0,35 MW) e a Usina de Mosquito (0,34 MW).

No Estado de Goiás, o consumo energético é da ordem de 6.229.000 Mwh, enquanto que na região do Nordeste Goiano, como um todo, este consumo não passa de 71.987 Mwh, correspondendo a 1,156\% do total consumido no Estado, algo incipiente e, que pode demonstrar a debilidade desta região neste setor em relação às demais regiões do Estado.

Há vários índices de desenvolvimento que consideram a variável consumo de energia como um fator relevante para se conhecer o modo de vida e a capacidade de produção de uma sociedade. O conforto disponibilizado para a população com a utilização de aparelhos eletrônicos e a tecnologia de produção que utiliza equipamentos propícios ao aumento da produtividade de seus produtos e serviços é o resultado esperado quando se tem um alto consumo de energia. Este problema pode ser minimizado, visto a existência de um considerável potencial hidroelétrico na região, o que permite a construção de usinas geradoras na região aumentando, substancialmente, a oferta de energia elétrica local. Porém há o problema ambiental que pode ser gerado por este tipo de empreendimento. 
Há esforços do governo do Estado de Goiás no segmento de eletrificação rural, denominado de "Programa Luz no Campo", com o qual os beneficiados contam com isenção total de contrapartida no momento de aquisição das ligações elétricas em seus estabelecimentos rurais. Geralmente, ocorre o tipo de ligação monofásica, embora a requisição da população local seja do tipo trifásico, o que permitiria o seu emprego na produção agrícola.

Em 2000, havia 3.000 (três mil) redes em execução pela CELG, empresa responsável pela distribuição de energia na região, com 364 (trezentas e sessenta e quatro)) ligações concluídas mensalmente na região da Chapada dos Veadeiros (Tabela24).

A disponibilidade de energia é um dos pré-requisitos para a redução das desigualdades regionais, atraindo empresas e turistas, o que torna os investimentos no setor elétrico, principalmente no quesito eletrificação rural, prioritários, visto a importância deste setor para o crescimento da oferta turística, da instalação de determinados equipamentos turísticos, de equipamentos e máquinas em hotéis, restaurantes, em suma de todo o aparato turístico demandado.

TABELA 24- PREVISÃO E EXECUÇÃO DE LIGAÇÕES: CHAPADA DOS VEADEIROS (2002)

\begin{tabular}{|c|c|c|c|}
\hline Municípios & Previsâo & Executado & Em Execução \\
\hline Alto Paraíso & 98 & 25 & 11 \\
\hline Campos Belos & - & - & - \\
\hline Cavalcante & 74 & - & - \\
\hline Colinas do Sul & 63 & 23 & 19 \\
\hline Monte Alegre de Goiás & 248 & 71 & 122 \\
\hline Nova Roma & 63 & 19 & - \\
\hline São João D'Aliança & 416 & - & 212 \\
\hline Teresina de Goiás & 21 & - & - \\
\hline Total & 983 & $\overline{138}$ & 364 \\
\hline
\end{tabular}

Fonte: Companhia Energética do Estado de Goiás - Celg

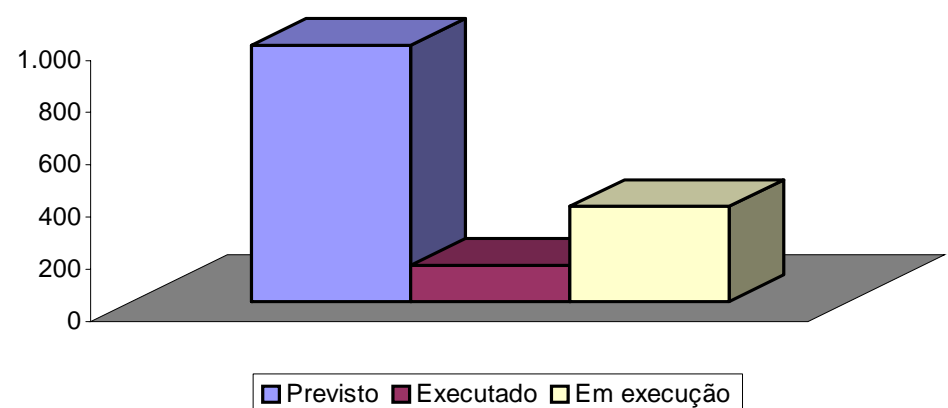

Gráfico 3. Previsão e Execução de Ligações Elétricas: Chapada dos Veadeiros (2002) 
TABELA 25 - CONSUMO DE ENERGIA ELÉTRICA: CHAPADA DOS VEADEIROS (2001)

\begin{tabular}{l|r|r|r|r|r|r|r}
\hline \multirow{2}{*}{ Municípios } & \multicolumn{2}{c|}{$\begin{array}{c}N^{0} \text { de } \\
\text { Consumidores }\end{array}$} & \multicolumn{5}{|c}{ Consumo (Mwh) } \\
\cline { 3 - 8 } & Residencial & Industrial & Comercial & Rural & Outros & Total \\
\hline Alto Paraíso de Goiás & 1.996 & 1820 & 59 & 1272 & 991 & 838 & 4980 \\
Campos Belos & 4.959 & 3.739 & 655 & 1.599 & 426 & 2.618 & 9.037 \\
Cavalcante & 1.169 & 798 & 23 & 308 & 72 & 471 & 1.672 \\
Colinas do Sul & 971 & 561 & 81 & 231 & 200 & 398 & 1.471 \\
Monte Alegre de Goiás & 1.287 & 836 & 21 & 236 & 115 & 459 & 1.667 \\
Nova Roma & 874 & 485 & 14 & 112 & 204 & 407 & 1.222 \\
São João D`Aliança & 1.799 & 1.182 & 148 & 575 & 1.095 & 735 & 3.735 \\
Teresina de Goiás & 551 & 360 & 14 & 215 & 26 & 334 & 949 \\
\hline \hline Total & $\mathbf{1 3 . 6 0 6}$ & $\mathbf{9 . 7 8 1}$ & $\mathbf{1 . 0 1 5}$ & $\mathbf{4 . 5 4 8}$ & $\mathbf{3 . 1 2 9}$ & $\mathbf{6 . 2 6 0}$ & $\mathbf{2 4 . 7 3 3}$ \\
\hline
\end{tabular}

Fonte: Secretaria do Planejamento e Desenvolvimento de Goiás - Superintendência de Estatística, Pesquisa e Informação

Legenda

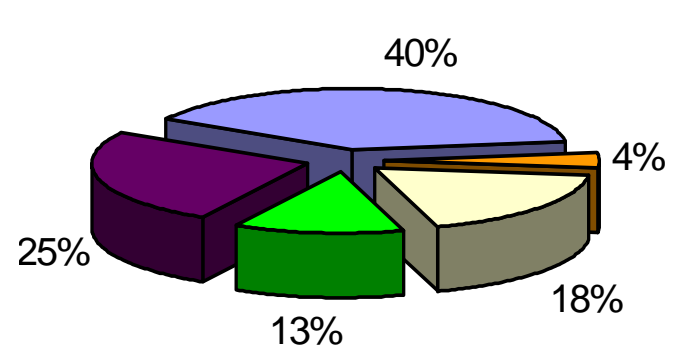

$\square$ Residencial

$\square$ Industrial

$\square$ Comercial

$\square$ Rural

$\square$ Outros

Gráfico 4. Consumo de Energia por Categoria - Região da Chapada dos Veadeiros (2001)

\section{C.6.3) Saneamento Básico}

A deficiência do saneamento básico é visível pela insignificância da rede de esgoto regional, o que cria sérios problemas sociais e de saúde pública. A política de saúde pública deve estar, portanto, integrada a política de saneamento básico, com o intuito de melhorar a qualidade de vida da população da microrregião da Chapada. A importância deste item de infra-estrutura para o turismo está na prevenção de doenças infectocontagiosas que podem espantar os turistas. 


\section{C.6.4) Telecomunicações}

Dentre as várias formas de exclusão social, destacamos a exclusão digital. Outro fator de precariedade na Chapada é constatado pelos serviços de telefonia fixa e móvel. A qualidade e a constância dos serviços são fatores limitantes para o estabelecimento de uma estrutura de comunicação capaz de alavancar o desenvolvimento regional. O isolamento provocado pela falta ou má qualidade dos serviços de telefonia impede o desenvolvimento e a geração de novos negócios, não apenas do segmento turismo, mas de vários setores econômicos. Apenas uma operadora de telefonia móvel opera na região (Vivo) de forma mais abrangente e, em muitas das localidades do nordeste goiano a Telebrasília tem escritórios que atendem aos municípios de Goiás.

O Programa Nacional de Inclusão Digital tem disponibilizado centros de informática chamados Telecentros, os quais estão disponibilizando computadores e acesso a Internet via satélite. Além disso, pode-se mencionar a instalação recente de torres de transmissão de telefonia móvel nos municípios da Chapada em geral.

\section{C.6.5) Equipamentos Turísticos}

Os equipamentos turísticos encontrados em São João d’Aliança incluem desde hotéis-fazenda, restaurantes, uma feira do produtor, até belas cachoeiras encontradas em propriedades particulares, conhecidas como RPPN (Reserva Particular do Patrimônio Natural).

No perímetro urbano pode-se visualizar a matriz da igreja católica, a sede da Agência da Capetinga com pinturas e trabalhos de artesanato de artistas locais e pode-se comprar produtos da região na feira do produtor. Porém, o forte dos atrativos turísticos da região estão localizados fora do perímetro urbano, são as cachoeiras, as trilhas ecológicas, os mirantes da Serra Geral e Vão do Paranã, as fendas da serra geral e o Complexo do Macaco.

As áreas com melhor infra-estrutura turística são a Fazenda do Pastor - onde se pode praticar rapel visitar o córrego Veadeiro, a Fazenda Andorinha, o condomínio Aldeia da Serra, localizado na Serra Geral, o Atos Hotel-Fazenda, o Buritizinho, a fazenda Farias, a 
fazenda Mingau, a antiga sede do município conhecido como distrito do Forte, o Complexo do Macaco com a área do Macaco e a do Macaquinho, onde varias reportagens da rede globo de televisão foram realizadas e o qual está em vias de ser anexado ao Parque Nacional da Chapada dos Veadeiros, ficando localizado na divisa entre Alto Paraíso e São João d’Aliança. Para visualizar alguns deste locais ver fotos em anexo (anexo A).

Os eventos culturais de São João d'Aliança são diversificados e incluem datas folclóricas, religiosas e datas cívicas. Nestes períodos observa-se um maior aumento do fluxo turístico no município. As datas folclóricas ocorrem nos meses de Janeiro, Maio, Junho e Julho, como a Folia dos Três Reis, a Folia de São Sebastião, as festas nas fazendas João Paulo e Vale do Paranã, a Folia de São João Batista e o Divino Pai Eterno, respectivamente nos meses mencionados.

As festividades religiosas ocorrem nos meses de Janeiro, Junho, Julho, Agosto Setembro, Outubro e Dezembro. Em Janeiro ocorre a festa dos Três Reis Magos no dia 06 e a de São Sebastião no dia 20. No dia 24 de Junho acontece a festa de São João Batista em várias fazendas da região. Em Julho o dia 23 é o dia do Congado (Nossa Senhora do Rosário), no dia 24 é o do Divino Pai Eterno e no dia 26 o de Nossa Senhora Santana. No mês de agosto, dia 15 é comemorado o dia de Nossa Senhora do Livramento. Dia 12 de Outubro comemora-se o dia de Nossa Senhora Aparecida e, finalmente em dezembro, nos dias 08 e 13, realiza-se as festas de Nossa Senhora da Conceição e de Santa Luzia, respectivamente.

As datas cívicas do município são os dias 01 de Janeiro e 13 de Novembro, nos quais se comemoram o aniversário da cidade e a emancipação do município. Deve-se se observar o cunho cultural destas festas, onde em todos os pousos de folia as pessoas dançam muita catira -dança regional onde se bate forte as mãos - e serve-se muita comida típica.

Há grupos de teatro da comunidade em São João d’ Aliança e um grupo de catireiros que se apresentam em datas importantes e em dias de eventos realizados no município. Além destes dois grupos, uma banda de musica se apresenta em momentos solenes. 


\section{D) ASPECTOS AMBIENTAIS}

A região da Chapada é uma região que se destaca pela exuberância de suas belezas naturais, mas também sofre com os efeitos da degradação crescente causada pelo homem. De acordo com o documento Estado Ambiental de Goiás - 2001, da Agência Ambiental, em apenas uma década, as matas nativas praticamente foram erradicadas das propriedades rurais no Estado de Goiás, revelando que apenas uma parcela de 0,8\% do território do Estado possui áreas protegidas (parques), enquanto, o percentual recomendado internacionalmente é de $10 \%$, no mínimo.

O extrativismo de madeira, a substituição das matas naturais pelas lavouras temporárias e as pastagens plantadas têm aumentado a degradação dos solos e dos recursos hídricos. Assim como o desvio do leito dos rios, a irrigação sem planejamento provoca o assoreamento dos rios e na maioria das vezes o desaparecimento de nascentes.

\section{D.1) Panorama da Proteção Ambiental no Brasil}

\section{D.1.1) Histórico}

Embora o Direito Ambiental seja um assunto ainda bastante recente, pode-se observar a existência há décadas - em todo mundo - de uma preocupação ambiental. Quando ações lesivas ao meio ambiente começaram a influir nos interesses econômicos, o mundo observou uma tendência internacional à proteção dos recursos naturais. Tal movimento estimulou - a princípio - organismos e agências internacionais, resultando, em um momento seguinte, na adoção de políticas ambientais internas pelas legislações nacionais.

Historicamente, entre os acontecimentos marcantes relacionados à proteção ambiental, a Conferência das Nações Unidas realizada em Estocolmo, em 1972, é mencionada como o primeiro evento internacional especificamente direcionado à discussão da matéria. Tal Conferência foi a primeira a considerar a questão do meio ambiente como 
um todo, já que as discussões e normas anteriores limitavam-se a aspectos específicos do problema. Os resultados desta Conferência foram sentidos em todo o mundo.

No Brasil, seus efeitos refletiram na publicação das primeiras leis ambientais nos anos 70, e seu maior desenvolvimento nos 80. Alguns exemplos são a lei federal $\mathrm{n}^{\circ}$ 5.357/67, que estabelece penalidades pela descarga de resíduos ou óleo em águas brasileiras, e a lei federal $n^{\circ} 6.803 / 80$, que estabelece regras básicas para o zoneamento industrial em áreas cujos níveis de poluição são considerados críticos.

\section{D.2) A Reserva da Biosfera do Cerrado Goyaz}

Em 1993 foi criada a Reserva da Biosfera do Cerrado - Fase I no Distrito Federal, que foi um marco importante no reconhecimento internacional do Cerrado, como área de grande interesse biológico. Com esta iniciativa, tornou-se necessária a participação de outros estados situados em áreas de Cerrado, no sentido da criação de outras fases, objetivando a reintegração deste bioma com os biomas do Pantanal, da Floresta Amazônica e da Mata Atlântica.

A proposta da Reserva da Biosfera do Cerrado Goyaz foi elaborada no ano 2000, pela Secretaria de Meio Ambiente do Estado de Goiás, com o apoio do Ministério do Meio Ambiente e do WWF - Fundo Mundial para a Natureza. Este fato se originou a partir de discussões que ocorreram nas próprias comunidades, sobretudo através de organizações da sociedade civil provenientes, principalmente, da região da Chapada dos Veadeiros, desde o ano de 1995.

A aprovação desta proposta ocorreu no dia 09 de novembro de 2000, pela UNESCO (Organização das Nações Unidas para Educação, Ciência e Cultura). As reservas têm sido planejadas objetivando três metas: conservação, implantação do desenvolvimento sustentável e aprimoramento científico.

A UNESCO fornece assistência técnica, ajuda na divulgação internacional do projeto e o acompanhamento de sua implantação. Para a implementação são determinadas três zonas: zona núcleo, que devem ser unidades de conservação de uso direto; zonas de amortecimento que devem cercar ou unir as zonas núcleos, onde as atividades econômicas necessitam ser compatíveis com práticas ecologicamente aceitáveis, de forma a garantir a 
integridade dos ecossistemas das zonas núcleos e; zonas de transição que são zonas de abrangência flexível, onde há o direcionamento para o uso sustentado.

A região da Chapada dos Veadeiros foi escolhida visando a potencialização das políticas regionais de proteção e recuperação da biodiversidade, a promoção do desenvolvimento econômico das populações residentes e a conexão da Fase I com o Estado do Tocantins. A área da Reserva tem como zonas núcleo, além do Parque Nacional da Chapada dos Veadeiros, o Parque Estadual de Terra Ronca (São Domingos) e o Parque Municipal de Itiquira (Formosa).

Uma zona de amortecimento abrange o entorno do Parque Nacional da Chapada dos Veadeiros e do Parque Municipal de Itiquira, conectando os dois através do Vão do Paranã e, se estendendo até as margens da Usina Hidroelétrica de Serra da Mesa (Colinas do Sul e Uruaçu) e até o Sítio Histórico Kalunga (Cavalcante, Monte Alegre de Goiás e Teresina de Goiás) importante área remanescente de quilombos.

A outra zona de amortecimento abrange o entorno do Parque Estadual de Terra Ronca, incluindo a APA Estadual da Serra Geral. Já a zona de transição abrange quase a totalidade da região do Nordeste Goiano, demonstrando a intenção de desenvolver em bases sustentáveis toda esta região.

Os principais sistemas naturais da região foram contemplados na abordagem estabelecida, bem como a diversidade de sistemas produtivos tradicionais do Cerrado brasileiro e suas influências sobre a biodiversidade circundante. As características histórico-culturais tiveram peso significativo para a designação das zonas de amortecimento no sítio histórico/cultural dos Kalunga e no entorno do Parque Estadual de Terra Ronca.

A Reserva da Biosfera conta com um comitê Estadual como órgão gestor composto por entidades governamentais e da sociedade civil, responsável por montar o plano de ação, a partir do qual o processo será iniciado. 


\section{D.2.1) Aspectos Físico-Ambientais}

A ampla área de distribuição geográfica da Reserva da Biosfera do Cerrado Goyaz abrange planícies e regiões montanhosas, cuja importância em termos de biodiversidade vêm sendo cada vez mais destacada, em função das diferentes fitofisionomias existentes, da influência dos biomas vizinhos que penetram a área da Reserva, bem como da relevância para a conservação dos recursos genéticos e processos ecológicos únicos, em especial, a resistência da vegetação à acidez e ao alto teor de alumínio presente no solo.

\section{D.2.2) Aspectos Econômico-Ambientais}

O turismo ecológico, rural e cultural passa a ter um papel importante; no município de São João d’Aliança e nos demais municípios da Chapada. O turismo já é responsável por uma considerável parte da movimentação econômica desta área.

A região ainda possui um potencial inigualável para a expansão do turismo ecológico, devido à diversidade de ambientes, em especial suas baixadas e serras, abrigando grandes concentrações de aves aquáticas e ninhais, além dos cursos d’água que descem por suas encostas, formando quedas d’água, cachoeiras e corredeiras no caminho.

O turismo histórico cultural ainda é pouco desenvolvido, com potenciais condições para sue estabelecimento como fonte econômica. Destaca-se a existência de um antigo quilombo próximo a São João d’Aliança, o povo Kalunga. Outras atividades econômicas usando as estruturas sociais, culturais existentes podem ser expandidas, tais como a criação de animais silvestres, o extrativismo controlado (que até então na região não tem controle) a agricultura orgânica e a produção de plantas medicinais.

\section{D.2.3) Aspectos Sócio-Ambientais}

Dentro do perímetro sugerido para a Reserva da Biosfera do Cerrado Goyaz existem comunidades estabelecidas que possuem uma filosofia alternativa de vida, com meios tradicionais de vida subsistem, desde quilombos, pescadores de subsistência, coletores de plantas e criadores de gado de forma extensiva. No interior da área proposta existe, ainda, 
um grupo humano especial, formado pelos descendentes de escravos fugidos das minas de ouro e dos índios da região. Uma população tradicional denominada povo Kalunga é originário deste antigos Quilombos. Eles mantém sistemas de produção agrícola e de pecuária de subsistência baseados na posse coletiva da terra.

\section{D.2.4) Aspectos Científico-Ambientais}

A cidade de Alto Paraíso de Goiás fica próxima a São João d’Aliança (a distância gira em torno de $80 \mathrm{~km}$ ) sendo um dos pólos atrativos de pesquisas puras e aplicadas relacionadas ao Cerrado e sua utilização racional.

O Parque Nacional da Chapada dos Veadeiros já exerce seu papel de concentrador de interesses da comunidade acadêmica. A construção da barragem de Serra da Mesa, localizada no extremo noroeste da Reserva da Biosfera, ocasionou um crescimento de pesquisas na área de influência do reservatório, em um programa de monitoramento das comunidades naturais após a formação do lago, desenvolvido em conjunto por Furnas Centrais Elétricas, Universidade de Brasília e a Fundação Pró-Natureza (FUNATURA). Essa demanda levou à existência de infra-estrutura permanente no local.

\section{D.3) As Zonas Núcleo da Reserva da Biosfera do Cerrado Goyaz}

\section{D.3.1) Parque Nacional da Chapada dos Veadeiros}

O Parque Nacional da Chapada dos Veadeiros, criado em 11 de janeiro de 1961 pelo Decreto $\mathrm{n}^{\circ}$. 49.875 como Parque Nacional do Tocantins, foi delimitado através do Decreto nº 99.279 de 06 de junho de 1990 estabelecendo sua área em 65.514 há.

Posteriormente teve sua área aumentada para 241.447 ha através do decreto s/n de 27 de setembro de 2001. O objetivo principal da criação do Parque Nacional consistiu na proteção das cabeceiras dos formadores do rio Tocantins, proteção dos campos rupestres das partes altas, de cerrados e de matas ciliares. Há ofertas de excursões e pacotes turísticos ao longo do ano, com uma maior concentração em feriados e férias escolares. 


\section{D.3.2) APA- Áreas de Proteção Ambiental}

O Projeto de criação, implantação e manutenção de Unidades de Conservação busca realizar um levantamento contínuo de locais ainda preservados que podem se tornar áreas protegidas, bem como realizar ações para o aperfeiçoamento na administração e manejo destas áreas. A APA Pouso Auto é um exemplo deste conceito que foi implantada na região em estudo. Destinada a fomentar o desenvolvimento sustentável e a preservar a flora, a fauna, os mananciais, a geologia e o paisagismo da região de Pouso Alto localizada na Chapada dos Veadeiros - foi criada em 01/10/2000, pelo Estado de Goiás, a Área de Proteção Ambiental Pouso Alto, com 872.000 ha (oitocentos e setenta e dois mil hectares), envolvendo partes dos municípios de Alto Paraíso, Cavalcante, São João da Aliança e Colinas do Sul.

\section{D.4) Potencial Turístico da Região}

Além da Reserva da Biosfera, a microrregião da Chapada dos Veadeiros apresenta um grande potencial turístico. Em alguns municípios sendo bem explorado e com uma boa infra-estrutura local, mas a grande maioria dos municípios, apesar do potencial e de fazer parte de roteiros turísticos, ainda apresentam deficiências de rede hoteleira, restaurantes e bares, entre outros.

A Chapada dos Veadeiros, o mais antigo patrimônio geológico da América do Sul, formada há 1,8 bilhão de anos, é considerada um dos maiores paraísos ecológicos do país. A Chapada dos Veadeiros está localizada no Nordeste Goiano, sendo constituída por áreas aplainadas, serras, montanhas, morros e vales. Situa-se nos municípios goianos de São João da Aliança, Alto Paraíso, Teresina de Goiás, Cavalcante, Colinas, além dos povoados de Vila de São Jorge (situado a $35 \mathrm{~km}$ de Alto Paraíso), que é a porta de entrada para o Parque Nacional da Chapada dos Veadeiros, (conta com quase 500 habitantes), Moinho e Capela, todos eles com passeios prontos e muitos lugares ainda por serem explorados. Encaixa-se na bacia do Rio Tocantins e abriga um dos últimos mananciais de águas não poluídas do planeta. 
São João d'Aliança é um ponto de passagem obrigatório para quem vai de Brasília para Alto Paraíso e para o Parque Nacional da Chapada dos Veadeiros. Além disso, o município de São João é o único com serviços bancários e caixa eletrônico de toda a região da Chapada. Muitas pessoas utilizam-se desses serviços para poderem pagar suas despesas de viagem, feitas, preferencialmente em dinheiro. A distância de oitenta quilômetros, portanto, separa Alto Paraíso do caixa eletrônico mais próximo.

Cortada pela GO-118, São João d'Aliança, ganhou importância para o turismo ecológico a partir da década de 1990. Há belas cachoeiras, como a do Mingau, trilhas e rios, como o Cachoeirinha e o rio Tocantinzinho, um dos principais formadores do lago de Serra da Mesa.

Para se locomover a qualquer um dos municípios da Chapada dos Veadeiros, deve-se passar pelo município de São João d’Aliança. É o melhor e mais curto acesso para quem vem de Brasília ou Goiânia. A rodovia está em ótimas condições de tráfego e está bem sinalizada. A pavimentação é nova. Entre os municípios turísticos mais visitados da região estão:

a) Alto Paraíso de Goiás: é a cidade construída sobre minas de cristais, um dos principais pólos de turismo ecológico do Centro-Oeste brasileiro, devido ao Parque Nacional da Chapada dos Veadeiros, situado a poucos quilômetros da sede municipal. O município recebe turistas de todo o Brasil, oferece uma grande variedade de pousadas (aproximadamente 50), restaurantes e bares (15) e atividades voltadas para a cura;

b) O município de Cavalcante: é outro local de grande potencialidade turística que vem proporcionando o aumento do movimento de turistas que passam por São João da Aliança. Foi Fundado em 1740 com o descobrimento de ouro na região. O município abriga 60\% do Parque Nacional da Chapada dos Veadeiros, além de cachoeiras, riachos e trilhas. Existe uma comunidade remanescente de um dos maiores quilombos do Brasil: os Kalungas. O fluxo de turismo ecológico cresce lentamente, e tem uma precária rede hoteleira;

c) Colinas do Sul: fica a meio caminho entre São Jorge (distrito de Alto Paraíso) e Niquelândia, nas proximidades de uma das "pontas" do lago de 
Serra da Mesa, junto ao rio Tocantinzinho. Preparou-se para ser um pólo de turismo de olho no lago - mas o desastre ecológico de 2001 fez as águas baixarem 9 metros e os investimentos ficaram à espera da volta das águas. A partir de Colinas é possível atingir pontos de turismo às margens do lago, como Mato Verde (12km), Chapada da Visão, Chiqueiro de Pedra e Vale do Lago.

Os principais estrangulamentos da atividade turismo na região estão relacionados com o pouco valor atribuído ao turismo e a cultura, o baixo poder aquisitivo na região, a não estruturação e divulgação de informações, o descaso com potenciais pontos turísticos, a falta de infra-estrutura e de consciência para atendimento ao turista, a falta de espaço adequado para eventos de impacto e a inexistência de um projeto integrado para o setor.

Aliados a isto, está a falta de estradas, problemas com energia elétrica, períodos de seca e à dificuldade financeira da comunidade para investir na rede hoteleira, bares e restaurantes. Apesar dos problemas existem empresas turísticas que fazem pacotes interessantes para a microrregião da Chapada dos Veadeiros.

\section{D.5) Legislação Ambiental}

Somando-se ao acima exposto, tratados e convenções internacionais têm representado importante papel na formação do sistema jurídico de proteção ambiental brasileiro. Entre os documentos internacionais, gostaríamos de mencionar a Convenção sobre Diversidade Biológica, a Convenção de Viena para Proteção de Camada de Ozônio e a Convenção das Nações Unidas sobre Meio Ambiente e Desenvolvimento - CNUMAD, que resultou na elaboração de importantes documentos, como a Agenda 21.

\section{D.5.1) Princípios Legais}

Além dos princípios gerais de Direito Público e Administrativo (como os princípios da Moralidade, Publicidade, Legalidade, etc.) que devem ser observados pelo direito ambiental, a elaboração de normas e políticas de proteção ao meio ambiente são especificamente orientadas por três princípios básicos: 
(I) Princípio da Prevenção

Este princípio foi estabelecido pelo artigo $2^{\circ}$ da lei 6.938/81. De acordo com suas disposições, a "Política Nacional do Meio Ambiente tem por objetivo a preservação, melhoria e recuperação da qualidade ambiental propícia à vida”. De acordo com tal princípio, as medidas que visem à prevenção de danos ao meio ambiente devem ter prioridade sobre aquelas que visem sua reparação.

(II) Princípio do Poluidor-Pagador

O princípio do poluidor-pagador foi estabelecido pela lei 6.938/81, em seu artigo $4^{\circ}$, VII. Pode ser definido como a obrigação do poluidor de recuperar e indenizar danos por ele causados ao meio ambiente. Tal princípio deve ser analisado em conjunto com o artigo 14, parágrafo terceiro, da mencionada lei, segundo o qual: "Sem obstar a aplicação das penalidades previstas neste artigo, é o poluidor obrigado, independente da existência de culpa, a indenizar ou reparar os danos causados ao meio ambiente e a terceiros, afetados por suas atividades.”

Em vista de tal princípio, e da noção de responsabilidade objetiva e solidária, os sucessores, e qualquer um que direta ou indiretamente contribua para a prática de um ato danoso ao meio ambiente, pode ser por tal ato responsabilizado.

(III) Princípio da Cooperação

De acordo com este princípio, genericamente previsto no artigo 225 da Constituição Federal, o Estado e a Sociedade devem trabalhar lado a lado para solucionar os problemas ambientais.

\section{D.5.2) Aplicação das Normas Ambientais}

É importante ressaltar certos aspectos relativos ao cumprimento das normas ambientais. O direito ambiental brasileiro estabelece sanções pelo não cumprimento dos padrões e critérios estabelecidos em lei. Advertências e multas, assim como sanções de caráter criminal, estabelecidas pelas leis 6.938 e 9.605, podem ser impostas como conseqüência da comprovada prática de infrações. 
De acordo com a irregularidade verificada, as sanções legais podem estender-se à interdição temporária ou permanente das instalações industriais, especialmente nos casos em que o dano provocado for de notável gravidade ou se a empresa for reincidente em atuações por órgãos ambientais.

A noção de responsabilidade objetiva é também de suma importância no que se refere à terceirização de serviços de caráter ambiental. Entre outros aspectos, as normas aplicáveis estabelecem que o gerador de um resíduo é por ele responsável até que sua destinação - final e adequada - se complete. Consequentemente, a empresa contratante pode ser considerada solidariamente responsável com terceiros contratados, pelo transporte, tratamento ou disposição irregular de resíduos.

A responsabilização, nos termos acima expostos, deriva diretamente do sistema legal de proteção ambiental brasileiro. Mas as empresas podem dispor contratualmente, e inclusive são aconselhadas a tanto, sobre termos e condições sob os quais se guiarão suas relações comerciais, inclusive no que tange a responsabilidade ambiental. Em outras palavras, embora não seja possível afastar a solidariedade, que deriva expressamente de disposição legal, é possível estabelecer contratualmente que uma das partes arcará com tal responsabilidade ou que a mesma restará solidária, como prescrito em lei.

No caso de verificação efetiva de danos, o órgão ambiental poderá exigir medidas corretivas de qualquer um que esteja direta ou indiretamente envolvido. As partes podem, no entanto, garantir contratualmente o direito de regresso ou de indenização.

Formou-se no Brasil uma consciência ambiental, resultado de um considerável rol de leis que vêm crescendo de forma constante desde os anos 70. Os efeitos de tal conscientização são ainda limitados, mesmo porque a mentalidade individual dos cidadãos não foi ainda atingida. Isto indica o contexto necessário para uma grande expansão da preocupação ambiental nos próximos anos, a adição de uma atitude mais responsável e proativa por parte do setor privado, assim como o desenvolvimento do sistema legal como um todo. 


\section{D.5.3) Legislação ambiental no Brasil}

Hoje, a base da legislação ambiental brasileira é dada pela Constituição Federal, promulgada em 1988. Todo um capítulo foi dedicado ao meio ambiente, e o direito a um meio ambiente equilibrado foi considerado direito fundamental dos cidadãos, como dispõe o artigo 225: “Todos têm direito ao meio ambiente ecologicamente equilibrado, bem de uso comum do povo e essencial à sadia qualidade de vida, impondo-se ao Poder Público e à coletividade o dever de defendê-lo e preservá-lo para as presentes e futuras gerações.”

A Constituição também dispõe sobre a competência para legislar nas matérias ligadas à proteção ambiental. Alguns temas específicos foram dados como de competência exclusiva da União, como os relativos às águas, energia, mineração e qualquer tipo de atividade nuclear.

Diferentemente, temas ligados a florestas, caça, pesca, fauna, preservação da natureza, defesa do solo e recursos naturais, proteção do meio ambiente, controle da poluição e responsabilidade por danos ao meio ambiente são de competência legislativa concorrente da União, Estados e Municípios. Outro interessante ponto a ser mencionado é a exigência constitucional (artigo 225, parágrafo primeiro, IV) de Estudo de Impacto Ambiental e respectivo Relatório (EIA-RIMA) para todos os empreendimentos que possam impactar de modo significativo o meio ambiente. Entre as atividades consideradas significativamente impactantes, pode-se mencionar os aterros industriais, aeroportos, estradas de rodagem, geração de energia elétrica e sistemas de transmissão de energia elétrica, entre outros. O EIA-RIMA engloba a análise do meio físico, recursos hídricos, meio biológico e aspectos antrópicos da região, entre outros. A legislação básica, que disciplina sua elaboração, são as Resoluções CONAMA 01/86, 06/87 e 10/87, no nível federal.

As leis federais 6.938, 6.902 e 7.347, as duas primeiras publicadas em1981 e a última em 1985, que conjuntamente estabelecem a Política Nacional do Meio Ambiente, são algumas das mais importantes normas. Desde a Conferência Mundial de Meio Ambiente no Rio de Janeiro, em 1992, as questões ecológicas estão ganhando importância da área. A Política Nacional relaciona padrões ambientais satisfatórios com desenvolvimento social e econômico, segurança nacional e a dignidade da vida humana. 
Na esfera federal, normas ambientais são elaboradas pelo Ministério do Meio Ambiente, pelo Instituto Brasileiro de Meio Ambiente e Recursos Naturais Renováveis IBAMA e pelo Conselho Nacional do Meio Ambiente - CONAMA.

Uma importante matéria disciplinada pela legislação ambiental federal são as diretrizes e critérios básicos para o licenciamento ambiental. Tais normas federais devem ser observadas na elaboração da legislação estadual. Em termos gerais, o licenciamento ocorre em três fases distintas e consecutivas, através da emissão de três licenças: uma Licença Prévia, uma Licença de Instalação e uma Licença de Funcionamento.

Para cada etapa do processo de licenciamento, determinados documentos e estudos devem ser apresentados ao órgão ambiental competente para análise. As licenças ambientais podem estabelecer condicionantes. $\mathrm{O}$ atendimento a tais condicionantes vincula a autorização para prosseguimento da implantação do projeto e a emissão da autorização para início de sua efetiva operação..

Anteriormente, ou mesmo durante o processo de licenciamento, o mencionado Estudo de Impacto Ambiental pode ser solicitado, dependendo das características da atividade a ser desenvolvida. Se tal estudo for efetivamente exigido, todo o processo de licenciamento pode tornar-se bem mais complexo. As licenças ambientais devem ser solicitadas basicamente em duas circunstâncias: (i) quando da implementação do empreendimento e; (ii) quando são planejadas modificações a uma atividade já licenciada.

Em 1998 entrou em vigor a lei federal no 9.605, estabelecendo a responsabilidade civil, criminal e administrativa daqueles que danificarem o meio ambiente. A principal inovação de tal lei é a tipificação como crime de diversas condutas que, até então, eram punidas por meio de multas administrativas e indenização civil. Não só as pessoas físicas, mas, também as pessoas jurídicas podem ser criminalmente responsabilizadas.

Os crimes ambientais são punidos com penas privativas de liberdade, restritivas de direitos (como prestação de serviços à comunidade, financiamento de programas ambientais, suspensão das atividades da empresa, não percepção de incentivos fiscais, entre outras) e multas penais. Segundo as disposições da lei 9.605, as multas administrativas podem atingir o valor máximo de R 50 milhões, variando de acordo com o caso concreto. 


\section{E) PLANEJAMENTO EM ECOTURISMO E O DESENVOLVIMENTO}

A metodologia proposta difere das abordagens convencionais, nas quais intervenções são arquitetadas sem a preocupação com a capacitação do capital humano. As usuais metodologias definem uma lógica operacional verticalizada - de cima para baixo determinando o que, como, para quem e onde fazer, sem a efetiva participação do público alvo. Trata-se de uma concepção anacrônica de intervenção, pois não contempla o mecanismo endógeno de alavancagem do desenvolvimento.

A proposta metodológica focaliza a questão da mobilização social como forma de mudança social. Para que tal objetivo seja alcançado é necessária uma etapa preliminar de sensibilização da necessidade de organização das comunidades. Ao se iniciar um processo de organização ou reforçar o contexto organizacional existente, a presente abordagem metodológica cria condições para que estas comunidades possam identificar suas necessidades, fazendo seus integrantes superarem suas limitações - provocadas pelo comodismo e baixa estima - tomar suas decisões e sentir-se sujeito do processo. Em suma, gera-se um processo de planejamento participativo, resultante do comprometimento das pessoas com a totalidade do mesmo, desde a sua elaboração até a sua implementação.

Nesse processo prioriza-se os níveis cognitivos, psicomotores e afetivos das comunidades de forma contínua, dotando-as de elementos fundamentais para alcançar um resultado de êxito. Desta forma exercita-se todo o seu potencial na construção de uma nova consciência coletiva, dada a inversão da lógica operacional. O propósito central de uma proposta de desenvolvimento sustentável, neste enfoque, consiste em implementar iniciativas e ações que gerem uma maior responsabilidade social, um nível mais elevado de conscientização da necessidade de se conservar o meio ambiente, para que se possa atingir uma maior eficiência econômica local. Este desenvolvimento é fruto da interação das dimensões social, ambiental e econômica.

A questão do desenvolvimento sustentável como prioridade em um novo contexto internacional de globalização é defendido nos inúmeros encontros ocorridos em todos os cantos do planeta. A nova ordem mundial é permitir a evolução humana com equidade para todos, com a qualidade de vida como resultado primordial a ser alcançado. A 
qualidade de vida da população mundial está intrinsecamente ligada ao fator de preservação ambiental. Não há como se pensar no viver com qualidade se o ambiente no qual se está inserido não tem as condições mínimas para que isto ocorra.

O meio ambiente é constituído de recursos escassos, que podem ou não ser renováveis. Um ambiente preservado é um fator indispensável para que se possa planejar a alocação efetiva e coerente dos poucos recursos necessários ao alcance do bem-estar humano.

Qualquer tipo de produção exige a utilização de recursos, sejam estes de qualquer ordem ou tipo. Portanto, necessita-se de um tipo de produção sustentável, ou melhor, que se perpetue sem que ocorra o esgotamento dos recursos existentes no planeta. A questão surgida é como dar continuidade à satisfação de necessidades humanas cada vez mais sofisticadas e amplas, consideradas individualmente e no seu todo?

A implantação prática de um sistema produtivo sustentável tem sua origem no embasamento teórico do conceito de desenvolvimento sustentável. Por isso, o termo desenvolvimento e meio ambiente tem sido tão discutidos nos últimos tempos. Um dos modos mais adequados para se garantir uma utilização racional dos recursos existentes na natureza é a utilização de uma ferramenta administrativa conhecida como planejamento.

O planejamento de atividades, serviços, produção, projetos, programas, em suma, de todos os meios ou processos de efetivação ou ação originados em um processo de tomada de decisões, é vital para que o processo de desenvolvimento humano, em sentido amplo e, a preservação ambiental sejam conquistadas. Há vários tipos de planejamento, mostrandose o mais adequado para a questão de preservação ambiental aquele que se utilize de conceitos baseados na questão de sustentabilidade, seja ela econômica, social, política, cultural ou ambiental.

A participação da comunidade no processo de planejamento e execução das ações definidas como prioritárias para o desenvolvimento territorial de uma localidade é um dos componentes básicos para a efetivação do planejamento de qualquer tipo de atividade humana considerada sustentável.

Uma das metodologias de planejamento utilizadas é a baseada no método DLIS (Desenvolvimento Local, Integrado e Sustentável). Está é a metodologia de planejamento 
empregada no município em estudo, São João d’Aliança, Estado de Goiás. Esta metodologia consiste na sensibilização comunitária da necessidade de participação da população em prol do desenvolvimento municipal. Em uma próxima etapa, formam-se grupos locais de discussão - chamados Fóruns de DLIS - que têm a missão de estipular os objetivos a serem alcançados e as ações desempenhadas pela comunidade para atingi-los para que o município se desenvolva.

Uma agenda - contendo as ações prioritárias a serem atingidas - é elaborada nos Fóruns de Desenvolvimento Local, do tipo urbano e rural. Estas agendas consistem em demandas públicas e, em ações a serem concretizadas pela comunidade ou reivindicadas às autoridades públicas em prol do desenvolvimento municipal. Ações estas condizentes com a realidade do município.

A definição das atividades prioritárias em uma agenda pública - propostas pela própria comunidade - focalizam a busca do consenso sobre as questões consideradas relevantes para a melhoria da qualidade de vida da população e para o aumento de competitividade econômica do município. O levantamento das demandas públicas efetuado pela própria comunidade gera a credibilidade e o envolvimento necessários para que a concretização de um planejamento municipal venha a ser bem sucedido.

Um das prioridades definidas pela agenda de DLIS (Desenvolvimento Local Integrado e Sustentável) do município de São João d’Aliança é o planejamento do ecoturismo municipal e - de forma mais ampla - o regional, como fator de desenvolvimento da localidade e da região na qual o município está inserido. Em um segundo momento tem-se organizado a microrregião da Chapada dos Veadeiros - em fase de concretização com o Acordo Cerrado - e, por último, tem-se pensado na elaboração de um planejamento que abrangerá toda a região conhecida como Nordeste Goiano, constituindo esta visão em um objetivo mais amplo a ser alcançado futuramente.

O planejamento do ecoturismo em São João d’Aliança está, portanto, considerando que em um futuro próximo haverá a possibilidade de se ter uma integração regional. Um outro caminho a ser trilhado para a obtenção do desenvolvimento ecoturístico não restrito apenas à sua localidade, mas a toda uma região que tem - como sua mola propulsora desenvolvimentista - no ecoturismo um de seus fatores de desenvolvimento sustentável. 
A crença na capacidade do ser humano em superar obstáculos e propor soluções está fundamentada nos processos de desenvolvimento baseados na capacitação dos atores sociais. Eficácia, eficiência e efetividade são obtidas através da aplicação do conhecimento adequado à realidade socioeconômica local. Para que isso ocorra é fundamental despir-se de velhos hábitos e buscar o aperfeiçoamento de práticas usuais por intermédio de processos de produção, gestão, e de tomada de decisões mais recentes.

Durante o processo de capacitação da metodologia DLIS, a comunidade adquiriu conceitos necessários para a tomada da iniciativa da mudança, através de uma postura proativa, protagônica, empreendedora, buscando o conhecimento (o que fazer e por que fazer), a habilidade e a compreensão dos métodos (como fazer), e a vontade (querer fazer), adequando seus hábitos para a condução de sua atividade produtiva e de sua vida pessoal com qualidade; a melhoraria do nível de organização e, entendendo o termo organização como um instrumento de desenvolvimento social, político e empresarial.

A participação de entidades representativas como membros da prefeitura, integrantes de assentamentos rurais, guias turísticos, entre outros agentes que tem o intuito de alcançar - através da cooperação - objetivos comuns em ramos como o ecoturismo (considerado como elemento de coordenação de sistema ou cadeia de atividades ecoturísticas e ações interligadas de vários entes formadores do ramo de negócios turismo, promovendo a integração e o equilíbrio da receita entre os elos que a compõem) e a preservação do meio ambiente permitem a conscientização da comunidade de que precisa-se não somente do produzir, mas produzir sempre, de forma sustentável e contínua, não comprometendo a oportunidade das gerações futuras.

Durante o processo de estudos comparativos, caracterização e análise do município, percebeu-se que a busca de soluções de curto prazo e o imediatismo de ações advindas de políticas públicas precipitadas, foram insuficientes para a obtenção de um desenvolvimento sustentável na localidade de São João d’ Aliança. Em contrapartida, os resultados de uma proposta de desenvolvimento planejado surtem efeitos, a médio e longo prazo, quando há o comprometimento e a integração institucional, a gestão compartilhada, a sensibilização, a mobilização e a participação da comunidade.

Neste processo as instituições públicas e privadas assumem um papel de extrema relevância. Às primeiras, cabe o papel de indutora do desenvolvimento, oportunizando 
efetivas condições culturais, sociais e econômicas. O papel do Estado é o de promotor do desenvolvimento; o qual deve prezar pelo maior envolvimento do setor privado; pela integração institucional (ações despenhadas de forma cooperativa) e pela constituição de consórcios intermunicipais, considerando-os mecanismos de desenvolvimento que podem alavancar o ecoturismo na região. Isto vem sendo realizado no município, certos de que as características municipais adequaram-se à metodologia de DLIS (Desenvolvimento Local Integrado e Sustentável).

As mudanças culturais exigem que os hábitos, valores, crenças e atitudes das pessoas sejam trabalhados, tanto no comportamento das próprias pessoas quanto na postura das instituições. A mudança não ocorre de uma hora para outra, mas para que possa acontecer faz-se mister quesitos como liderança, clima favorável, entendimento, convicção e perspectivas positivas.

Nessa perspectiva sugere-se, conforme a argumentação proposta, a implementação de programas integrados de desenvolvimento regional, através da formação de consórcios intermunicipais - parcerias entre os municípios de uma mesma região - que incluam o poder público e a sociedade em prol do fortalecimento da atividade do ecoturismo local.

A proposta busca não só diagnosticar problemas, mas operacionalizar o programa e obter uma maior integração entre os setores público e privado. A proposta de promover articulações entre os municípios vizinhos à São João d’Aliança, de características semelhantes, sendo essencialmente rurais, só poderá ter alguma chance de alcançar êxito se estiver vinculada a uma integração regional que permita vislumbrar tendências e prioridades e a concentrar esforços em um direcionamento comum. No caso, o direcionamento é o ecoturismo como um fator de desenvolvimento sustentável local.

Há a necessidade de adotar, no gerenciamento institucional, os princípios e as ferramentas da gestão participativa para que sejam criadas as condições adequadas de cooperação, preservação ambiental e competitividade.

O Plano Estratégico de Desenvolvimento Municipal e, posteriormente, um plano de maior âmbito, o regional, é a oportunidade do município planejar seu futuro com os demais municípios do Nordeste Goiano. A participação institucional da comunidade local e de suas congêneres vizinhas é outra alternativa estratégica para viabilizar-se a busca da melhoria da qualidade de vida de suas populações. Este procedimento deve ser elaborado 
com enfoque sistêmico, participativo e descentralizado, consolidando-se como um instrumento para a gestão proativa dos municípios, definindo um modelo de co-gestão, partilhando tarefas, responsabilidades e resultados.

Um plano de desenvolvimento municipal tem na pauta da sociedade, na agenda governamental e nos elementos de desenvolvimento a sua essência. Portanto, a participação das comunidades locais e de suas lideranças torna-se indispensável para a efetivação do desenvolvimento sustentável.

O ecoturismo é tido como uma das atividades que menos agridem a natureza. A sua viabilidade está na tendência mundial de disseminação do consumidor da natureza, com a conseqüente busca das pessoas pelo "verde” e, a fuga das pessoas dos tumultos dos grandes conglomerados. Neste item está, também inserida a necessidade do planejamento municipal no que tange os espaços, equipamentos, atividades turísticas motivadas pelo grande fluxo de pessoas para que, segundo Ruschmann (1997, pág. 9) “se possa evitar danos sobre os meios visitados e manter a atratividade e os recursos para as gerações futuras”.

A experiência de planejamento no município de São João d’Aliança envolve um modelo de gestão próprio, o qual respeita a cultura local e a percepção de tempo adequada às suas populações. O ritmo de vida das localidades é diferente dos grandes centros, não podendo ser desconsiderado o fator "percepção do tempo" para que não se prejudique o andamento do processo. A eficiência e a flexibilidade dos sistemas institucionais devem ser buscadas de forma a preservar a continuidade do planejamento local.

A descentralização e interiorização da ação governamental visa garantir uma maior eficiência e eficácia à atuação administrativa oficial. Essa experiência - de elaboração dos planos regionais - é adotada como base do conceito de desenvolvimento sustentável, considerado como ponto de referência para o trabalho de formulação de Planos de Desenvolvimento Regional Sustentáveis.

O enfoque metodológico deve ser orientado por uma concepção de planejamento considerado como um processo técnico e político. O processo de mobilização das sociedades regionais e a sua sustentabilidade político-institucional devem ser buscados adotando-se na metodologia a participação dos atores sociais e dos agentes públicos, de modo que o envolvimento da população assegure a sustentabilidade das propostas e dos 
projetos contidos nos Planos, garantindo assim a sua implementação. Este resultado vem sendo obtido em São João d'Aliança, o que se verificou em reuniões de discussões sobre o futuro do município e da região do Nordeste Goiano - realizadas neste município.

Ao final da elaboração dos Planos, mostra-se coerente o ato de instituir os Fóruns de Desenvolvimento Regional com a participação desses atores sociais e agentes públicos regionais, para garantir o gerenciamento e o acompanhamento dos produtos consubstanciados nos Planos Regionais. Os fóruns urbano e rural estão inseridos essa etapa.

$\mathrm{Na}$ construção do diagnóstico, seis dimensões da realidade regional devem ser contempladas: a econômica, a social, a ambiental, a infra-estrutura, a político-institucional e a científico-tecnológica. A leitura da realidade é feita mediante a identificação dos problemas e potencialidades de cada dimensão.

Paralelamente, a identificação das oportunidades e ameaças externas no contexto regional e a construção de cenários que orientem a definição do futuro desejado para o município -e de forma mais ampla para a sua região - devem ser delimitados. A partir desses cenários, são definidos o modelo de gestão e as opções estratégicas.

O fio condutor do debate para a construção do futuro local e regional desejado é o conceito de desenvolvimento sustentável que, num processo de discussão coletiva, torna-se expresso no nível de qualidade de vida, estando esta garantida, especialmente, pelo acesso aos serviços básicos de excelência nas áreas de saúde, trabalho, educação e segurança.

A noção de desenvolvimento sustentável - implementada em um planejamento municipal e regional - permite a incorporação de reflexões e equaciona desafios decorrentes de sua aplicabilidade em realidades diferentes. Assim, o desenvolvimento é definido como um processo de mudança social e de elevação da qualidade das oportunidades de uma sociedade.

$\mathrm{Na}$ aplicação desse enfoque são considerados como elementos fundamentais a democracia e a participação para que se possa atingir os objetivos da sociedade contemporânea relacionados ao alcance do desenvolvimento sustentável. Com efeito, a participação do cidadão torna-se a condição principal para a sustentação e a viabilidade política necessárias ao desenvolvimento sustentável de uma localidade. 
Nesse caso, o planejamento como processo técnico e político considera a participação dos atores envolvidos e comprometidos com a transformação de uma realidade para um outro patamar, como uma exigência para a sustentabilidade política das decisões tomadas no processo de planejamento.

Entende-se o planejamento como parte do processo político de tomada de decisão sobre as ações que irão interferir no futuro, constituindo um espaço privilegiado de negociação entre os atores sociais, confrontando e articulando interesses nas definições de alternativas para a sociedade.

Segundo Bacelar e Bezerra, a relação entre a análise e a elaboração técnica, de um lado, e o processo político de decisões de escolhas, de outro, constitui o grande desafio para o planejamento do desenvolvimento sustentável. São duas lógicas a serem confrontadas: a lógica política e a racionalidade técnica. Enquanto o trabalho técnico deve, fundamentalmente, gerar informações e oferecer o suporte racional e analítico aos atores sociais para que eles possam escolher de forma mais apropriada as alternativas, as decisões de escolhas são sempre políticas, correndo-se o risco de prevalecerem interesses inconsistentes com as possibilidades concretas de sustentabilidade do desenvolvimento.

(Bacelar e Bezerra, 1999, pág. 9).

Portanto, o Plano é um produto técnico e político que resulta do processo de planejamento, considerado apenas um estágio do planejamento e um instrumento das escolhas e decisões efetivas, por meio do qual podem ser organizadas e articuladas as ações, catalisando agentes e instrumentos de intervenção.

Trata-se de um instrumento de negociação política que serve de referencial na busca de apoios financeiros necessários à sua implementação. Nesses casos, a aplicação do enfoque teórico-conceitual nos planos de desenvolvimento regional sofreu adaptações na sua operacionalização, sobretudo no que se refere aos pilares teóricos: o desenvolvimento sustentável e a concepção de planejamento. As dificuldades na aplicabilidade se expressam na tradução dos conceitos em instrumentos concretos de interpretação da realidade e formulação das opções estratégicas resultantes do processo de planejamento do desenvolvimento sustentável. 
A transferência de unidades administrativas governamentais com autonomia administrativa e financeira - necessárias para a elaboração de políticas públicas condizentes com a realidade da região - deve ser efetuada. Os Centros Regionais da CELG, da Secretaria Regional de Educação, da SANEAGO, de Segurança Pública, do INCRA, da Agência Ambiental, e da Agência Rural são apenas alguns dos exemplos de unidades administrativas que podem ser transferidos para esta região para melhor atender às demandas publicas regionais. No entanto, esta realidade ainda não se efetivou. Vários deste centros regionais de planejamento estão distantes dos municípios atendidos.

O auxílio de entidades privadas - ramo empresarial - de organizações não governamentais e de organismos internacionais pode auxiliar os agentes de mudança locais na captação de recursos financeiros e no fortalecimento do capital humano regional. Empresas de cartões de crédito podem financiar a preservação do Cerrado brasileiro, como já ocorre nos resquícios da Mata Atlântica com o programa de apoio financeiro chamado “SOS Mata Atlântica”, caso de instituições financeiras que repassam parte de seus lucros para a implantação de projetos ambientais neste bioma brasileiro.

O incentivo à participação de alunos universitários em projetos ambientais e as consultorias do SEBRAE para aproveitamento empresarial das potencialidades locais artesanato, pintura, esportes radicais, roupas e tecelagens, gastronomia e a promoção dos produtos típicos da região como o frango caipira, o pequi, o cajuzinho, o barú, entre outros - podem criar novos atrativos turísticos na localidade, o que já vem ocorrendo na casa da Capetinga - em São João d’Aliança - desde o dia treze de novembro de 2003 com a instalação de locais de vendas destes produtos na sede do Acordo Cerrado no município.

O turismo científico e a pesca esportiva oferecem outras possibilidades de atrações turísticas regionais. A agricultura orgânica pode ser trabalhada para criar uma imagem benéfica ao ramo gastronômico local criando um outro atrativo que a ser descoberto nesta região ainda pouco conhecida do turismo nacional, podendo vir a ser mais um "ponto” a contribuir para o desenvolvimento sustentável de uma região de belezas singulares no Brasil. 


\section{METODOLOGIA}

A metodologia utilizada para a elaboração do presente trabalho foi a de coleta de dados por intermédio de pesquisas bibliográficas, visitas técnicas ao local sede do objeto de estudo, aplicação de entrevistas com as principais lideranças fomentadoras do desenvolvimento e do ecoturismo no município de São João d'Aliança, participação em reuniões dos fóruns de desenvolvimento da localidade e da região da Chapada dos Veadeiros - organizadas pela comunidade local - e, pela disponibilização de documentos pelas repartições públicas do Estado de Goiás. Portanto, entre os tipos de pesquisas realizadas, encontram-se a do tipo bibliográfica e a de campo, as quais são empregadas para o embasamento teórico e experimental do presente trabalho monográfico.

O uso de metodologias múltiplas de pesquisa foi necessária para convalidar o trabalho apresentado. Entre estas metodologias pode-se citar a observação participante (observador participou de reuniões comunitárias a respeito de desenvolvimento sustentável no município abordado), a análise de documentos disponibilizados pelo Estado de Goiás (planilhas, gráficos e documentos fornecidos pelas secretarias e agências estaduais) e a aplicação de uma entrevista com as diversas lideranças municipais.

A observação participativa ocorreu nos meses de outubro e novembro de 2003 sendo que o observador participou de reuniões comunitárias destinadas às discussões sobre a questão de desenvolvimento do município de São João d' Aliança, localizado na microrregião da Chapada dos Veadeiros, na região Nordeste do Estado de Goiás. O prospecto de um destes eventos - que se refere à inauguração da Sede do Acordo Cerrado encontra-se em anexo (anexo C).

A elaboração das entrevistas ocorreu em cinco dias - do dia 25 a 30 de outubro de 2003 - sendo que as mesmas foram aplicadas no município de São João d’ Aliança no período de 03 de novembro a 10 de dezembro de 2003. A aplicação das entrevistas focalizou as opiniões das lideranças locais do município sobre os temas turismo, ecoturismo, preservação ambiental e economia local. Esta escolha ocorreu devido à capacidade destas pessoas influenciarem as idéias de uma relevante parcela da população em análise, direcionando diversas ações comunitárias concretizadas no município. O 
número de pessoas computadas nesta pesquisa foi de quinze pessoas no total de entrevistados. Nos anexos deste trabalho pode-se encontrar o roteiro da entrevista realizada (anexo B) e a lista das lideranças entrevistadas (anexo D).

A entrevista aplicada é do tipo semi-qualitativa. As perguntas abertas foram elaboradas de forma a proporcionar respostas que puderam ser agrupadas em termos percentuais, no intuito de disponibilizar resultados que permitam uma leitura mais facilitada. A tipologia da entrevista empregada é a estruturada, a qual consiste em perguntas determinadas - para se evitar uma excessiva liberdade do entrevistador - visto ser o tempo para a concretização da pesquisa, um dos fatores limitantes para a conclusão do trabalho - o que poderia comprometer a validação dos resultados obtidos se não fosse respeitado.

Para a análise dos resultados foram utilizadas tabelas e gráficos da ferramenta de informática Excel, os quais permitiram a análise e tabulação de diversos documentos adquiridos juntos às repartições públicas do Estado de Goiás. A utilização de fórmulas matemáticas - em planilhas Excel - permitiu que fossem feitas comparações entre o município de São João d’ Aliança e, os demais componentes da microrregião da Chapada dos Veadeiros e da região do Nordeste Goiano, de modo mais amplo. O agrupamento de respostas parecidas, considerando-se palavras sinônimas e interpretações parecidas foi utilizado para a transformação dos dados provenientes das entrevistas em números percentuais - de melhor visualização para análises mais apuradas. 


\section{RESULTADOS E DISCUSSÃO}

Os principais resultados alcançados do presente trabalho estão: na implementação do ecoturismo como atividade promotora de desenvolvimento municipal, na conscientização da comunidade de São João d'Aliança da necessidade de um plano de desenvolvimento sustentável para a localidade - focando a melhoria da qualidade de vida, a conservação do meio ambiente e o envolvimento institucional de órgãos governamentais e não governamentais - e na integração regional para que os objetivos da região sejam alcançados junto com as demais comunidades circunvizinhas. Nas palavras de uma das lideranças locais, a questão do desenvolvimento sustentável do município está em "pensar global, mas agir local”

Para a comprovação dos resultados obtidos, foi utilizado - primeiramente - o instrumento de coleta de dados conhecido como observação participativa, para que se pudesse conhecer o grau de influência de líderes locais no direcionamento das ações comunitárias em prol do desenvolvimento municipal. Após a participação em reuniões de discussão a respeito do desenvolvimento regional ocorridas em São João d’ Aliança, percebeu-se que em um ente federativo de pequeno porte, as pessoas têm um maior respeito por seus líderes nas suas relações interpessoais. Observado este fato, optou-se pela realização de entrevistas com as lideranças comunitárias de São João, para se conhecer o grau de sensibilidade da população em relação às questões de desenvolvimento sustentável, ecoturismo e planejamento deste município na visão de seus líderes.

A utilização de entrevistas do tipo semi-qualitativa permitiram - com o agrupamento do somatório de respostas parecidas ou que continham palavras sinônimas - contabilizar-se as respostas abertas obtidas, transformando os resultados em termos percentuais. O roteiros destas entrevistas encontra-se em anexo neste trabalho monográfico(anexo B).

No ponto referente à implementação do ecoturismo e à preservação ambiental no município, encontrou-se - com o auxílio das entrevistas realizadas - uma forte relação entre a sensibilização das pessoas e o processo de mudança social. Entre as respostas das pessoas a respeito da relevância da atividade turística para o município, observa-se uma concordância geral - de $100 \%$ dos entrevistados - com o fato de considerarem este tipo de 
atividade algo já existente em São João d’ Aliança mas, que ainda falta muito a se fazer em várias áreas para que se possa tornar o turismo uma atividade de maior relevância na participação da economia local.

Todos os entrevistados - ao responderem à primeira questão do questionário encontrado em anexo (anexo B) - consideraram o turismo uma atividade econômica geradora de emprego, alguns - 73,33\% dos entrevistados - a consideraram como a única atividade econômica viável nesta região, salientando que as principais vantagens de se desenvolver o turismo local está na geração de renda, no emprego e na possibilidade de melhoria do visual da própria cidade, o que já vem sendo percebido. Esta percepção é evidente, mas ainda lenta.

Há construções e melhorias de várias áreas públicas da cidade, como a ampliação da matriz da igreja católica, a previsão de construção de uma praça - com o fechamento de uma das ruas da cidade localizada em uma área central onde se encontram alguns dos principais atrativos do perímetro urbano - a conclusão e funcionamento de uma feira do produtor, a construção da sede da Agência de Desenvolvimento, a Casa da Capetinga, entre outras melhorias que já se encontram na localidade.

Estas melhorias no visual da cidade estão relacionados com o aspecto de infraestrutura do turismo municipal, o qual necessita de atrativos turísticos e de estrutura de apoio que possam proporcionar ao município uma imagem positiva junto aos turistas e visitantes. Este fato pode permitir que o município alcance o status de pólo turístico, como ocorreu com o município vizinho de Alto Paraíso de Goiás.

Um número considerável dos quinze entrevistados - mais de 66,67\% entrevistadosconsideraram que a conservação ambiental pode ser obtida com o incentivo ao turismo, o que possibilitaria a redução de pessoas empregadas em atividades que degradam o meio ambiente. A relação entre ecoturismo e a questão ambiental está no fato de ser o segundo, matéria-prima essencial para que este tipo de turismo possa efetivar-se como atividade economicamente viável. Não há ecoturismo em uma localidade se não há uma natureza preservada e, não há uma natureza preservada se as pessoas - que habitam a localidade não estiverem sensibilizadas da importância do meio ambiente para a continuidade do processo de implantação e manutenção do ecoturismo local. 
A presença de unidades de conservação, de áreas de proteção ambiental e de Parques Naturais na região criam um condicionamento especial sobre a população local, gerando um sentimento de comprometimento com a conservação de seu maior patrimônio, a biodiversidade da natureza. Dos entrevistados, $86,67 \%$ se referem ao ecoturismo como a única atividade econômica aceitável na região, o que mostra a consciência ambiental de uma boa parcela dos líderes locais. Segundo a entrevista, estão acontecendo trabalhos de educação ambiental nas escolas, mas as ações nesta área são percebidas como ainda ínfimas. Há projetos de educação ambiental a serem realizados nas escolas no ano de 2004. O próprio Fórum de Desenvolvimento tem uma escola que trata do assunto. A WWF disponibilizou professores no município para atender esta nova demanda.

A única reivindicação dos habitantes desta região é um maior respeito das autoridades governamentais à legislação, visto que muitas decisões são tomadas pelos dirigentes do país sem se considerar dados técnicos e a legalidade de ações como no caso das desapropriações arbitrárias, fato que ocorre de forma constante e repetitiva.

A ampliação do Parque Nacional da Chapada dos Veadeiros, por exemplo, não foi realizada de acordo com o processo legal vigente no país. Desapropriações de terras de mais de quatrocentas famílias foram decididas pelo governo federal, interessado em receber o título de Patrimônio Natural da Humanidade, o que só seria possível com o aumento da área do Parque. Não se realizou uma audiência pública, conforme prevê a legislação nacional para que a ampliação fosse executada. A nova área do Parque pertence ao município de São João d’ Aliança. É o chamado “Complexo do Macaco”, localizado na divisa com Alto Paraíso.

As leis de turismo - em especifico - não foram consideradas como fatores impeditivos para o melhor andamento da atividade turística no município, o que é percebido pela resposta de 93,33\% dos entrevistados. Na entrevista muitos líderes comunitários mencionam que as leis existem e são boas, mas que ainda não são cumpridas. Os mesmos mencionaram que se as leis fossem cumpridas, muito provavelmente o turismo estaria em um melhor estágio no município. Com relação à legislação municipal que trata do ecoturismo, algumas pessoas - 26,67\% -mencionaram não conhecê-las e, as demais 73,33\% afirmaram que há poucas leis deste tipo originadas neste ente federativo, o que dificulta a implementação do ecoturismo no município. 
Mais da metade das lideranças entrevistadas - 73,33\% dos entrevistados - disseram conhecer o termo Ecoturismo, salientando - de alguma forma - que o mesmo focaliza os atrativos naturais, as tradições e os produtos turísticos oferecidos pela comunidade ao visitante ou turista. Verifica-se também a não distinção entre os termos Ecoturismo e Turismo Ecológico por 93,33\% dos entrevistados.

Entre os pontos ecoturísticos citados, pode-se mencionar a fazenda do Pastor, a Aldeia da Serra, o córrego Veadeiro, a fazenda de café do Japonês, o Vão do Paraná (mirante), a fazenda Andorinha, o Atos Hotel-Fazenda, a fazenda Buritizinho, a fazenda Farias, a fazenda Mingau, o distrito do Forte, o Macaco, o Macaquinho, o Caminho de Muquém e o rio Tocantinzinho. A fazenda Andorinha foi o local citado como o de maior beleza, constituindo-se em uma atratividade turística por natureza, na opinião de cerca de 53,33\% dos entrevistados. A Cachoeira do Cantinho (citada por 40\% dos entrevistados), a Bocaina do Farias (lembrada por33,33\% dos líderes comunitários) e a Cachoeira do Pastor (mencionado por 33,33\% dos entrevistados) foram outros atrativos turísticos também citados. São lugares considerados perfeitos para a pratica de esportes radicais. Algumas ainda precisam de um maior investimento para adequar-se a tais práticas desportivas.

O turismo sustentável foi mencionado como benéfica para todos, desde o dono do hotel, até a pessoa que tece colares com sementes do cerrado. Também é mencionado como uma atividade econômica justa e que preserva o meio ambiente, palavra tomada por um sentimento de pertencimento. As pessoas chegaram à conclusão de que a água, a vegetação do cerrado e os demais recursos disponibilizados pela natureza, podem não ser tão renováveis como pensavam e, caso não cuidem desse patrimônio, logo os seres humanos - as pessoas entrevistadas sempre usavam a primeira pessoa do plural - serão a próxima espécie em extinção.

Há no município de São João d' Aliança lugares apropriados para a prática de esportes radicais. A fazenda do Pastor e a Andorinha estão equipadas para atender as modalidades de cannoeing e rapel e, foram locais citados por 53,33\% dos entrevistados quando perguntados sobre os pontos do município mais propícios para a prática destes tipos de esporte. A estrutura da fazenda Andorinha está pronta e bem equipada para estes tipos de atividades turísticas. Já ocorreram competições de esportes radicais no município como competições de bike, o rali dos sertões e a corrida de aventura patrocinada pela Disbrave (Volkswagem). 
Os entrevistados consideram que o visual da cidade precisa ser melhorado para atrair mais turistas - total de $100 \%$ das respostas continham esta preocupação. Entre as idéias surgidas para reverter esta situação, foram mencionados processos de mutirão para a retirada de lixo de lugares considerados pontos turísticos, a busca de recursos governamentais para a melhoria de prédios e lugares públicos - como no caso da construção de uma praça em frente à matriz da igreja católica da cidade e - a concessão de crédito financeiro de bancos destinados à melhoria da estética dos estabelecimentos comerciais.

Outro fator de atratividade turística citado é a melhoria do atendimento e do visual dos restaurantes - 60\% dos entrevistados lembraram deste item. Foi também citada a necessidade de desenvolvimento de um gerenciamento dos atrativos turísticos, ou melhor, a sistematização e integração dos agentes da cadeia turística para atender aos turistas de forma mais organizada e efetiva - 6,67\% dos entrevistados. As ruas precisam de um melhor programa de limpeza e recolhimento de lixos, os canteiros não estão muito bem cuidados, há ainda poucas opções de hospedagem e as pessoas não estão capacitadas para receber e melhor atender ao turista. A Prefeitura é considerada a principal responsável por esta situação, sendo que a comunidade se mostra aberta para dialogar e auxiliar na limpeza da cidade - resposta de $26,67 \%$ dos entrevistados.

São João d' Aliança é um município que integra programas governamentais de incentivo ao turismo. Mencionou-se nas entrevistas - 66,67\% - o Programa Nacional de Municipalização do Turismo - PMNT do governo federal, o qual está na fase de conclusão - terceira e última fase concluída na última de dezembro de 2003 com a elaboração do Plano Diretor de Turismo Municipal.

Este Plano Diretor é elaborado com a participação comunitária. Este fato contribui para se perceber a importância da mobilização social para a obtenção do desenvolvimento econômico, social e cultural local. As pessoas conhecem a realidade de sua localidade. A participação comunitária é de vital importância para o envolvimento da comunidade com as ações que possam alavancar o turismo e outras atividades que proporcionem o almejado desenvolvimento territorial.

No âmbito estadual o Projeto “Caminhos da Biosfera” está em andamento com as parcerias entre o Fórum de DLIS (Desenvolvimento Local Integrado e Sustentável), o 
SEBRAE e a Agência Goiana de Turismo - AGETUR -órgão estadual de políticas públicas no segmento turismo - item mencionado por $20 \%$ dos entrevistados. É interessante ressaltar que a função do Fórum é de ser apenas um espaço de elaboração da agenda pública comunitária local, não sendo responsável pela parte operacional. A parte operacional - ou a concretização das ações discutidas pela comunidade - é efetuada pela Agência de Desenvolvimento, uma Organização da Sociedade Civil de Interesse Público, entidade sem fins lucrativos (OSCIP).

Na entrevista, 66,67\% das lideranças mencionou que já ocorreram reportagens de jornais impressos de grande circulação em Goiás sobre o turismo em São João d’ Aliança. Um caderno especial de turismo sobre São João d’ Aliança foi realizado pelo jornal “ $\mathrm{O}$ Popular” no ano de 2002. Algumas lideranças desconheciam esta informação - 33,33\%.

Outro fator questionado em entrevista foi sobre a presença de guias qualificados para o atendimento de turistas brasileiros e estrangeiros. Ocorreu um curso de guia básico no qual constatou-se que há no município cerca de cinqüenta guias de turismo treinados e certificados, mas que apenas quinze guias deste total estão exercendo este papel de forma ativa. $\mathrm{O}$ atendimento aos turistas estrangeiros conta com apenas três guias especializados e habilitados em línguas estrangeiras - resposta de 46,67\% dos líderes municipais.

Finalizando, constatou-se que a comunidade tem se organizado ou se associado com a finalidade de desenvolver o turismo no município de São João d’ Aliança, o que se verifica com a constituição do Conselho Municipal de Turismo - COMTUR e com a Associação de Guias do Município - 80\% dos entrevistados. A participação comunitária é o elemento essencial do caráter endógeno do desenvolvimento. Muito já se fez na tentativa de se destinar recursos para comunidades carentes através de programas assistencialistas. A consciência de que o turismo é uma boa oportunidade para o município é citada como um fator positivo. A maioria das reclamações das pessoas entrevistadas - de cerca de 66,67\% dos entrevistados - é que ainda há poucos agentes para concretizar a atividade turismo no município.

Com o aumento da população carente e das desigualdades sociais no Brasil e, somando-se a estes fatos a estagnação econômica nacional, verificou-se que o caráter “paternalista” do Estado não consegue suprir todas as demandas públicas que estão surgindo. O único meio de reduzir os efeitos desta realidade é auxiliar a mudança de 
comportamento das pessoas, modificando os aspectos negativos de uma cultura passiva, que tudo espera do Estado sem nada fazer por si mesmo para que a realidade se modifique.

Há muito ainda o que se fazer para que o desenvolvimento e, em específico o ecoturismo em São João d’ Aliança chegue aos patamares encontrados em Alto Paraíso, o município de maior reconhecimento ecoturístico da Chapada dos Veadeiros e seu "vizinho por natureza”.

De acordo com Matos e Miranda o desenvolvimento sustentável é entendido como um processo amplo e abrangente de mudança social e aumento das alternativas de escolhas e oportunidades da sociedade, de modo a compatibilizar, no tempo, o crescimento econômico, a eqüidade social e a preservação do meio ambiente”.

(Matos e Miranda, 2002 pág. 13)

Nesse contexto insere-se a necessidade de mobilização social para cooperação, que tem como objetivo básico, a participação ativa dos atores envolvidos no processo e que busque a eqüidade, em que a única alternativa realista consiste em proporcionar à comunidade os conhecimentos para que eles mesmos possam solucionar os seus problemas, com capacitação e tecnologias compatíveis com os recursos que realmente possuem. 


\section{CONCLUSÃO}

Durante o processo de estudos, de caracterização e de análise da região do município de São João d’Aliança, percebeu-se que a busca de soluções de curto prazo e o imediatismo de ações de políticas públicas - implementadas por vários governos - foram insuficientes para a obtenção de um modelo de desenvolvimento sustentável na localidade. A implantação de uma nova metodologia no município- a metodologia DLIS - tem comprovado que os resultados de uma proposta de desenvolvimento planejado surtem efeitos, a médio e longo prazos, quando há o comprometimento e integração de ordem institucional, da gestão compartilhada, da sensibilização, da mobilização e da participação da comunidade no planejamento de desenvolvimento municipal.

Neste processo as instituições públicas e privadas têm assumido um papel de extrema relevância. As primeiras têm assumido o papel de induzir o desenvolvimento, proporcionando efetivas condições sociais, econômicas e culturais - nas quais se destaca a manutenção do folclore local e a propagação das crenças e dos costumes regionais através de festas populares, da participação cívica da comunidade em assuntos que irão mudar o perfil do município e do fortalecimento dos laços de comprometimento - que possibilitam a permanência dessas pessoas na sua localidade de origem.

O aumento da renda proveniente do turismo e a dinamização das atividades de apoio - suprimento de matérias-primas para o artesanato, restaurantes, vestuário, aumento de vendas de farmácias, supermercados, oficinas mecânicas, padarias, entre tantos outros benefícios - começam a ser percebidos pela população com o aumento do fluxo turístico na região. O planejamento das atividades econômicas, políticas, culturais e sociais com a participação da comunidade local - reconhecendo as limitações dos recursos disponíveis permite um maior comprometimento social e, portanto, uma maior chance de serem efetivadas as decisões tomadas pela comunidade. Com a implantação de um plano municipal de ecoturismo espera-se atingir mais um elemento que possa proporcionar a melhoria da qualidade de vida da população local sem degradar o meio ambiente.

A percepção de que esta atividade é condizente com a realidade do município e de que pode constituir-se em um novo mecanismo de geração de emprego cria nesta atividade 
a "esperança” de que o ecoturismo é realmente um dos fatores que podem proporcionar o desenvolvimento sustentável nesta comunidade. As discussões da atualidade sobre o questionamento do modelo de desenvolvimento econômico vigente e a questão do equilíbrio ecológico vem resultando na assimilação do conceito de sustentabilidade. Os Fóruns urbano e rural do município de São João d’ Aliança têm destacado a relevância da estipulação do ecoturismo como uma das atividades prioritárias para o município. A ampliação da ação dos Fóruns locais foi realizada com o agrupamento deste Fóruns de várias localidades da Chapada, gerando o Acordo Cerrado, onde até as questões ambientais regionais têm sido discutidas pelas diferentes comunidades regionais de forma organizada e integrada, no intuito de fortalecerem suas opiniões e posicionamentos frente ao agentes governamentais.

O conceito de turismo considerado como a soma de relações e de serviços resultantes de um câmbio de residência temporário e voluntário permitem vislumbrar a necessidade de se obter uma rede de informações turísticas organizada que tenha por objetivo principal potencializar o ecoturismo no município de São João d’Aliança. Esta necessidade tem sido percebida pelas próprias lideranças locais que se interessam no desenvolvimento desta atividade de forma continuada, o que permite que se fale em um processo de fortalecimento do turismo municipal.

O conceito de sustentabilidade está diretamente relacionada ao elemento continuidade, à permanência da qualidade de vida e às oportunidades da sociedade ao longo do tempo - perspectiva de longo prazo. Considerando que sua base ética requer uma solidariedade social, pressupõe-se que a necessidade de subordinação da dinâmica econômica aos interesses da sociedade e às condições do meio ambiente, pode ser traduzida na solidariedade entre a geração atual e a futuras e, dentro dos diferentes segmentos da geração atual, como no caso de uma solidariedade inter-regional. Como o ecoturismo é entendido como uma modalidade de turismo sustentável - não centrado exclusivamente no bem natural - a responsabilidade ambiental - exigida por esta atividade permite a promoção da conservação do meio ambiente de forma benéfica ao envolvimento socioeconômico ativo das populações locais que dela fazem parte ou por ela são influenciadas, mesmo que forma indireta.

Uma série de fatores são determinantes para que se estabeleça o nível de potencialidade do turismo em uma localidade. A própria classificação de São João d’ 
Aliança como um município marcado pela característica de ruralidade, permite destacar seu alto potencial para o ecoturismo. A consciência das dinâmicas das atividades econômicas como o ecoturismo - localizadas em territórios rurais - reforça a necessidade de reavaliação do conceito de ruralidade. A ruralidade é um conceito de natureza territorial e não-setorial. Portanto o campo não pode ser “rotulado” apenas pela agricultura, o ecoturismo no município pode ser também inserido neste contexto de ruralidade.

Os atrativos naturais, a produção de produtos agrícolas sem agrotóxicos, a criação de animais de corte sem o uso de hormônios ou antibióticos, a culinária goiana tipicamente caseira, a presença de inúmeras plantas medicinais do cerrado, a hospitalidade dos habitantes da Chapada, as festividades culturais durante boa parte do ano, a localização privilegiada do município distante cento e cinqüenta quilômetros do terceiro aeroporto brasileiro mais movimentado no transporte de pessoas - Aeroporto Internacional de Brasília, as boas condições das rodovias que dão acesso ao município, a presença de unidades de conservação e do Patrimônio Natural da Humanidade - Parque Nacional da Chapada dos Veadeiros e a participação comunitária para a melhoria das condições turísticas do município, são alguns dos fatores que podem demonstrar a força que o ecoturismo pode tomar em São João d’ Aliança.

A Reserva da Biosfera do Cerrado Goyaz é um fator relevante para a confirmação de ser a mobilização social um forte elemento de mudança da realidade local e regional. A constituição da Reserva da Biosfera foi um fato originado a partir de discussões que ocorreram nas próprias comunidades locais, sobretudo através de organizações da sociedade civil provenientes, principalmente, da região da Chapada dos Veadeiros. O planejamento das reservas objetivando a conservação, a implantação do desenvolvimento sustentável e o aprimoramento científico condizem com fortalecimento do ecoturístico local.

A questão da mobilização social como forma de mudança social exige uma etapa preliminar de sensibilização da necessidade de organização das comunidades locais. Ao se iniciar um processo de organização ou reforçar o contexto organizacional existente, cria-se condições para que as comunidades possam identificar suas necessidades, superar seus limites, tomar suas decisões e sentir-se sujeito do processo. O processo de planejamento participativo é criado, resultando no comprometimento das pessoas com sua efetivação. Há uma relação intrínseca entre a sensibilização das pessoas e o processo de mudança social. 
As lideranças de São João d' Aliança estão percebendo uma certa mudança do município com o aumento do turismo local. Sendo o turismo uma atividade econômica geradora de emprego, as principais vantagens do desenvolvimento do turismo tem sido a geração de renda, de emprego e a melhoria da infra-estrutura turística municipal.

As leis brasileiras de turismo são consideradas muito bem elaboradas, necessitando de uma fiscalização maior dos agentes públicos para que sejam cumpridas. Com isso, a infra-estrutura turística pode ser melhorada, resultando em uma maior atração de turistas para a região.

O gerenciamento e sistematização do acesso aos atrativos turísticos do município precisam ser efetivados. A informatização e a integração dos agentes da cadeia turística precisa ser concretizada. A comunidade de São João está envolvida em um Plano Diretor de Municipalização do Turismo, fato este que contribui para se perceber a importância da mobilização social para a obtenção do desenvolvimento sustentável. Há uma escola de guias turísticos e de agentes envolvidos com o aprendizado de elaboração de projetos deste segmento socioeconômico.

Concluindo, constatou-se que a comunidade tem se organizado com a finalidade de desenvolver as potencialidades municipais. O ecoturismo é considerado um deste potenciais que deve ser trabalhado. A participação comunitária tem sido um elemento endógeno promotor do desenvolvimento municipal, mas que ainda tem muito a ser melhorado para que o ecoturismo em São João d' Aliança chegue aos patamares dos principais centros de ecoturismo do Brasil.

O desenvolvimento sustentável como processo amplo de mudança social e de aumento das alternativas de escolhas da sociedade deve compatibilizar o crescimento econômico, a eqüidade social e a preservação ambiental. Nesse contexto insere-se a necessidade de mobilização social para cooperação que tem - como objetivo básico - a participação ativa dos atores envolvidos no processo, buscando a eqüidade, em que a única alternativa realista consiste em proporcionar à comunidade os conhecimentos para que elas mesmas possam solucionar seus problemas, com capacitação e tecnologias compatíveis com os recursos que realmente possuem. No dizer de uma das lideranças locais a concretização dos "sonhos" de uma comunidade depende, do "pensar global, mas do agir local”. 


\section{REFERÊNCIAS}

Abromovay, Ricardo. Funções e Medidas da Ruralidade no Desenvolvimento Contemporâneo. Rio de Janeiro: IPEA, 2000.

ANDRADE, José Vicente de. Turismo: Fundamentos e Dimensões. 5. ed.: São Paulo: Ática, 1998.

ARRILlagA, J. I. Introdução ao Estudo do Turismo. Rio de Janeiro: Rio, 1976.

BACELAR, Tânia; BEZERRA, Maria Lucila. Experiências Recentes em Planejamento: os

Casos das Associações de Municípios do Setentrião e do Oeste do Paraná. Curitiba: Paranacidade, 1999.

BENI, Mário Carlos. Análise Estrutural do Turismo. 4. ed.: São Paulo: SENAC São Paulo, 2001.

BENSCHEIDT, Willi. Der Ortswechsel als Voraussetzung des Fremdenverkehrs. Berlim: Archiv für den Fremdenverkehrs , 1934.

BORMANN, Arthur. Die Lehre vom Fremdenverkehrs. Berlim , 1931.

Brasil. Fundação Instituto Brasileiro de Geografia e Estatística - IBGE. Censo 2000. Brasília. 2001.

BUARQUE, Sérgio C. Metodologia de Planejamento do Desenvolvimento Local e Municipal Sustentável. Brasília: IICA, 1999.

BURKART E MEDLIK. Tourism: Past, Present and Future. London: Heinemann, 1974.

Christoffoli, Ângelo Ricardo. SAntos, Carla Andrade Novaes. Silva, Carlos José Rodrigues. DiAs, Sônia Maria Kohler. Sinergia entre o Ambientalismo e o Ecoturismo. Brasília, 2002. 15p.

DE LA TORRE, Oscar. El turismo, fenómeno social. Cidade del México: Fondo de Cultura Económica, 1992. 
EHLERS, Eduardo. Agricultura Sustentável: Origens e Perspectivas de um Novo Paradigma. Guaíba, RS: Agropecuária, 1999.

Fuster, Luiz Fernandes. Teoría Y Técnica del Turismo. Madrid: Nacional, 1974. 2.Vol.

GLÜSCKMANN, Robert. Die wissenschaftliche Durchdringung des Fremdenverkehrs. Berlim: Verkehr und Büder, 1929.

GLÜSCKMANN, Robert. Fremdenverkehrskunde. Berna, 1935.

Goiás - Companhia Energética do Estado de Goiás - CELG. Balanço Energético do Estado de Goiás no ano 2000, Goiânia, 2001.

Goiás. Centro de Consultoria e Negócios - CCN, Centro de Pesquisa Econômica - CPE, Universidade Católica de Goiás - UCG. Goiás em Números, Goiânia, 1998.

Goiás. Secretaria de Infra-estrutura - Superintendência de Energia e Telecomunicações. Potencial Hidroelétrico do Estado de GOIÁs, Goiânia, 2002.

Goiás. Secretaria do Desenvolvimento e Planejamento SEPLAN. Séries Estatísticas Básicas do Estado de. Goiás, Goiânia, 2002.

Goiás. Secretaria do Meio Ambiente e dos Recursos Hídricos do Estado de Goiás Agencia Ambiental do Estado de Goiás Reserva da Biosfera do Cerrado GOYAZ, Goiânia, 2002.

Goiás. Superintendência Central de Planejamento - SEPLAN. Cenário Socioeconômico do Estado de Goiás - Perfil da Região Nordeste Goiano, Goiânia, 1996.

HADDAD, Paulo Ricardo et al. A Competitividade do Agronegócio e o Desenvolvimento Regional no Brasil. - Estudo de Clusters. Brasília, EMBRAPA, 1999.

IRVING, Marta de Azevedo; Azevedo, Júlia. Turismo: O Desafio da Sustentabilidade. São Paulo: Editora Futura, 2002

JARA, Carlos. Capital: Construindo Redes de Confiança e Solidariedade. In. Anais do II Fórum CONTAG de Cooperação Técnica. A Formação de Capital Social para o Desenvolvimento Local Sustentável. São Luís (MA), 6-8 dez.1999. 
LACKI, Polan. $\underline{O}$ que pedem os agricultores e o que podem os governos; mendigar dependência ou proporcionar emancipação? - FAO, 1999. 5p.

MATOS, Aureliano da Costa; MIRANDA Carlos. Desenvolvimento Local Sustentável no Brasil: a Experiência do IICA. Brasília: IICA, 2002.

MAtos, Aureliano da Costa; Tsuji Tetsuo; MirAndA Carlos. Seminário Internacional Desenvolvimento Rural e Agricultura Familiar. São Luís, MA: IICA, 2002.

NOVO AURÉLIO. O Novo Dicionário da Língua Portuguesa - Século XXI. Versão 3.0. Nova Fronteira, 2002.

Revista Terra: CAVALCANTI, Klester. Maior Abandonado. revista n.10, ano 11, edição 126, p. 26-33. São Paulo, outubro de 2002.

Ruschmann, Doris van de Meene. Turismo e Planejamento Sustentável: a Proteção do Meio Ambiente. Campinas, SP: Papirus, 2002.

SACHS, Ignacy. Redescoberta e Invenção do Brasil Rural. Brasília, Conselho Nacional de Desenvolvimento Rural Sustentável - CNDRS, 2002.

SERrAnO, Célia Maria de Toledo Bruhns; DE TOLEDo Heloísa Turini A. Viagens à Natureza Turismo, Cultura e Ambiente. Campinas, SP: Papirus, 1997.

SCHWINK. Die Bedeutung des Fremdenverkehrs fuer die Bayerische Wirtschaft. Berlim: Monatliche Mitteilungen des Bundes deutscher Verkehrsvereine, 1930.

STRADNER, Josef. Der Fremdenverkehrs eine volkswirtschaftliche Studie. Graz, 1930.

TRIGO, Luiz Gonzaga Godoi. Turismo Básico. 6. ed. São Paulo: SENAC São Paulo, 2002.

Vellasco, Ana Maria de Moraes Sarmento. Manual de Orientações para a Produção de Textos Acadêmicos. Apostila do Centro de Excelência em Turismo da Universidade de Brasília, julho, 2003.

World Commission on Environment and Development (WCED/CMMAD): $\underline{\text { Our Common }}$ Future. Oxford: University Press, 1987. 


\section{ANEXOS}

Anexo A - Fotos dos Atrativos Ecoturísticos de São João D’ Aliança - GO

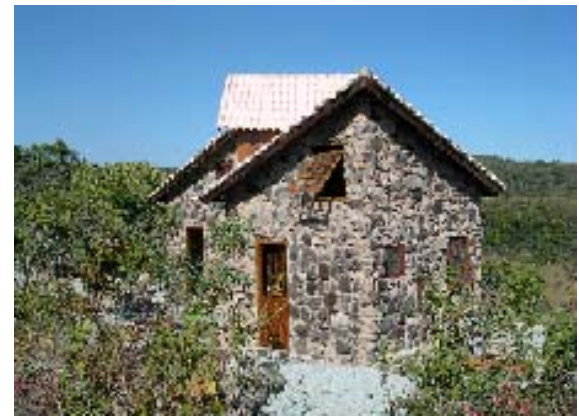

Foto 1: Condomínio Aldeia da Serra Geral

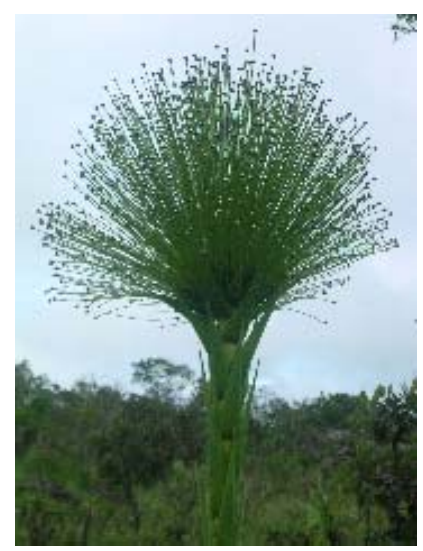

Foto 2: Chuveirinho - flor do cerrado

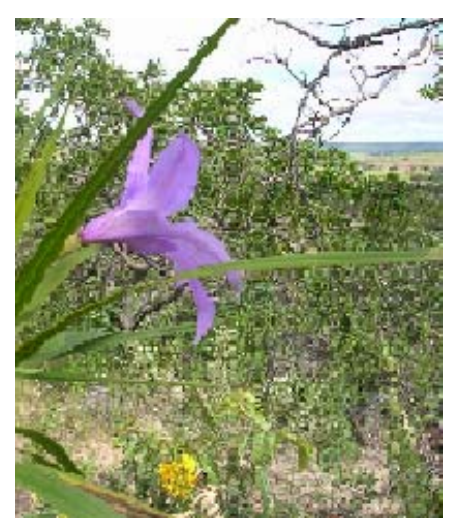

Foto 3: Canela de Ema - flor do cerrado 


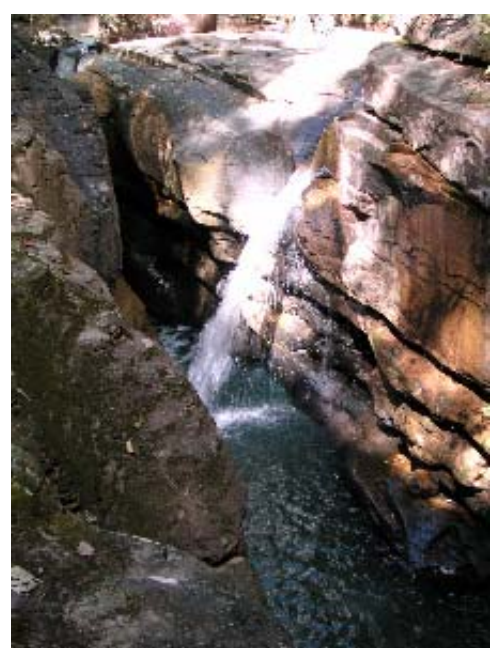

Foto 4: Cachoeira do Farias

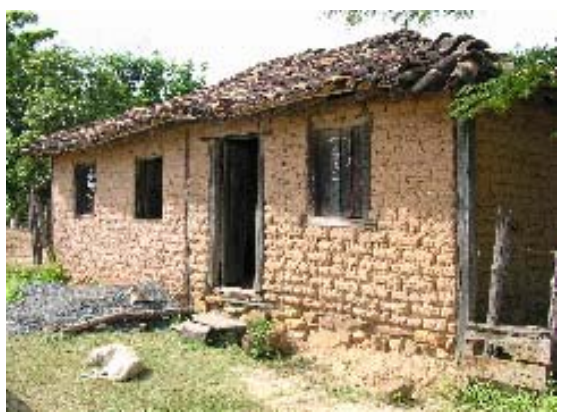

Foto 5: Casa Antiga- distrito do Forte

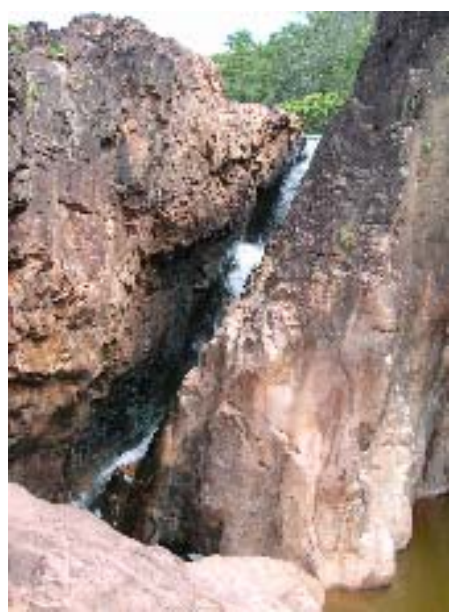

Foto 6: Cachoeirinha do Complexo do Macaco 


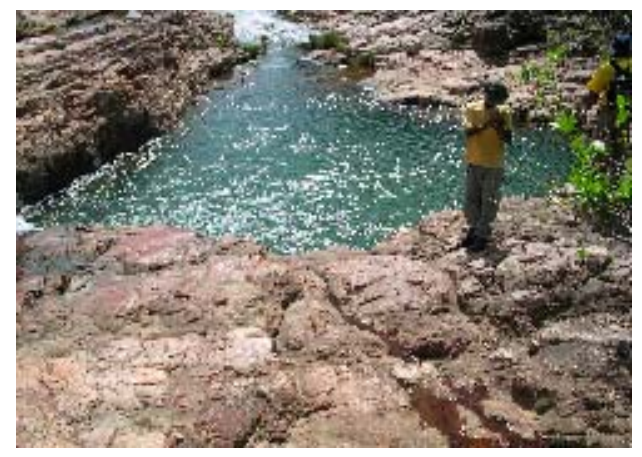

Foto 7: Poço - Macaquinho

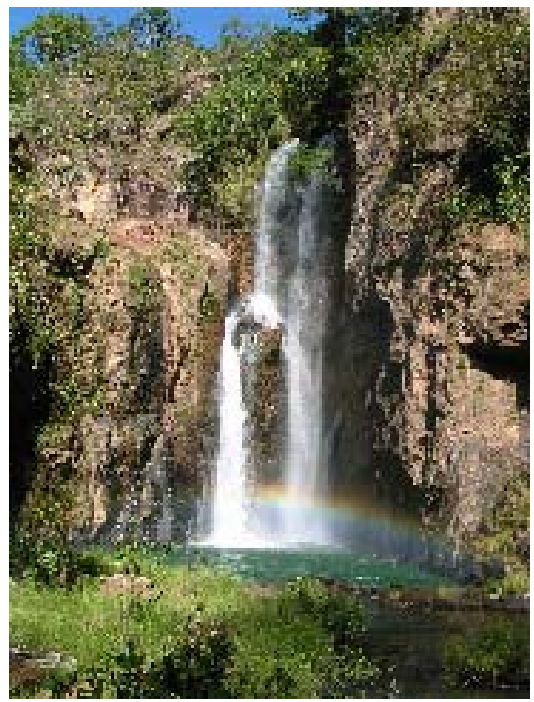

Foto 8: Cachoeira Vertical - Macaquinho

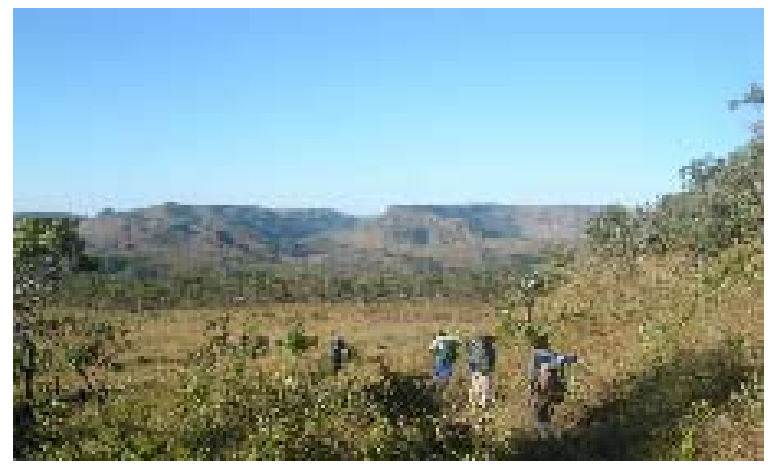

Foto 9: Caminho de Muquém - trilhas ecológicas 


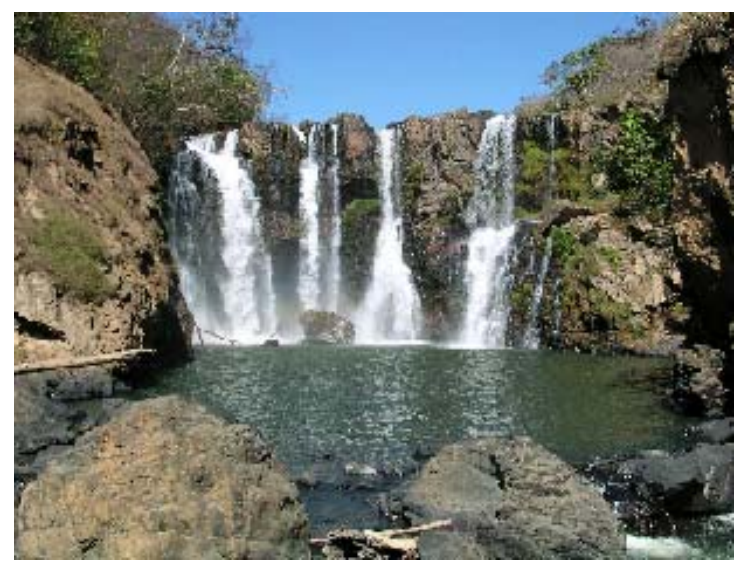

Foto 10: Cachoeira Buritizinho

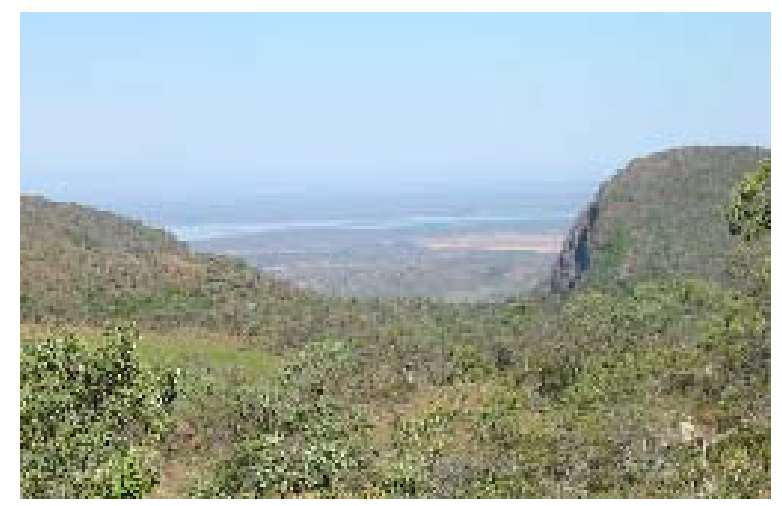

Foto 11: Vista do Vão do Paranã

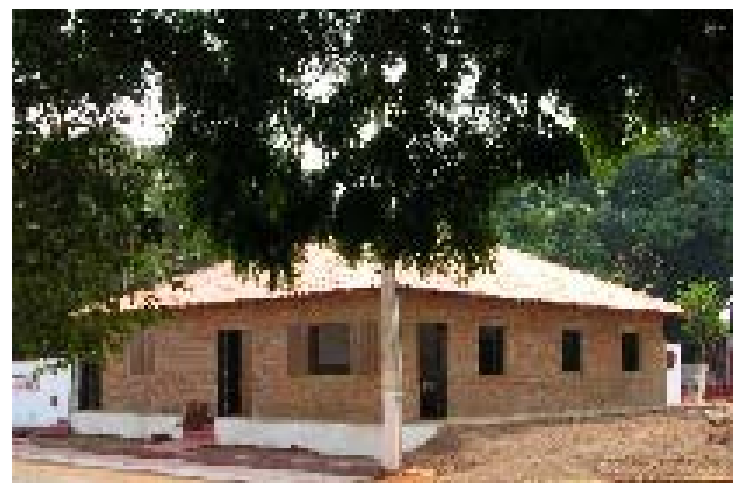

Foto 12: Casa da Capetinga e Agência de Ecoturismo Giro 


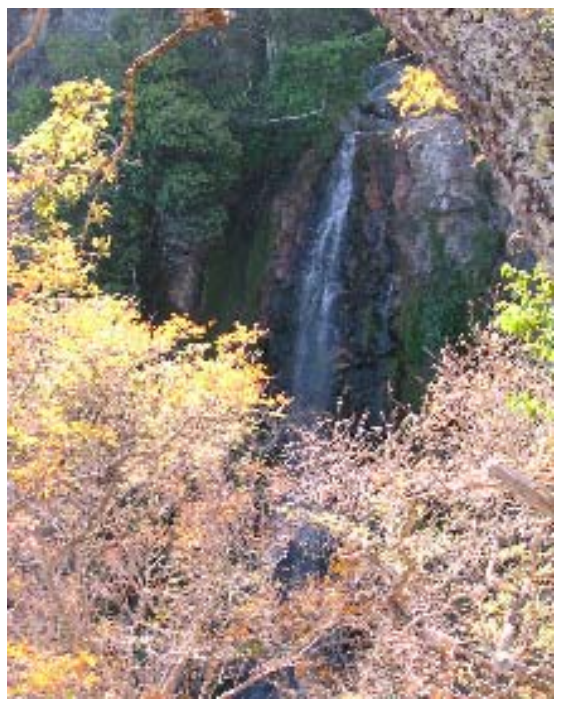

Foto 13: Vista lateral da Cachoeira da Andorinha

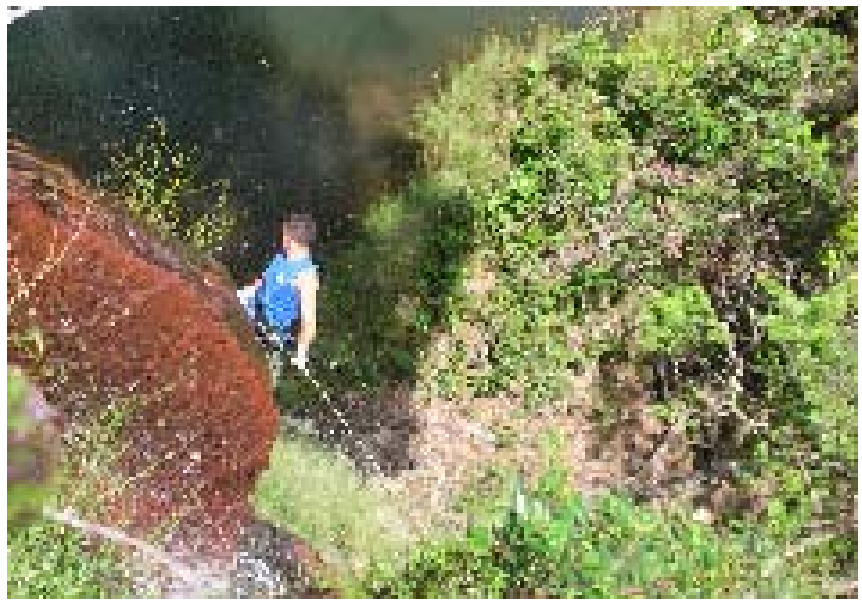

Foto 14: Vista aérea da prática de rapel na Fazenda do Pastor 


\section{Anexo B - Roteiro para Entrevista em São João d'Aliança - GO}

1) O que o (a) Sr (a) pensa a respeito de atividades de turismo no município? O Sr (a) enxerga esta atividade como uma oportunidade de emprego? Quais seriam, em seu ponto de vista, as principais vantagens do turismo para o município?

2) Com relação à conservação ambiental, o Sr (a) acha que é necessário evitar atividades econômicas degradantes ao meio ambiente?

3) O Sr(a) já ouviu falar em Ecoturismo? Seria uma atividade turística adequada ao seu município?

4) Quais são os pontos turísticos da cidade/município? Qual deles o Sr (a) mais gosta? Quais pontos do município são propícios à prática de esportes radicais (montanhismo, vôo livre, mergulho, rapel)? Já ocorreram/ocorrem competições esportivas deste tipo na região?

5) O que precisa ser feito na infra-estrutura da cidade para melhorar o atendimento ao turista? Em sua opinião, o que deve ser feito para desenvolver o turismo no município?

6) O que tem sido feito nas escolas a respeito da educação ambiental?

7) As leis municipais ajudam ou prejudicam a atividade de ecoturismo na região?

8) O município integra programas governamentais de turismo, como o Programa Nacional de Municipalização do Turismo (PNMT)?

9) Já aconteceram reportagens ou documentários de TV sobre o turismo na região?

10) Há guias na cidade capacitados a atender os turistas brasileiros? E os estrangeiros?

11) A comunidade tem se organizado ou há associações que têm como finalidade o desenvolvimento do turismo no município? 


\section{Anexo C - Prospecto de Inauguração da Sede - Acordo Cerrado}

Inauguração de nova sede da Agência Regional de Desenvolvimento Sustentável e Agência de Desenvolvimento da Capetinga. No dia do aniversário da cidade: 13 de Novembro de 2003.

CASA DA CAPETINGA Rua Wellinton de Moura 11, Praça da Matriz - São João d’Aliança - GO.

\section{Programação:}

\section{Dia 13/11}

17:30 Culto Ecumênico com banda e coral, na feira municipal;

18:30 Inauguração da Casa da Capetinga, com exposição e apresentação de teatro no salão paroquial, ao lado da casa.

20:30 Assembléia Geral Extraordinária da Agência Regional de Desenvolvimento Sustentável - ACORDO CERRADO, na Casa da Capetinga;

22:00 Show de aniversário da Cidade.

\section{Dia 14/11}

9:00 na Câmara Municipal, Seminário “INICIATIVA GOYAZ”, gestão compartilhada da Reserva da Biosfera Goyaz;

\section{Dias 15/11}

Inauguração da Base do Pastor e de outros Roteiros Turísticos.

Para maiores Informações sobre o seminário, hospedagem, roteiros turísticos:

Operadora Escola Giro Ecoturismo (62) 4381649 agema@cultura.com.br 


\section{Anexo D - Lideranças Locais}

1. Valdomiro Ramos - Presidente do Sindicato dos Produtores

2. Geraldo Bertelli - Presidente da AGEMA (Associação de Guias)

3. José Neto Fleury - Dono de Atrativo

4. Edmundo Dieter - Presidente da ACIAGA (Associação Comercial)

5. Arconide José da Silva - Presidente do Sindicato dos Trabalhadores Rurais

6. Gercina do Nascimento Nogueira - Presidente da Associação PA Águas Claras II

7. José Duides Fernandes Graças - Associação de Catireiros

8. João Damasceno - Presidente da Fundação São Vicente de Paula

9. Aparecida Chrisostomo - Pastoral da Criança

10. Marilene Batista dos Santos - ALIART (Associação de Artesões)

11. Joaquim Teles de Faria - Grupo Jovem da Igreja Católica

12. Santino Gonzaga dos Santos - Presidente da Câmara Municipal

13. Paulo César Bueno - Pré candidato a vereador

14. Nilson Teodoro Candido - Secretário de Saúde

15. Joaquim de Moura Filho - Líder no PA Mingau 


\section{GLOSSÁRIO}

1. Meio Ambiente: Espaço ou local natural que reúne seres animados e inanimados.

2. Degradação Ambiental: Processo de degeneração ou destruição do meio ambiente.

3. Ecologia: Estudo do Meio Ambiente.

4. Desequilíbrio Ecológico: Desarmonização relacional entre seres pertencentes a um mesmo meio ambiente.

5. Equilíbrio Ecológico: Processo de harmonia entre seres na natureza.

6. Sustentabilidade: Capacidade de manter um meio natural em relações de equilíbrio.

7. Impactos Ambientais: Ações que modificam a rede de relações ambientais.

8. Indústria Limpa: Conjunto de atividades econômicas que não são do tipo poluidoras, como a prestação de serviços e o desenvolvimento de tecnologias.

9. Êxodo Rural: Transferência de moradores e/ou trabalhadores do meio rural em direção aos aglomerados urbanos na busca de novas oportunidades de vida.

10. Exclusão Social: É o não exercício da cidadania na sua plenitude, alienação de direitos e deveres das pessoas em uma sociedade.

11. Subemprego: Trabalhos na economia informal, sem assinatura de carteira de trabalho, sem regularidade de exercício laboral.

12. Cidadania: Exercício pleno de direitos e deveres de uma pessoa que vive em sociedade.

13. Renda: Fator econômico que os agentes econômicos trocam em troca de outros tipos de fatores econômicos, como fator Trabalho e Capital.

14. Município: Menor divisão ou geopolítica territorial encontrada em uma unidade federativa. O Brasil adota esta nomenclatura e este tipo de classificação de seu território. 
15. Mortalidade infantil: número de crianças mortas ao nascer ou até completar 4 anos de vida.

16. Política Municipal de Ecoturismo: Conjunto de diretrizes e processo de tomada de decisões em um município que focalizam as questões de sustentabilidade do turismo.

17. Índice de Desenvolvimento Humano: Classificação do grau de desenvolvimento de uma localidade que tem como elementos de cálculo relevantes a média de renda, escolaridade e longevidade de seus habitantes.

18. Fórum de DLIS: Conjunto de pessoas unidas por laços de comprometimento social que almejam alcançar o desenvolvimento de uma localidade - município, bairro, distrito que primam pela integração dos diferentes parceiros - governamentais e não governamentais - e pela sustentabilidade das ações a serem desempenhadas para que se atinja o objetivo estipulado. Pode ser urbano, membros pertencem ao aglomerado urbano, ou rural, com membros do campo, como agricultores familiares, fazendeiros, assentados.

19. Patrimônio Cultural e Turístico Municipal: Conjunto de ativos culturais e de pontos de belezas naturais e construções humanas de um município que se traduzem na alta atratividade que exercem sobre turistas e visitantes.

20. Planejamento em Ecoturismo: Conjunto de informações, idéias e ações que buscam a implantação e a continuidade do processo da modalidade de turismo que preza pela preservação cultural, educação ambiental e consciência do valor das relações homemnatureza para a continuidade da vida no planeta em harmonia.

21. Desenvolvimento Sustentável: É a compatibilização entre crescimento econômico e a preservação do meio ambiente em prol da qualidade de vida de toda uma sociedade e das futuras gerações.

22. Preservação Ambiental: Conscientização e ações humanas que resultem na conservação das condições atuais da natureza ou que melhorem tais condições, como no caso de replantio de florestas e controle da caça de animais em extinção.

23. Turismo: É a soma de relações e de serviços resultantes de um câmbio de residência temporário e voluntário motivado por razões alheias a negócios ou profissionais 
24. Holística: Teoria segundo a qual o homem é um todo indivisível, e que não pode ser explicado pelos seus distintos componentes (físico, psicológico ou psíquico), considerados separadamente; holística.

25. Produtividade: Capacidade de aumentar a produção com uma quantidade de recursos imutável.

26. Commodities: Produtos de baixo valor agregado. Estão associados a baixa tecnologia e à economia de escala, isto é, são produzidos em grandes quantidades a baixos custos. A soja e o minério de ferro são exemplos de produtos do tipo commodities.

27. Exclusão Digital: Não inserção de pessoas na chamada Era Digital, por falta de conhecimentos na área de informática motivadas pela falta de acesso a computadores

28. Capital Social: É o grau de capacidade de uma comunidade conseguir trabalhar em conjunto ou equipe. É a capacidade de cooperar e se associar de um grupo de pessoas de uma localidade em prol de um objetivo em comum.

29. Crescimento Econômico: É o aumento da produção de agregados econômicos em um território, não está associado diretamente com o conceito de distribuição de renda.

30. Cerrado: Vegetação típica de regiões de clima tropical com estações secas e chuvosas bem definidas. Possui uma grande quantidade de arbustos e vegetação rasteira, além das suas características árvores de troncos retorcidos. É da mesma família das savanas africanas.

31. Território: É definido pela identidade natural e cultural de um espaço geográfico.

32. Ecoturismo: Atividade turística que utiliza, de forma sustentável o patrimônio natural e cultural, incentiva a conservação ambiental e busca a formação de uma consciência ambientalista por meio da interpretação do ambiente, promovendo o bem-estar das populações envolvidas”.

33. Recursos Naturais Renováveis: Recursos encontrados na natureza que têm um ciclo contínuo de reprodução. Como exemplo tem-se as plantas e os animais. 
34. Recursos Naturais Não-Renováveis: Recursos encontrados na natureza que não possuem um ciclo contínuo de reprodução. Como exemplo tem-se o petróleo e demais minérios.

35. Ecossistemas: Conjunto dos relacionamentos mútuos entre determinado meio ambiente e a flora, a fauna e os microrganismos que nele habitam, e que incluem os fatores de equilíbrio geológico, atmosférico, meteorológico e biológico; biogeocenose.

36. Antropológico: Designação comum a diferentes ciências ou disciplinas cujas finalidades são descrever o ser humano e analisá-lo com base nas características biológicas (v. antropologia biológica) e socioculturais (v. antropologia cultural) dos diversos grupos em que se distribui, dando ênfase às diferenças e variações entre esses grupos.

37. Educação Ambiental: Processo de aprendizagem do respeito e conscientização da importância da questão da preservação do meio ambiente.

38. Trade Ecoturístico: Conjunto de elementos que compõem a cadeia de negócios do ramo Ecoturismo.

39. Ambientalismo: Movimento de idéias radicais de proteção ao ambiente natural que se transformam em possibilidades concretas de preservação através das regras de conduta dos seus ativistas, ocorrendo de fato uma interpolação entre teoria e ação prática na proteção do meio ambiente

40. Simbiose: Associação entre dois seres vivos que vivem em comum.

41. Nordeste Goiano: Região composta de vinte municípios que se encontram localizados no extremo nordeste do Estado de Goiás.

42. Chapada dos Veadeiros: microrregião composta de oito municípios que se encontram localizados na parte ocidental da região do Nordeste Goiano.

43. Vão do Paranã: microrregião composta de doze municípios que se encontram localizados na parte oriental da região do Nordeste Goiano. 
44. Rapel: É uma modalidade esportiva radical, a qual consiste na descida de obstáculos da grande altitude através da utilização de cordas e equipamentos apropriados. Pode ser praticado em prédios, cachoeiras, montanhas, pontes, entre outros.

45. Rafting: Esporte radical no qual se utiliza botes e equipamentos de segurança apropriados para descer corredeiras de rios ou riachos.

46. Reserva Ecológica: Espaço físico onde é proibida a exploração econômica, a qual preza pela preservação as espécies da fauna e flora locais e que está, geralmente , sob o domínio público.

47. Reserva Particular do Patrimônio Natural: Espaço físico de propriedade particular onde é proibida a exploração econômica, e que preza pela preservação das naturais locais. Segue toda uma legislação ambiental específica.

48. Hotel-fazenda: Estabelecimento hoteleiro, com toda a infra-estrutura de conforto, restaurante, atividades que está inserido dentro de uma propriedade da zona rural.

49. Ruralidade: É um conceito de natureza territorial e não-setorial. O campo não está limitado apenas por atividades agropecuárias.

50. Gastronomia Regional: Conhecimento teórico e/ou prático acerca de tudo que diz respeito à arte culinária de uma região, às refeições apuradas, aos prazeres da mesa. Conjunto de comidas típicas de uma região ou localidade que expressam certos hábitos e o modo de vida das populações de um determinado espaço territorial.

51. Barú: Fruto típico do cerrado que possui uma casca extremamente dura, encontrando-se dentre pelo menos três castanhas que são até três vezes maiores que um amendoim.

52. Pequi: Fruto típico do cerrado de coloração amarela, polpa “carnuda” e de forte aroma. Possui uma característica peculiar, deve ser degustado com cautela. Há a presença de milhares de micro espinhos abaixo da polpa amarela “carnuda”

53. Cadeia Produtiva: Conjunto de agentes que atuam em um ramo de negócios interligados, onde cada agente é responsável por uma das várias etapas da elaboração total de um produto. 
54. Hectares: Unidade de medida agrária, equivalente a cem ares ou um hectômetro quadrado. Seu símbolo é "há”.

55. Módulo Fiscal: Tipo de classificação de imóveis rurais adotada no Brasil. Classifica a pequena propriedade naquela que possua até quatro módulos fiscais. Com área acima de quatro e até quinze módulos fiscais, o imóvel rural é classificado como média propriedade. Qualquer imóvel rural acima de quinze módulos fiscais é classificado como grande propriedade. Obedece as normas do Estatuto da Terra - Lei 4.504/64.

56. Microrregião: Subdivisão de uma região natural

57. Região: Território que se distingue dos demais por possuir características (clima, produção, etc.) próprias.

58. Hospitalidade: Capacidade de realizar o ato de receber bem em casa terceiros que não vivem na residência forma permanente.

59. Densidade Demográfica: Número médio de habitantes que ocupam uma determinada extensão de espaço físico ou geográfico. Geralmente utiliza-se a medida de unidade $\mathrm{hab} / \mathrm{Km}^{2}$.

60. Megawatt: Unidade de medida de potência da energia elétrica correspondente a 1.000.000 de Watts. Seu símbolo é MW. Sendo o Megawatt/hora (MW/h) equivalente ao consumo de mil watts em uma hora. Um Megawatt/hora corresponde a 860.000.000 quilo calorias (Kcal).

61. Telecentros: Unidades físicas dotadas de microcomputadores, de corpo docente e de acesso à Internet que tem o intuito de reduzir o fenômeno de exclusão digital entre as comunidades carentes dos municípios brasileiros. É disponibilizada pelo programa Comunidade Ativa do Governo Federal.

62. Congado: Festa folclórica de cunhos religioso que ocorre no interior de Goiás, homenageando a Nossa Senhora do Rosário. É realizada no dia 23 de Julho.

63. Catira: Dança rural, em fileiras opostas e cantada, e cujo nome indica origem tupi, mas que coreograficamente se mostra muito influenciada pelos processos africanos de dançar. 
64. Reserva da Biosfera do Cerrado - Título cedido pela ONU para o bioma Cerrado, reconhecido pela importância de sua biodiversidade para o planeta.

65. Kalungas: Povos de raça negra remanescente de Quilombos encontrados no Nordeste Goiano - Cavalcante, Teresina de Goiás e Monte Alegre de Goiás - foram descobertos por uma antropóloga em 1988. Têm uma série de hábitos peculiares e um forte “espírito comunitário”

66. Fitofisionomia: Flora típica de uma região ou o Aspecto da vegetação de um determinado lugar.

67. Sítio Histórico: Local onde se encontram povos e culturas de relevância para a Cultura Nacional.

68. Quilombos: Esconderijo, aldeia, cidade ou conjunto de povoações em que se abrigavam escravos fugidos.

69. Pontos Turísticos: Localidades que exercem a atratividade de turistas para conhecer ou contemplar por diversos motivos, como cultural, histórico, arquitetônico, entre outros.

70. Biodiversidade: A existência, numa dada região, de uma grande variedade de espécies, ou de outras categorias taxonômicas de plantas ou de animais.

71. Consórcios Intermunicipais: Ajuntamento de municípios em prol de algum benefício para uma determinada região. É um dos requisitos do Governo Federal para a obtenção da prioridade em relação a municípios que reivindicam isoladamente determinados tipos de investimentos.

72. Cajuzinho: Espécie de caju do cerrado. É mais ácido, o que o torna mais apropriado para a preparação de sucos.

73. Turismo Científico: Modalidade de turismo voltado para pesquisas das mais diversas áreas do conhecimento que atendem

74. Cannoeing: Modalidade de esporte que utiliza-se de barcos com remo para se percorrer rios, riachos e lagos, entre outros

75. Bike: Modalidade esportiva que inclui a disputa de bicicletas em terrenos irregulares. 